\title{
Peter Thiergen
}

\section{Lavreckij \\ als "Potenzierter Bauer"}

\section{Zu Ideologie und Bildsprache in I. S. Turgenevs Roman "Das Adelsnest"}

Verlag Otto Sagner München · Berlin · Washington D.C.

Digitalisiert im Rahmen der Kooperation mit dem DFG-Projekt „Digi20“

der Bayerischen Staatsbibliothek, München. OCR-Bearbeitung und Erstellung des eBooks durch den Verlag Otto Sagner:

http://verlag.kubon-sagner.de

() bei Verlag Otto Sagner. Eine Verwertung oder Weitergabe der Texte und Abbildungen, insbesondere durch Vervielfältigung, ist ohne vorherige schriftliche Genehmigung des Verlages unzulässig. 
Die Druckvorlage wurde erstellt von

Steffi Kutschke, unter Mithilfe von Olga Sternadel

\section{Bayerische} Staatsbibliothek Münctie.i

\section{ISBN 3-87690-426-9}

(C)

by Verlag Otto Sagner, München 1989.

Abteilung der Firma Kubon und Sagner,

Buchexport/import $\mathrm{GmbH}$ München

Offsetdruck: Kurt Urlaub, Bamberg 


\section{Vorträge und Abhandlungen \\ zur \\ Slavistik}

herausgegeben von Peter Thiergen (Bamberg)

\section{Band 13}

\section{9}

VERLAG OTTO SAGNER * MÜNCHEN 


\section{Peter Brang}

zum 65. Geburtstag 


\section{LAVRECKIJ \\ ALS "POTENZIERTER BAUER"}

\section{ZU IDEOLOGIE UND BILDSPRACHE \\ IN I.S.TURGENEVS ROMAN}

\section{DAS ADELSNEST}

(Turgenev-Studien VI)

von

Peter Thiergen 
$y_{1}$

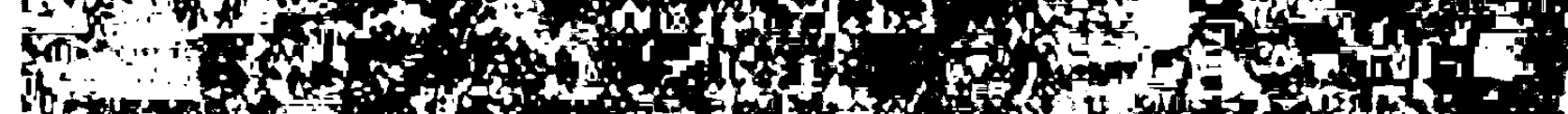

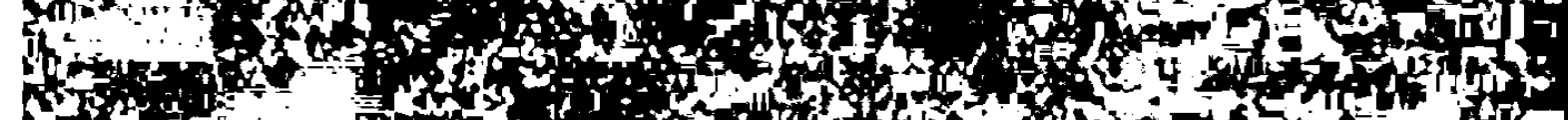

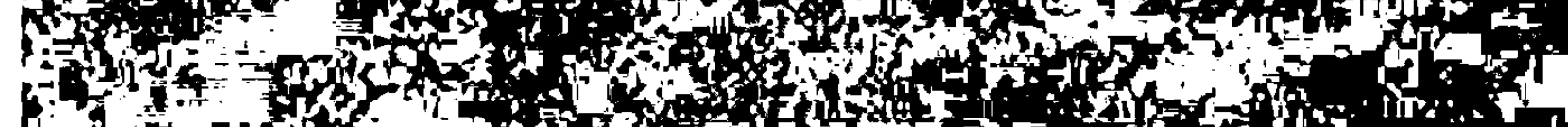

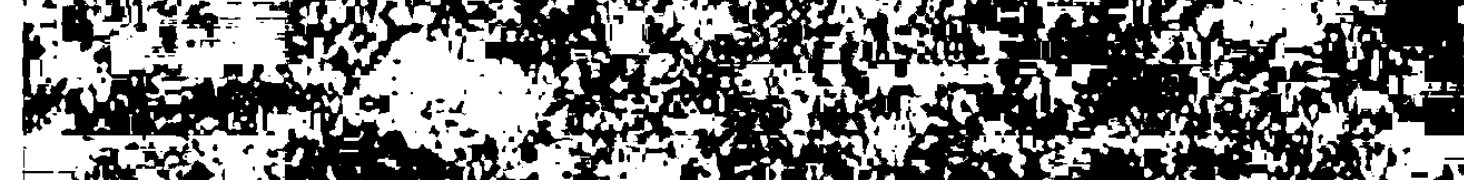

(3)

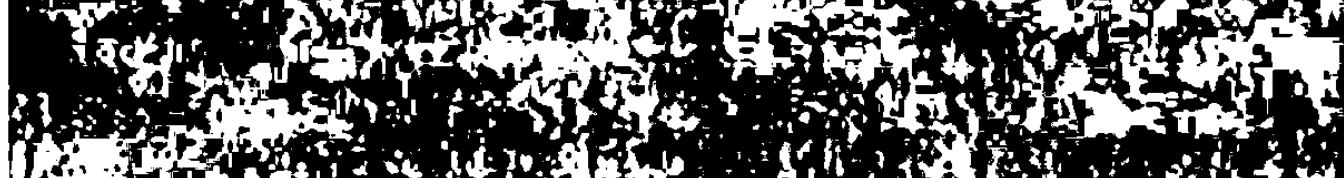

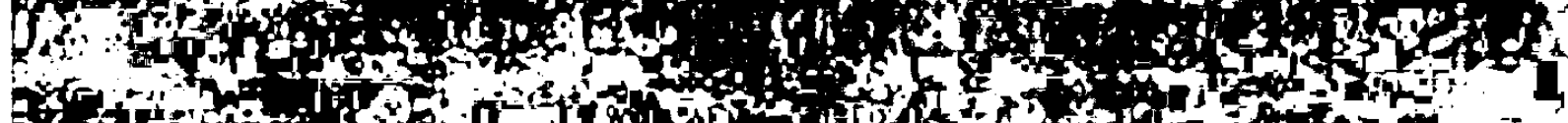
af

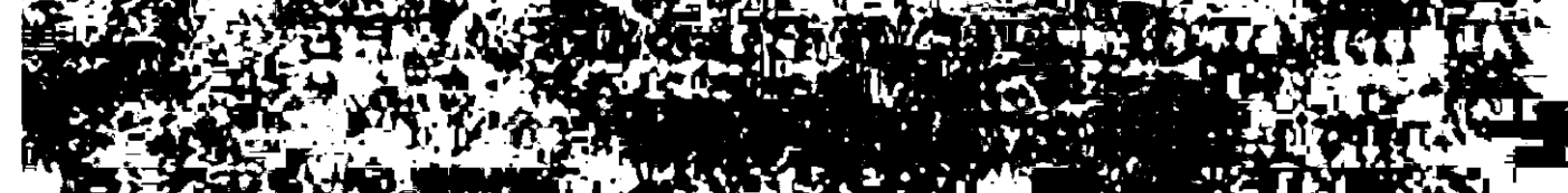
ond

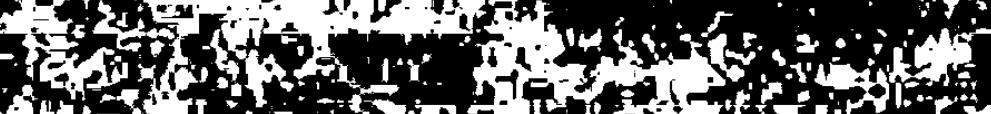

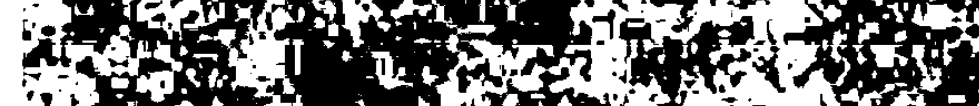
int 8 -

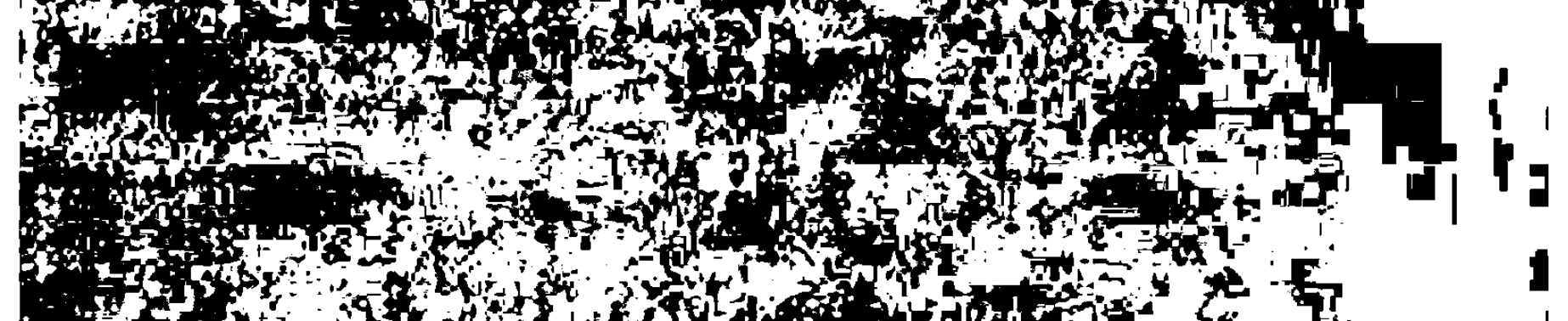

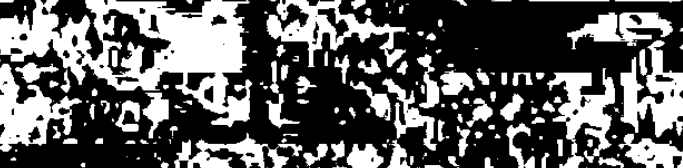

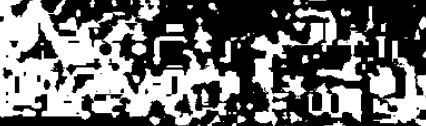

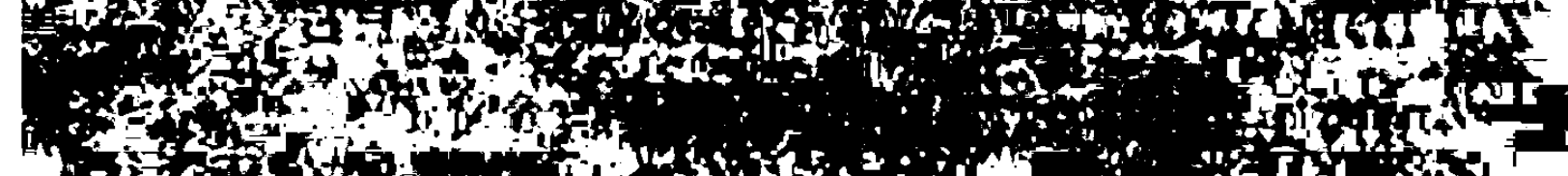

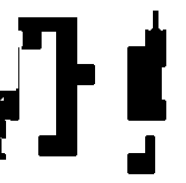

II tritis in artoris

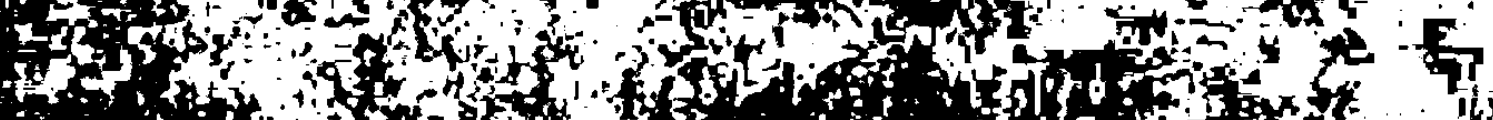
As

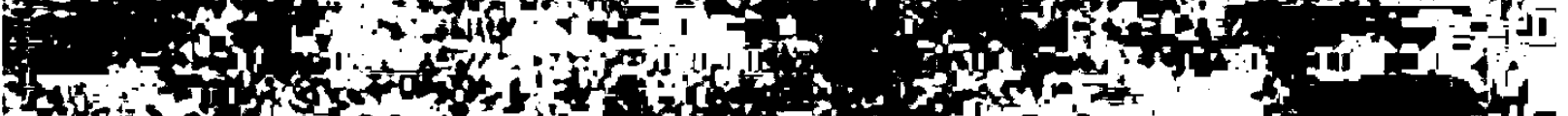
(5) ton 7 -

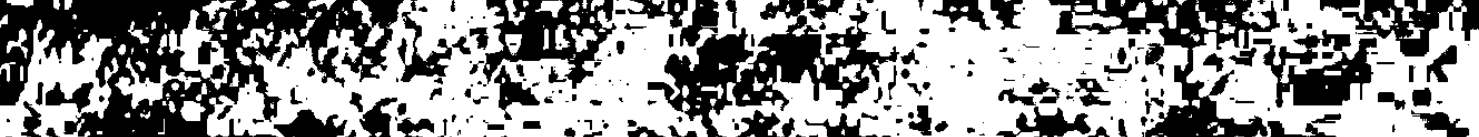

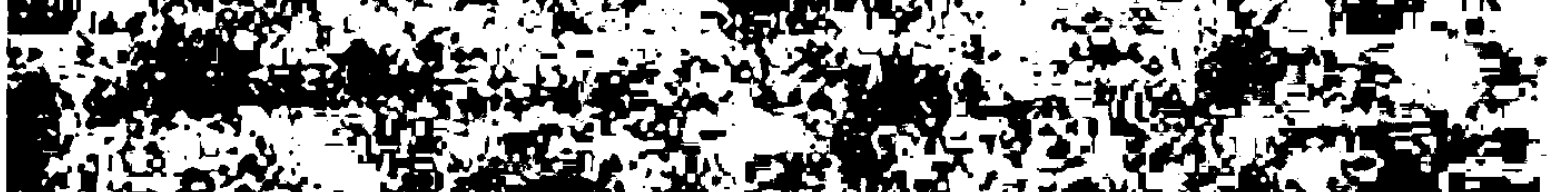
1.

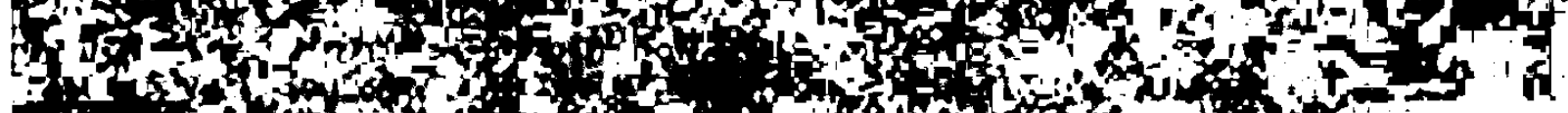

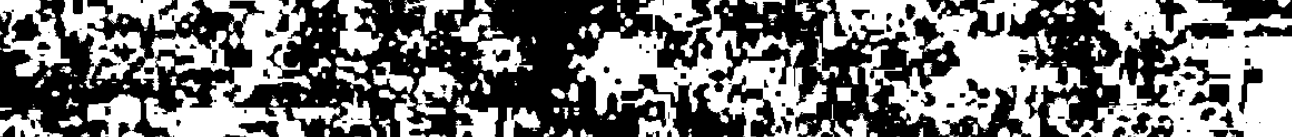

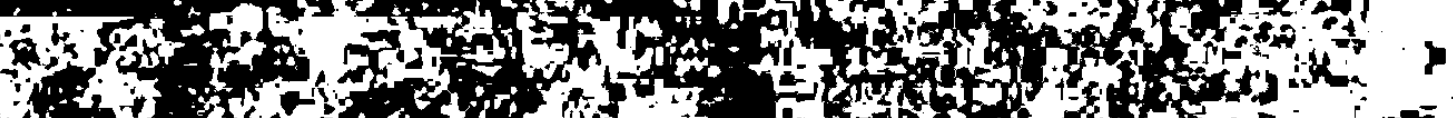
as 


\section{Inhaltsverzeichnis}

\section{Einleitung}

Turgenevs Abhandlungen zum Adels- und Bauernstand

Riehl - Bezobrazov - Turgenev

Der "potenzierte Bauer"

Liza

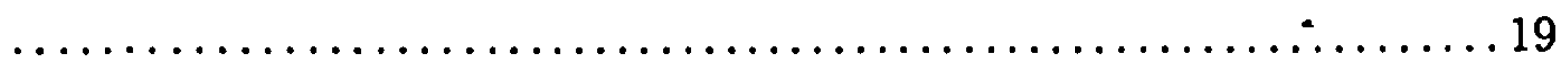

Die "Petersburger Pariser"

Wider die "Weisheit des XVIII. Jahrhunderts"

Schluß 


\section{Literaturverzeichnis}

Anhang:

M. N. Katkov

A. S. Chomjakov

P. V. Annenkov

I. S. Turgenev

V. P. Bezobrazov 


\section{Einleitung}

Der Roman Das Adelsnest (1859) ist, obwohl er zu Turgenevs bedeutemdsten Leistungen gehört, im deutschsprachigen Raum lange Zeit ohne gebührende Beachtung geblieben. Schon Eugen Zabel und Ernst Borkcwsky behandelten das Werk in ihren Turgenev-Monographien nur am R.ande, mit wenig Sinn für die historische Botschaft und poetische Texturr. Für Zabel ist der Roman "eine Liebesgeschichte mit dem gewöhnllichen traurigen Ausgange" , und für Borkowsky stellt er einen "Erziehumgsroman" dar, der in "das Gefühl tiefer Trauer um die entschwundene .Jugend" münde ${ }^{2}$. Der Bezug zu aktuellen Zeitfragen und die literarische' Gestaltung bleiben unerörtert. Für Jahrzehnte waren deutsche Leser auf Literaturgeschichten, Nachworte zu Übersetzungen, Lexikonartikel und vereinzelte Buchkapitel zu Spezialthemen angewiesen, um sich wenigstens summarisch, populärwissenschaftlich oder in Teilaspek$t_{t \alpha}$ informieren zu können ${ }^{3}$. Diesem unbefriedigenden Zustand hat erst Peter Brang mit seinem Turgenev-Buch von 1977 abgeholfen, das neben exiner eindringenden Analyse des Romans auch dessen historischen Kontrext und Bezüge zu Turgenevs Biographie behandelt ${ }^{4}$. Mit Recht weist Brang darauf hin, daB zwischen Turgenev und seinem Haupthelden Lavreckij eine besondere "Nähe" bestehe und daß im Adelsnest die "Verbindung 2 wischen der intim-psychologischen und der gesellschaftlich-weltanschaulichen Problematik" besonders harmonisch gelöst sei. Wir wollen dieses Urteil im folgenden vertiefen, indem wir vor allem über 'die "gesellschaftlich-weltanschauliche Problematik" und über den Zentr:alhelden Lavreckij weiteres Verständnis des Romans zu gewinnen suche!n.

D'vorjanskoe gnezdo ist zwischen 1856 und 1858 konzipiert und niederrgeschrieben worden. Die intensivste Arbeit und vorläufige Endfassumg des Textes erfolgten in der zweiten Jahreshälfte 1858 auf Turgenevs Landgut Spasskoe, nachdem Turgenev im Juni aus Westeuropıa nach Rußland zurückgekehrt war. In der Januarnummer des Sovre:mennik 1859 folgte die Erstpublikation ${ }^{5}$. Damit fällt die Entste-

1 :Zabel 1884, S. 115.

2 Borkowsky 1903, S. 131 und 132.

3 Besonders verdienstvoll ist die Untersuchung von Nierle 1969.

4 Brang 1977, vor allem S. 25 ff., 87-93 und 117 ff. Siehe zuletzt auch Dudek 1988.

5 Zur genauen Textgeschichte vgl. I.S.Turgenev, Polnoe sobranie soclnenij i pisem, 
hung des Romans in die stürmischen, hoffnungsvollen Reformjahre zu Beginn der Regierungszeit Alexanders II. (1855-1881). Kernstück der Reformen sollte die Aufhebung der Leibeigenschaft sein (die 1861 tatsächlich durchgeführt wurde). Das bedeutete, daß es nach 1855 um die Zukunft des russischen Adels ging und seine Rolle in der Gesellschaft neu definiert werden mußte. Selbstbesinnung und Selbstprognose des Adels gehörten zwischen 1856 und 1861 zu den drängendsten russischen Gegenwartsthemen. Turgenev als Angehöriger der Adelsklasse war davon unmittelbar betroffen.

Die folgenden Erörterungen gehen davon aus, daß Turgenev im Adelsnest a) einen aktuellen Beitrag zur Selbstdefinition des russischen Adels leistet, b) sich dabei in Ubereinstimmung mit Thesen des deutschen Gesellschaftstheoretikers Wilhelm Heinrich Riehl befindet und c) den Gehalt seiner Botschaft durch adäquate Motiv- und Bildwahl poetisch sichtbar macht. Gerade in der Einheit von gedanklicher Abstraktion und poetischer Anschauung besteht der literarische Rang von Dvorjanskoe gnezdo.

\section{Turgenevs Abhandlungen zum Adels- und Bauernstand}

Turgenev hat früh die Ansicht vertreten, daß Adels- und Bauernstand Rußlands in einer Art Schicksalsgemeinschaft verbunden seien. Schon 1842 verfaßte er als Beamter des russischen Innenministeriums eine Abhandlung mit dem Titel Einige Bemerkungen über die russisehe Wirtschaft und über den russischen Bauern ${ }^{6}$. Er legte dar, daß Landbearbeiter (= die Bauern) und Landbesitzer (= der Adel) trotz der Leibeigenschaft durch Geschichte und Volksgemeinschaft "Brüder" seien, von deren Zusammengehen die "Zukunft Rußlands" abhänge. Den Gutsbesitzern trug er auf: "Das bisherige, für Bauern und Besitzer gleichermaßen nutzlose Dahinleben der Adligen auf ihren Gütern wird einer positiven Tätigkeit weichen müssen, dem Wunsch und Vermögen, den Zustand der Wirtschaft zu verbessern... Unsere Brüder, die russischen

28 Bde., AN SSSR, Moskva-Leningrad 1960-1968, Socinenija Bd. 7, 1964, S. 448 ff.. besonders $457 \mathrm{ff}$. Alle weiteren Turgenev-Zitate folgen, soweit nicht anders vermerkt. dieser Ausgabe. Siehe auch Granjard 1960, S. 208-233.

6 Neskol'ko zamecanij o russkom chozjajstve i o russkom krest'janine, in: Socinenija Bd. 1, S. 459-472; dazu Kommentar S. 629 ff. 
Bauern, haben das Recht, von ihren gebildeteren Landsleuten eine tätige, eifrige Hilfe zu erwarten..."?

Nach dem Auftakt 1842 hat Turgenev weitere publizistische Beiträge zur Bauern- und Adelsfrage geschrieben. Unter anderem stellte er Louis Viardot diesbezügliche Materialien zur Verfügung, die dieser in eigenen Publikationen der Jahre 1846 und 1857 in Frankreich verwertete ${ }^{8}$. Turgenev bezeichnete den russischen Bauern abermals als "unseren Bruder", forderte die schnellstmögliche Aufhebung der Leibeigenschaft und beklagte, daß die russischen Gutsbesitzer infolge ihres "Absentismus" (= Leben in den russischen Hauptstädten bzw. im Ausland) ein gebrochenes Verhältnis zu ihren Bauern hätten. Deshalb seien viele Adlige - obwohl mit den Bauern "eines Blutes, eines Landes und einer Religion" - augenblicklich nicht in der Lage, die Bauernbefreiung sinnvoll mitzugestalten ${ }^{9}$.

Im Jahre 1858 verfaßte Turgenev, angeregt von der offiziellen Vorbereitung der Bauernbefreiung, weitere Stellungnahmen. Im Januar entwarf er ein ausführliches Programm zur Gründung einer Zeitschrift mit dem Titel Wirtschaftsanzeiger ${ }^{10}$. Das Journal sollte als offizielles Staatsorgan die verunsicherten Adligen mit Sinn und Folgen der Bauernreform vertraut machen. Nach Ansicht Turgenevs sollte vor allem der Existenzangst und der wirtschaftlichen Inkompetenz des Adels mit gezielter Verbreitung ökonomischer Spezialkenntnisse abgeholfen werden, damit das Reformwerk nicht im Chaos ende. Für diese Aufklärungsarbeit sei vor allem die "russische Wissenschaft und russische Literatur" gefordert ${ }^{11}$.

Im gleichen Jahr, wohl im November oder Dezember 1858, beginnt Turgenev eine Fragment gebliebene Abhandlung, die erst 1967 unter

7 Ebda. S. 469 und 472.

8 Vgl. dazu Den 1968, S. 107-144. Siehe auch die zweite, verbesserte u. ergänzte Turgenev-Ausgabe in 30 Bänden, Socinenija Bd. 12, Moskva 1986, S. 516-547 und 704 ff. Hier ist der Text allerdings in der Rubrik "Dubia" abgedruckt.

$9 \mathrm{Vgl}$. Den, aaO., S. 127 und 131 f. (= 139 und 142 f.). - Turgenev hat sich spāter selbst den Vorwurf des "Absentismus" (absenteizm) gemacht: dieser sei die "tragische Seite $^{»}$ seines Schriftstellerdaseins gewesen, vgl. Pis'ma Bd. 12/1, 1966, S. 113 und 116; dazu Brang 1977, S. 112.

10 Zapiska ob izdanii zurnala "Chozjajstvennyj ukazatel" " in: Socinenuja Bd. 15,1968 , S. 235-244 und $423 \mathrm{ff}$.

11 Ebda. S. 237. Nebenbei sei bemerkt, daB Turgenev als wichtigste Voraussetzung für das Gelingen der Reform "glasnost' " ansieht, vgl. ebda. S. 238, 240, 242! Zum weiteren Schicksal der Zapiska vgl. ansonsten Zaborova 1982, S. 212-216. 
dem Herausgebertitel Einige Gedanken über die gegenwärtige Bedeutung des russischen Adels veröffentlicht worden ist ${ }^{12}$. Turgenev nimmt die bevorstehende Bauernbefreiung zum Anlaß, die Funktion des Adels für die russische Gesellschaft zu bestimmen und näher auf Unterschiede zum Adelsstand Westeuropas einzugehen. Seiner Ansicht nach bildet der russische Adel zusammen mit allen anderen Ständen, vor allem den Bauern, eine große staatsorientierte "Familie", im Unterschied zum Adel des Westens, der als abgeschlossene Erobererkaste entstanden sei und anstelle von friedlichen Landgütern befestigte Burgen geschaffen habe. Das Urprinzip der russischen Stände bestehe im "Dienst am Lande" (služenie zemle), wobei die Bauern mit dem "Pflug", die Adligen dagegen vor allem "der Sache der Aufklärung und Bildung" dienten. Darin offenbare sich eine zusätzliche Differenz zu Westeuropa, da dessen Bildungsschicht gerade nicht vom Adel geprägt sei. Über das Dienstprinzip hinaus sieht Turgenev Adel und Bauern Rußlands durch eine weitere Parallele verbunden: beiden komme die Bezeichnung "landbesitzender Stand" zu. Die russische Gesellschaft werde jetzt endlich das herausbilden, was andere Völker schon längst erreicht hätten: "eine Klasse der Landbearbeiter, die zugleich auch die Landbesitzer sind" (klass zemledel'cev, kotorye $\mathrm{v}$ to že vremja i zemlevladel'cy) ${ }^{13}$.

"Zemledelie" bedeutet sowohl praktische Landwirtschaft wie theoretische Agronomie ${ }^{14}$. Turgenev versteht damit unter "zemledelec" einen Fachmann, der Theoretiker und Praktiker zugleich sein soll. Nach Turgenev wird es vor allem die Aufgabe des gebildeten russischen Landadels sein, diese Personalunion herzustellen. Bewältigt der Adel diese Aufgabe, wird er für die Zukunft Rußlands eine unverzichtbare, aufbauende Rolle spielen. Mit dieser Prognose bezieht Turgenev eine deutliche Gegenposition zu Dobroljubov und vor allem zu Cernyševskij, die dem russischen Adel wegen fehlender historischer Perspektiven die Daseinsberechtigung abgesprochen hatten. Übereinstimmung dagegen besteht mit A.Herzen, der ähnlich wie Turgenev die These vom "Überflüssigsein" des Adels ablehnte ${ }^{15}$.

12 Neskol'ko myslej o sovremennom značenii russkogo dvorjanstva, in: Socinenija Bd. 14, 1967, S. 299-304 und $568 \mathrm{ff}$.

13 Ebda. S. 300.

14 Vgl. Slovar' russkogo jazyka v 4 tt., 2., verb. Aufl., Bd. 1, Moskva 1981, S. 607.

15 Vgl. u.a. Herzens Aufsätze Very dangerous!!! und Lišnie ljudi i zelževiki aus den Jahren 1859/60. Zur Polemik gegen Cernysevskij vgl. Antonova 1962, S. 92-106, 
Während der Bauernbefreiung 1861 befand sich Turgenev in Paris, von wo er alle diesbezüglichen Nachrichten aus Rußland mit größter Anspannung verfolgte. Nach dem Manifest vom 19. Februar, das er einen "velikij ukaz" nennt, besucht er eine Dankesmesse und betet "unter Tränen" für den Zaren. Er will alsbald nach Rußland zurückkehren, um das Verhältnis zu seinen Bauern "endgültig in Ordnung zu bringen"16. Anderthalb Jahre später formuliert er in einem Brief an Herzen abermals, die Aufgabe des Adels bestehe darin, dem russischen Volk als "Zivilisationsbringer" zu dienen ${ }^{17}$.

\section{Riehl - Bezobrazov - Turgenev}

Mit Turgenevs oben zitierter Bemerkung zur Identität von "zemledelec" und "zemlevladelec" hat es eine besondere Bewandtnis: Sie ist schon in Turgenevs Text als Zitat kenntlich gemacht, allerdings ohne Herkunftsnachweis. Um diesen hat sich T.P.Golovanova im Kommentar der Turgenev-Ausgabe sowie in einem gesonderten Aufsatz bemüht ${ }^{18}$. Sie verweist auf V.P.Bezobrazovs Abhandlung Über Ständeinteressen - Gedanken und Notizen anläßlich der Bauernfrage (O soslovnych interesach - Mysli i zametki po povodu krest'janskogo voprosa), die 1858 in den Nummern 9-10 des Russkij Vestnik erschienen war, d.h. während Turgenevs Arbeit am Adelsnest und kurz vor der Entstehung des Aufsatzfragments zur Adelsfrage. Golovanovas Hinweis ist nicht nur zutreffend, sondern eröffnet neue Perspektiven. Als Beleg für Turgenevs Rückgriff auf Bezobrazovs Abhandlung führt Golovanova eine Textstelle an, in der sich Bezobrazov seinerseits auf W.H.Riehl bezieht! Da Golovanova dem Problem Riehl - Bezobrazov - Turgenev nicht näher nachgegangen ist, sei das an dieser Stelle nachgeholt.

Wilhelm Heinrich Riehl (1823-1897) war einer der "letzten Polyhistoren" des 19. Jahrhunderts. In zahlreichen Publikationen hat er sich zu Volks- und Landeskunde, Gesellschaftstheorie, "socialer Politik" sowie zu Kultur- und Kunstgeschichte geäußert. Zugleich war er ein bekannter Novellist und Vortragsredner. Als er in den fünfziger Jahren eine

sowie Nikitina 1987.

16 Vgl. Pis'ma Bd. 4, 1962, S. 198-214.

17 Ebda. Bd. 5, 1963, S. 51 f.; vgl. dazu auch Brang, aaO., S. 28 f.

18 Vgl. Turgenev, Socinenija Bd. 14, 1967, S. 570, sowie Golovanova 1968, S. 159/Anm. 16 . 
Berufung für Kultur- und Staatswissenschaft an die Münchner Universität erhielt und zugleich zu einem der engsten Mitarbeiter des renommierten Cotta-Verlages aufstieg, erlangte er in der deutschen Öffentlichkeit weitreichenden Einfluß. Vor allem die ersten, in zahlreichen Auflagen verbreiteten Bände seiner "Naturgeschichte des Volkes" - Die bürgerliche Gesellschaft $\left(1851,{ }^{6} 1861\right)$, Land und Leute $\left(1853,{ }^{5} 1861\right)$ und Die Familie $\left(1855,{ }^{6} 1867\right)$ - erregten Aufsehen. Riehl propagierte in provokantem Gegensatz zur traditionellen Staats- und Diplomatiegeschichte die neuen Fächer der Volkskunde, Kulturhistorie und Gesellschaftslehre. Er stellte Struktur- neben Ereignisgeschichte, beachtete neben dem "Juristenrecht" das "Volksrecht" und bevorzugte statt deduktiver Theoriebildung induktiv angelegte Empirie. Ethnographische Materialien und sittengeschichtliche Details waren die Stoffgrundlage seiner Arbeiten. Allerdings hat Riehl seine neuen Ansätze durch einen dezidierten sozialpolitischen Konservatismus bei deutschen Kritikern bald in Mißkredit gebracht. Er idealisierte den Ständestaat und verkannte die Dynamik des Industriezeitalters. Seine Hoffnungen richtete er auf Adel und Bauerntum als die "Mächte des socialen Beharrens", sein Mißtrauen gegen Bürgertum und Proletariat als die "Mächte der socialen Bewegung". Geradezu mit Abscheu betrachtete er das sogenannte "Geistesproletariat". Das alles machte ihn $\mathrm{zu}$ einer ebenso interessanten wie umstrittenen Figur, und sowohl konservative Historiker wie H.v.Treitschke als auch progressive Theoretiker wie F.Engels wiesen seinen Ansatz als "Dilettantismus" zurück. Dennoch brachte es Riehl in kürzester Zeit zum Volksschriftsteller, dessen Bücher nicht nur allenthalben rezensiert, sondern als "Hausbücher" tatsächlich gelesen wurden ${ }^{19}$.

Zur deutschen Resonanz kam sehr bald die internationale Beachtung. Seit 1852 erschienen in der Westminster Review Kurzrezensionen, und Mitte 1856 folgte ebenda eine lobende Stellungnahme von George Eliot (1819-1880), die Riehls "Naturgeschichte des Volkes" als Beweis dafür ansah, daß Sozialgeschichte auf konkreter Volksforschung basieren müsse. Eliot empfahl Riehls "bewundernswerte" Schriften als Muster für entsprechende englische Untersuchungen ${ }^{20}$.

${ }^{19} \mathrm{Zu}$ Riehls Biographie, Bedeutung und Wirkungsgeschichte vgl. Geramb 1954 sowie Thiergen 1978.

${ }^{20} \mathrm{Vgl}$. Westminster Review, New Series, July 1856, S. 51-79. Siehe dazu Thiergen 1978, S. $14 \mathrm{f}$. und 81 , sowie Lepenies 1985, S. $239 \mathrm{ff}$. 
Besondere Wirkung erzielte Riehl in Rußland, wo die Reformbestrebungen ab 1856 seine Aufnahme begünstigten ${ }^{21}$. Er galt als Musterbeispiel jener beschreibenden Sozial- und Volksforschung, die man zur Bestandsaufnahme der Gesellschaft und Durchführung der Bauernreform für erforderlich hielt. Zentren des entsprechenden Riehl-Interesses waren zunächst M.N.Katkovs Russkij Vestnik und der Zirkel der Slavophilen, später die Zeitschrift Otečestvennye Zapiski. Zu Katkov und den Slavophilen entwickelte Turgenev seit 1858 enge Kontakte.

Katkov persönlich sorgte ab 1857 dafür, daß Riehl den russischen Lesern vorgestellt wurde. Er bezeichnete Riehls Arbeiten als "glänzende" Beispiele der Sozialgeschichte ${ }^{22}$, ließ Übersetzungen der Novellen drucken und brachte 1857-1859 eine von Bezobrazov verfaßte Artikelserie zu Riehls Hauptwerk Die Naturgeschichte des Volkes ${ }^{23}$, in der vor allem Die bürgerliche Gesellschaft sowie Land und Leute besprochen wurden. Auf den rund vierhundert (!) Druckseiten dieser Serie, die zahlreiche Zitate und Paraphrasen aus Riehls Schriften enthielten, waren die Essentialien von Riehls Lehre nachzulesen. Für Bezobrazov stand fest, daß Riehls Theorien grundsätzlich auch auf Rußland anwendbar seien ${ }^{24}$. Mit Blick auf Turgenevs Ideologie im Adelsnest sind folgende Kernpunkte hervorzuheben ${ }^{25}$ : Riehl/Bezobrazov postulieren

$\diamond$ Es gebe historisch einen gesunden und einen entarteten Adel

$\diamond$ Der "weltgeschichtliche Beruf" und die "sociale Bedeutung" des jetzigen Adels bestehe darin, durch Reform des eigenen Standes die Neuorganisation der Gesellschaft einzuleiten $(104,115)$

$\diamond$ Der Adel dürfe sich dabei nicht in "kastenmäßige Absperrung" flüchten, sondern müsse als unabhängiger Stand durch moralische, kulturelle und ökonomische Gesundung Vorbildfunktion übernehmen $(105,108,115)$

$\diamond$ Besonders der Landadel solle den Bauern helfen, Landbesitz zu erhalten und wirtschaftlich zu modernisieren $(100,106$ f., 113, 116)

21 Hierzu ausführlich Thiergen 1978; Granjard 1966 erwähnt Riehl nicht.

$22 \mathrm{Vgl}$. unten im Anhang Katkovs Zametki.

23 Vgl. dazu Thiergen 1978, S. 36 ff. und 70-118.

24 Vgl. ebda. 91, 97, 103, 114 u.ö.

25 Die folgenden Seitenangaben in den Klammern beziehen sich auf Thiergen 1978; vgl. auch die Resumees ebda. S. 114 und 117 f.; siehe auch die Texte im Anhang. 
$\diamond$ In den Wald- und "Bauernlandschaften" sei ohnehin die Naturkraft des Volkes enthalten, nicht in den Großstädten, die als "Wasserköpfe der modernen Civilisation" Kultur- und Traditionsverfall begünstigten: das "Bauerntum ist jenes letzte historische Reservoir der Volkssäfte, aus denen sich alle Gesellschaftsklassen erneuern" $(88,91,97)$

$\diamond$ Dorfgemeinde und freie Landgüter müßten gegen "bürokratische Mechanik", "Kanzleieifer" und Zentralismus geschützt werden, ebenso das Familienbewußtsein gegen die Auflösung von Sippe und Sitte (88 f., 104 f., 113)

$\diamond$ Zentralismus, "Uebercivilisation" und Sittenverfall seien vor allem in Frankreich und besonders in Paris verbreitet (93, 98 f., 108 f., 118)

$\diamond$ Die grundsätzliche Einheit von Gutsbesitzern und Bauern beruhe darauf, daß der Adel ein potenziertes Bauerntum sei: "Der Gutsbesitzer ist in seiner gesellschaftlichen, sittlichen und wirtschaftlichen Bedeutung derselbe Landmann wie der Bauer. Die Gutsbesitzerklasse ist, wie überhaupt die Aristokratie, die höchste Entwicklungsstufe des Bauerntums. Der Gutsbesitzer ist, nach einem treffenden Ausdruck Riehls, ein potenzierter Bauer" (98). ${ }^{26}$

Bezobrazov bezieht sich mit dieser Definition auf Riehls Bürgerliche Gesellschaft, wo es im ersten Kapitel des Abschnittes über "Die Aristokratie" heißt:

\begin{abstract}
"Nun ist auch der Adel, gleich dem Bauern, ein Stück leibhaftiger Geschichte, das in die moderne Welt ragt. Als unterscheidendes Merkmal tritt jedoch hinzu, daß der Adel über den in seiner Körperschaft webenden geschichtlichen Geist sich auch objectiv Rechenschaft und Nachweis gibt, daß er sich als der Bewahrer der historischen Entwickelung der Gesellschaft wissen und erkennen muß. Er ist im eigenen Standesinteresse auf die Geschichtsforschung hingewiesen, während sich der Bauer um solche Forschung gar nicht kümmert. Der Bauer weiß nicht, wer seine Vorfahren waren, aber ihre Sitten leben in ihm.
\end{abstract}

26 Zum Originaltext im Russkij Vestnik 1858, Nr. 9-10, S. 101 siehe unten im Anbang Bezobrazov S. 31. Eben dieses Zitat bringt, wenn auch unvollständig, Golovanova (siehe oben Anm. 18). 
Der Adel kennt und findet sich in seiner socialen Geschichte und wenn es auch nur die ganz trockene Familienchronik eines Stammbaumes wäre; - der Bauer steckt in seiner Geschichte und weiß es selbst nicht. Der Adel ist aus diesem Gesichtspunkt ein Bauernthum in erhöhter Potenz /.../ Wir nannten den Adel ein potenzirtes Bauernthum, sofern wir das letztere im modernen Sinn des freien kleinen Grundbesitzes fassen. Der weiteren Anhaltspunkte zur fortgeführten Parallele bieten sich hier erstaunlich viele. In beiden Ständen ruht hauptsächlich die erhaltende, hemmende und dämmende Kraft für die Gesellschaft wie für den Staat, in dem Bürgerthum und dem vierten Stand die fortbewegende, vorwärtsdrängende. Dem Adel schwindet gleich dem Bauern der historische Boden unter den Füßen, sowie ihm die Basis des Grundbesitzes abhanden kommt. Der ächte Adel und der ächte Bauer verstehen sich auch gegenseitig am besten, kommen am leichtesten miteinander aus /.../ Das macht, sie fühlen sich wahlverwandt, sie wissen, daß ihr Interesse im Großen und Ganzen auf eines hinausläuft. Auch im geschichtlichen Verlauf läßt sich's, wie wir weiter unten sehen werden, nachweisen, daß der Edelmann dem Bauern weit näher gestanden hat als dem Bürger. Darin liegt ein bedeutsamer Fingerzeig für die Aristokratie. Wenn dieselbe ihren eigenen Vortheil wahren will, dann muß sie sich als die Schirmerin der Interessen des kleinen Grundbesitzes erweisen, die selbständig kräftige Entwickelung des Bauernthumes fördern". ${ }^{27}$

Bezobrazov führt weiterhin aus, daß Adel und Bauern in einer organischen, konservativen Ständeharmonie verbunden seien, derzufolge der russische Konservatismus auf den "natürlichsten Bedingungen des Volksilebens" beruhe:

27 Die bürgerliche Gesellschan, 3. Aufl., Stuttgart/A ugsburg 1855, S. 128 ff. (Hervorhebiung von mir, P.T.). Vgl. auch Thiergen 1978, S. 100. - Riehls Definition des Adels als "portenzirtes Bauernthum" findet sich bereits in seinem Aufsatz Die Aristokratie in ihrem socialen Berufe, in: Deuteche Vierteljahra-Schrin 1851, Heft 2, S. 152-196, ebda. $1159 \mathrm{f}$. 
"Man sieht zu Recht in der Gutsbesitzer- und Bauernklasse die beharrenden Elemente der Gesellschaft; in der städtischen Klasse und in den Proletariern die Elemente der gesellschaftlichen Bewegung. Bei uns überwiegen die ersten beiden Klassen, wie in der Wirklichkeit bei uns auch, im Volk und im Staat, der beharrende Charakter überwiegt". ${ }^{28}$

Das ist, wie leicht zu sehen, abermals in engster Anlehnung an Riehl formuliert. Der erste Teil der Bürgerlichen Gesellschaft, der Bauern und Adel behandelt, trägt die Überschrift "Die Mächte des socialen Beharrens"; der zweite Teil ist überschrieben "Die Mächte der socialen Bewegung" und stellt das Bürgertum sowie das Proletariat dar.

Aus der Tatsache, daß Rußland von allen europäischen Ländern die klarste Dominanz der "beharrenden" Stände Adel und Bauerntum aufwies, zog Bezobrazov den Schluß, Rußland werde, sobald die Leibeigenschaft beseitigt sei, ein Land des sozialen Friedens sein und eine große Zukunft haben ${ }^{29}$. Mit dieser Prognose konnte er sich ein weiteres Mal auf Riehl stützen. Riehl hatte vor allem in Land und Leute eine dezidierte Kritik Westeuropas entwickelt, das er allenthalben von großstädtischer Zivilisation, Überindustrialisierung, "ruiniertem Nervensystem" und sozialer Auflösung bedroht sah. Vor allem Italien und Frankreich besäßen nur mehr ein "ausgelebtes Volksthum", aber auch das waldarme England sei gefährdet; besser stehe Deutschland da, weil es den "freien Wald" bewahrt habe. Nur dasjenige Volk werde eine Zukunft haben, das anstelle "künstlicher" Städte und "unächter" Stände (= Bürokratie, Proletariat) das Dorf und den Wald, die Bauern und den landbesitzenden Adel unverdorben erhalte und als Fundamente des Staates betrachte. So ist es logisch, daß Riehl gerade Rußland als Macht der Zukunft beschreibt:

"Ein Volk welches noch den offenen, gemeinheitlichen Wald neben dem im Privatbesitz abgeschlossenen Felde besitzt, hat nicht bloß eine Gegenwart sondern auch noch eine Zukunft.

28 Russkij Vestnik 1858, Nr. 9-10, S. 102; siehe Anhang Bezobrazov S. 32 . Siehe auch Thiergen 1978, S. 98.

29

Vgl. Thiergen 1978 , S. 100 f. 
So ist in Rußland's undurchdringlichen Wäldern... die Zukunft des großen Slavenreiches verbürgt, während uns aus den englischen und französischen Provinzen, die gar keinen ächten Wald mehr haben, ein schon halbwegs ausgelebtes Volksthum entgegenschaut". ${ }^{30}$

Daneben sieht Riehl auch im russischen Bauerntum einen Garanten künftiger Größe, da der russische Bauer als historisch gewachsener Stand mit "corporativer Selbständigkeit" trotz der Leibeigenschaft "eine vollwichtige zukunftsreiche sociale Potenz" sei ${ }^{31}$. Dem russischen Adligen dagegen spricht Riehl diese Potenz ab, da er im "Hof- und Staatsdienste" seine Unabhängigkeit zu stark eingebüßt habe. Alles in allem fürchtet Riehl sogar, Rußlands Zukunftskraft könne Europa am Ende in einer neuen Völkerwanderung regelrecht "verschlingen" 32 .

Es liegt auf der Hand, daß Riehls Thesen auch bei den Slavophilen Anklang finden mußten. Hierfür sorgten schon die slavophile Verklärung des bäuerlichen Lebens und die Theorie vom "faulen Westen" (gniloj zapad). In den slavophilen Zeitschriften (Russkaja Beseda, Sel'skoe Blagoustrojstvo) wurden Riehl und Bezobrazovs Aufsätze wiederholt besprochen und zitiert. So war im September 1858 im Sel'skoe Blagoustrojstvo die Formel vom Gutsbesitzer als "potenziertem Bauern" nachzulesen. Samarin nannte Riehl bereits 1857 einen "westlichen Slavophilen", Chomjakov verteidigte Riehl 1858 gegen Angriffe des staatsgeschichtlich orientierten Historikers Sergej Solov'ev, und I.Aksakov brach 1860 gar zu einer Besuchsreise nach München auf! Da das Riehl-Interesse der Slavophilen an anderer Stelle ausführlich behandelt ist ${ }^{33}$, mögen diese summarischen Hinweise genügen. Festzuhalten bleibt allerdings, daß Turgenev seine alten Beziehungen zu den Slavophilen 1858 deutlich intensivierte und erklärte, er sei "mit Freude bereit, in der Russkaja Beseda mitzuarbeiten" 34. Es ist ein Gemeinplatz der Forschung, daß das Adelsnest eine gewisse Nähe zur Slavophilie besitze bzw. umgekehrt "probably Turgenev's most anti-Western work" sei ${ }^{35}$. Sogleich nach Er-

30 Land und Leute, 3. Aufl., Stuttgart/Augsburg 1856, S. 44 (Hervorhebung von mir, P.T.). Vgl dazu die entsprechenden Passagen bei Bezobrazov im Russkij Vestnik 1857, Nr. 9-10, S. 662 !

31 Die bürgerliche Gesellschaft, aaO., S. 114 und 170.

$32 \mathrm{Vgl}$. Land und Leute, aaO., S. 91 und 186. Dazu Thiergen 1978, S. $206 \mathrm{ff}$.

33 Thiergen 1978, S. 178-232. Siehe auch unten im Anbang Chomjakovs Zametka.

34 Turgenev, Pis'ma Bd. 3, 1961, S. 231 (Brief vom 30.7./11.8.1858 an V.A. Cerkass-

kij). Siebe auch ebda. S. 170, 189, 211 u.ō. sowie Golovanova 1968, S. $160 \mathrm{ff}$.

35 Schapiro 1978, S. 152. Siehe auch Brang 1977, S. 20 und 88, sowie Granjard 1966, 
scheinen des Romans schickte Turgenev ein Exemplar an S.T.Aksakov in der Hoffnung, dessen "Billigung" zu erhalten ${ }^{36}$.

Was wußte Turgenev von Riehl und den russischen Diskussionen über ihn? Sicherlich eine ganze Menge. Turgenevs Belesenheit ist sprichwörtlich. Nach Auskunft von Zeitgenossen hat er "alles gelesen, was nur zu lesen ein Mensch imstande ist" (G.de Maupassant) und hat er sich "für alles auf der Welt interessiert" (H.James) ${ }^{37}$. So hat er auch Riehl zur Kenntnis genommen. Im August 1859 teilte er P.V.Annenkov aus Courtavenel mit: "Riehl habe ich mit Genuß und mit einem Gefühl gelesen, das dem Ihren ähnlich ist, auch wenn ich ihn hier und da einen Philister schimpfte"38. Mit dieser Auskunft reagierte er auf einen Brief vom Juli 1859, in dem Annenkov geraten hatte: "Ein weiteres Buch, das über Rußland geschrieben ist, ist das bekannte Land und Leute Riehls. Lesen Sie auch dieses unbedingt. Sein Grundgedanke, eine Regierungs- und Sozialwissenschaft vom Studium der primären Eigenschaften eines jeden Stammes und Volkes... zu schaffen, ist ein russischer Gedanke... [Riehl] sagt, daß das Studium der Volksbestrebungen Konservatismus ist, die Mißachtung dieser Wissenschaft und die Errichtung der Gesellschaft nach Schreibtischvorstellungen aber dem Liberalismus angehören, und daß daher der Staat, der keine konservativen Prinzipien hat, ohne Zukunft ist..."39. Hier ist zweierlei aufschlußreich. Zunächst ist kaum anzunehmen, daß Turgenev die Schriften Riehls ausgerechnet mit nach Courtavenel genommen und auf Anraten Annenkovs sogleich gelesen hätte (zumal zwischen beiden Briefen nur drei Wochen liegen). Vielmehr legt die Stellungnahme nahe, daß die Lektüre vor längerer - aber nicht allzu langer - Zeit stattgefunden hat. Die Formulierung "mit Genuß" deutet überdies auf eine gründlichere Beschäftigung und auf Lektüre der Originaltexte hin. Zweitens ist bemerkenswert, daß Turgenev der Riehl-Auslegung Annenkovs zunächst weitgehend zustimmt: Riehl wird von beiden als Autorität der Sozialgeschichte und

S. $242 \mathrm{ff}$.

$36 \mathrm{Vgl}$. Turgenev, Pis'ma Bd. 3, 1961, S. 261.

37 I.S.Turgenev $v$ vospominanijach sovremennikov, Bd. 2, Moskva 1969, S. 275 und 332 .

38 Turgenev, Pis'ma Bd. 3, 1961, S. 333: "Rilja ja čital s naslazideniem is cuvstvom, podobnym vaśemu cuvstvu, chotja po vremenam ćestil ego filisterom" (Hervorhebung von mir, P.T.). Siehe auch I.S.Turgenev $v$ vospominanijach sovremennikov, Bd. 1, 1969, S. 293 und 295.

39 Das russische Original ist abgedruckt in: Trudy pubi. biblioteki SSSR im. Lenina, vyp. 3, 1934, S. 81-84. Siehe auch unten den Teilabdruck im Anhang. 
als Gegner der Schreibtischbürokraten anerkannt. Zugleich ist damit ein Biekenntnis zu gewissen "konservativen Prinzipien" verbunden, die aus dler Respektierung der Volkstradition resultieren. Allerdings bleibt zu be:achten, daß Turgenev den Vorwurf des Philistertums erhebt. Was er damit meint, ist nicht ganz klar. Möglicherweise kritisiert er damit Riehlis realitätsblinde Vorliebe für die "gute alte Zeit", für "Rusticität" und Bauernidyllik. Turgenev sah zwar das russische Volk (narod) als "konservator par excellence" an, warf ihm aber zugleich Materialismus, Passi vität und Kleinbürgertum vor ${ }^{40}$. Mit Bauernsentimentalität à la Riehl, Bauernsozialismus à la Herzen oder slavophiler Bauernverklärung hatte er, abgesehen von der 'slavophilen Phase' im Adelsnest, wenig im Sinn. Daß er gleichwohl eine Ständegemeinschaft von Adel und Bauern postulierte, bleibt davon unbetroffen. - Turgenev hat Riehl auch später nicht vergessen. Er erwähnte ihn neben anderen zeittypischen Publizistem im 1867 erschienenen Roman Rauch, um die geistige Atmosphäre de:s rückliegenden Jahrzehnts zu kennzeichnen (der Roman spielt im Jahre 1862$)^{41}$. Im Oktober 1862 schreibt er außerdem an Herzen, er habe sich zuletzt eifrig mit A.P.Ščapov (1830-1876) beschäftigt. Ščapov propagierte damals vehement Volks- und Gesellschaftskunde und war dabeii unter anderem von Riehl beeinflußt ${ }^{42}$.

Dıa die Riehl-Kenntnis Turgenevs evident ist, bleibt die Frage, wann die Kenntnisnahme stattgefunden hat. Von Mitte 1856 bis Mitte 1858 hielt sich Turgenev in Westeuropa auf, vor allem in Frankreich und Italien, hinzu kamen zwei Reisen nach London zu A.Herzen. In Deutschland war er nur wenige Wochen ${ }^{43}$. Im Juni 1858 kehrte er nach Rußland zurück, um das Adelsnest zu schreiben. Beim jetzigen Quellenstand ist wederr auszuschließen noch zu beweisen, daß Turgenev Riehls Schriften schom in Europa gelesen hat. Nachweisen läßt sich allerdings, daß der Russikij Vestnik auch im Ausland zu Turgenevs Lektüre gehörte. So notierte er im März 1857 in Paris: "Die Journale sind hier alle erhältlich. Das interessanteste ist der Russkij Vestnik..., der Sovremennik ist

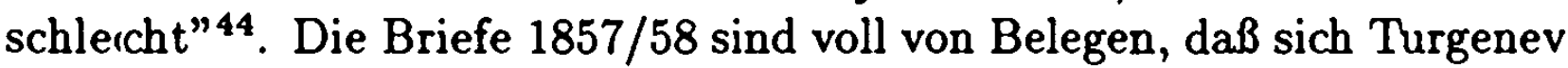

40) Vgl. Pis'ma Bd. 5, 1963, S. 52. Dazu Brang, asO., S. 28 f. - Turgenevs Kritik am "niarod" deckt sich weitgehend mit jenen Vorwürfen, die S. Solov'ev bereits 1858 gegen Riehls Überbewertung des Bauernstandes vorgebracht hatte, vgl. Thiergen 1978, S. 124 ff.

41: Vgl. Turgenev, Socinenija Bd. 9, 1965, S. 154.

42! $V_{g l}$. dazu Thiergen 1978, S. 50.

43' Vgl. Turgenev, Pis'ma Bd. 3, 1961 , S. $654 \mathrm{f}$.

44!

Ebda. S. 107. 
den Russkij Vestnik nachschicken ließ und eifrig studierte ${ }^{45}$. Im Frühjahr 1858 löste Turgenev zusammen mit anderen Autoren das “objazatel'noe soglašenie", exklusiv im Sovremennik zu publizieren. Ohnehin besaß der Russkij Vestnik damals die meisten Abonnenten ${ }^{46}$.

In diesem Zusammenhang ist wichtig, daß Turgenev seit Mitte der fünfziger Jahre mit Bezobrazov befreundet war. Vladimir Pavlovič Bezobrazov (1828-1889) stammte aus altem russischen Adel und war Absolvent von Carskoe Selo. Als äußerst belesener Spezialist für Finanz- und Wirtschaftsfragen, im weiteren Sinn für Staats- und Gesellschaftslehre, gehörte er dem russischen Finanzministerium an und war einige Zeit Hauslehrer der Zarenfamilie ${ }^{47}$. Seit 1855 führte er in Petersburg einen gelehrten Salon, zu dem u.a. Družinin, Annenkov, Tolstoj und Turgenev gehörten. Als Turgenev 1858 aus Europa zurückkehrte, wurden die Kontakte sogleich wieder aufgenommen ${ }^{48}$.

Alle Indizien sprechen nun dafür, daß Turgenevs Interesse an Riehl durch Bezobrazov und den Russkij Vestnik geweckt oder zumindest verstärkt worden ist. Bezobrazov hatte sich spätestens seit 1856 näher mit Riehl befaßt und darüber mit Katkov korrespondiert ${ }^{49}$. Ergebnis dieser Beschäftigung waren die Artikel im Russkij Vestnik, deren erste Fortsetzungen Mitte 1858 außerdem als Buchausgabe erschienen. Bezobrazov verschickte Exemplare des Buches an Freunde ${ }^{50}$, und es ist naheliegend, daß auch Turgenev bedacht wurde. Auf jeden Fall erreichte das russische Riehl-Interesse in Turgenevs Umgebung in jenem Moment einen ersten Höhepunkt, als die Hauptarbeit am Adelsnest stattfand. So kann Golovanova mit Bezug auf Bezobrazovs Riehl-Aufsätze zu Recht konstatieren, Turgenev sei mit ihnen "ohne Zweifel bekannt gewesen" 51. Hinzu kommt, daß Riehl auch in Privatgesprächen und Salondiskussionen eine erhebliche Rolle gespielt haben muß. Es kann kein

45 V gl. ebda. S. 118, 132, 152, 154, 175, 186 u.ö.

$46 \mathrm{Vgl}$. dazu Thiergen 1978, S. 74 und 160.

47 Zur Biographie vgl. ebda. S. 78 ff. Granjard 1966 erwähnt Bezobrazov nicht.

$48 \mathrm{Vgl}$. dazu näher Kijko/Ponjatovskij 1982, S. 5-8. Da sich Bezobrazov 1857 ebenfalls in Westeuropa aufhielt (u.a. in Wiesbaden und Paris), können auch dort Kontakte bestanden haben.

49 Vgl. dazu Thiergen, aaO., S. 75.

$50 \mathrm{Vgl.} \mathrm{u.a.} \mathrm{M.E.Saltykov-Śćedrin,} \mathrm{Sobranie} \mathrm{socinenij} \mathrm{v} \mathrm{dvadcati} \mathrm{tomach.} \mathrm{Bd.}$ 18/1, Moskva 1975, S. 201 und Anmerkung. Das Buch trug den Titel Materialy dlja flziologii obscestva $v$ Germanii und erschien in Katkovs Druckerei.

51 Golovanova, aaO., S. 159/Anm. 16: "Turgenev byl nesomnenno znakom s étimi stat'jami”. 
Zufall sein, daß seine Werke ab 1857 auch von Vodovozov, BestuževRjumin, Tolstoj, Družinin, Annenkov, Michajlov und anderen beachtet und zitiert worden sind ${ }^{52}$. Boris Ėjchenbaum hat für Tolstoj ausführlich dokumentiert, daß dabei auch die Ständefrage im Zentrum gestanden hat, zumal Riehl - entgegen den meisten russischen Ansichten - zwischen Adel und Bauern eine soziale Harmonie postulierte ${ }^{53}$. Nach Ėjchenbaum kann Tolstoj mit seiner Ständetheorie, Bauernrechtfertigung und Zivilisationskritik, wie sie sich in den Erzählungen seit 1857 zeige, in gewisser Weise als "učenik Rilja" - als "Schüler Riehls" - angesehen werden ${ }^{54}$.

Soweit zur Problemstellung. Die beigebrachten Fakten und dazugehörigen Erörterungen lassen es meiner Ansicht nach als sicher erscheinen, daß Turgenev während der Arbeit am Adelsnest und besonders im Sommer/Herbst 1858 intensiv mit Riehlschem Gedankengut in Berührung gekommen ist. Das läßt sich, wie wir glauben, auch am Romantext zeigen. Dieser offenbart zugleich Turgenevs hohe Kunst, die ideologische Botschaft durch ein dichtes Gewebe von Bildern, Wortfeldern und Leitmotiven in poetische Textur umzusetzen.

\section{Der "potenzierte Bauer"}

Turgenev hat seinen Helden Lavreckij mit einer ungewöhnlich langen, neun Kapitel umfassenden Vorgeschichte ausgestattet, welche u.a. den Stammbaum der Familie über mehrere Generationen zurückverfolgt, um Lavreckijs Herkunft und "Erziehung" vorzustellen. Das kann als Entsprechung zu Riehls Feststellung angesehen werden, der wahre Adel verkörpere gerade deshalb "ein Stück leibhaftiger Geschichte", weil er ein genealogisches Bewußtsein sowie Familienchroniken und Stammbäume besitze $^{55}$. Lavreckij sucht später ausdrücklich nach "alten Papieren und interessanten Dokumenten" (Kap. 21), wird aber nicht fündig. Dem

52 Vgl. A.V.Druzinin, Literaturnaja kritika, Moskva 1983, S. 309 (in der Oblomov-Rezension); M.L.Michajlov, Socinenija v trech tomach, Bd. 3, Moskva 1958, S. 380 und $383 ;$ zu Vodovozov und K.N.Bestuzev-Rjumin siehe Thiergen 1978, S. 38 ff.

53 Vgl. B.M.Éjchenbaum, Lev Tolstoj, München 1968 (Nachdruck der Ausgabe Leningrad 1928/31), Bd. 2, S. 52-109, bes. 55 ff. und 75 ff. Ejcbenbaum bringt ebda. ein langes Zitat aus Bezobrazovs Abhandlung Über Ständeinteressen (S. 56-61), darunter die Formel vom "potenzierten Bauern" (60).

54 Ebda. S. 85. Auch Tolstojs Zusammenhang mit Riehl müBte, trotz Ėjchenbaums gründlichen Vorarbeiten, noch näher untersucht werden, vgl. dazu Thiergen 1978, S. 23.

55 Vgl. Die bürgerliche Gesellschant, aaO., S. 128 f., 172, 178 f. u.ö. (Siehe auch 
Idealbild einer intakten Adelstradition entsprechen die meisten seiner Vorfahren nicht. Vielmehr zeigen sich bei einigen dieser Ahnen, vor allem beim Vater, jene Verfallserscheinungen, die Riehl für die entartete Aristokratie ausgemacht hatte: Pflege von Privilegien, "Müßiggängerei", Sittenverderbnis, Kosmopolitismus, Französisierung und Zeremonisierung der Lebensformen ${ }^{56}$. Diese Verfehlungen offenbaren zugleich die Entwicklung vom selbständig-seßhaften Landadel zum abhängigen und 'absentistischen' Hofadel, der vom "heimatlichen Nest" nach Petersburg oder Paris zieht. Besonders schlimm ist für Riehl, daß sich der depravierte Adel nicht mehr um seine Bauern kümmert. Ein gesunder Landadel ist für ihn geradezu ein "Barometer" für die "Blüthe" der Aristokratie überhaupt ${ }^{57}$. Lavreckijs Vater dagegen behandelt seine Bauern nach den Regeln der alten "barščina" (vgl. Ende Kap. 10), lebt im Ausland und kennt Rußland nur "schlecht". Diese Familiengeschichte sowie Lavreckijs heterogene, unrussische Erziehung können als literarische Veranschaulichung von Riehls Verfallsthese aufgefaßt werden.

Aus Lavreckijs Vorgeschichte resultiert seine Leidensgeschichte. Dennoch gelingt es ihm am Ende, durch "Selbsterziehung" und infolge seiner "gesunden Natur" wenigstens einen Teil der Gefährdungen zu überwinden. Das ist deshalb möglich, weil einige seiner Vorfahren von bäuerlicher Robustheit waren und weil in seinen Adern Bauernblut fließt. Sein Vater hatte Malan'ja, ein Stubenmädchen aus dem Bauernstand, geschwängert und als Zögling der französischen Aufklärung gegen den Willen der Familie auch geheiratet. Lavreckijs Eltern bilden damit ein programmatisches Paar: Der Vater war ein "Petersburger Geck", der seine Zeit zumeist in Paris und London verbrachte, die Mutter dagegen eines jener einfachen "russischen Mädchen", die ihre ganze Kraft der "Liebe" opfern (152) ${ }^{58}$. Noch vor der Geburt des Kindes von ihrem Mann verlassen, lebt sie auf dem Dorf, nunmehr weder zum Bauernnoch zum Adelsstand gehörend und gleichsam "aus dem Mutterboden gerissen" $(158)^{59}$. Als Lavreckijs Vater um 1820 nach ihrem Tod nach Rußland zurückkehrte - ein falscher "patriot" und "angloman", dessen Russisch von Gallizismen wimmelte -, führte er das "Chaos" der Guts-

oben das Zitat S. 8 f.).

56 Vgl. ebda S. 156-172 ("Der Verfall der mittelalterigen Aristokratie").

57 Ebda. S. 164.

58 In Klammern stehende Zahlenangaben des fortlaufenden Textes bezeichnen ab sofort die jeweiligen Seiten in Turgenev, Socinenija Bd. 7, 1964.

$59 \mathrm{Vgl}$. dagegen in Väter und Söhne die Verbindung von Nikolaj Kirsanov mit Fenečka, die die Standesgrenzen aufhebt. 
wirtschaft weiter und "verachtete" seine Bauern (159 f.). Vom jungen Lavreckij heißt es ausdrücklich, daß er seine Mutter "leidenschaftlich liebte", während er den Vater mied, seinen "kleinlichen Despotismus" fürchtete und den "Widerspruch zwischen Worten und Taten" im väterlichen Verhalten erkannte (160 f. und 164). Zum Großvater hingegen, den auch der Erzähler einen "einfachen Steppenbarin" nennt (149) und den Lavreckij selbst mit einem "Bauern" vergleicht (176), fühlte er sich hingezogen. Ebenso zu seiner Tante Marfa Timofeevna, die einst jahrelang in einer "einfachen Bauernhütte" auf dem Dorf gelebt und sich liebevoll der verlassenen Malan'ja angenommen hatte (126, $154 \mathrm{ff}$.).

An das 'bäuerliche' Erbgut Lavreckijs wird im Roman in leitmotivischer Häufung immer wieder erinnert. Schon vom kleinen Fedja heißt es, er sei "ungefüge gebaut und linkisch - ein echter Bauer, nach einem Ausdruck Glafira Petrovnas" (162). Der erwachsene Lavreckij hat eine kräftige Statur mit "breiten Schultern" (129, 146 u.ö.). Trotz der gescheiterten Ehe zeigt sein "rein russisches Gesicht" immer noch eine "feste, dauerhafte Kraft" (146). Bei der Entdeckung des Ehebruchs möchte er seine Frau "nach Bauernart" verprügeln (175, vgl. auch 251). Mar'ja Dmitrievna nennt ihn später einen "Bauerntölpel" (179, vgl. 200), und Varvaras Kindermädchen Justine hält ihn für einen "ungeschliffenen Bären" (270).

Mit dem Bauernmotiv ist das Steppenmotiv verbunden. Lavreckij verfügt über eine "Steppengesundheit" (146) und findet nach der Rückkehr aus Europa in der "russischen" Landschaft der "Steppenbilder", die seine Frau gerade verachtet hatte (171), wieder zu sich (183 f.). Er läßt sich auf dem Land nieder und lauscht am liebsten den Erzählungen des alten Anton über "vergangene Zeiten", da noch "undurchdringliche Wälder" und "unberührte Steppen" an die Städte heranreichten (191). Wir erinnern uns, daß auch Riehl über Rußlands "undurchdringliche Wälder" und die "endlosen Steppen des russischen Reiches" geschrieben hatte ${ }^{60}$. Wald und Dorf sind jene Natur- und Schutzzonen, die Lavreckij zugeordnet werden und ihn als 'Bauern' markieren. Dort findet er Stille, "Heimatgefühl" und Zuflucht vor städtischer Unruhe (188 ff.); dort sieht er "Kraft" und "Gesundheit" beheimatet (190). Man vergleiche dazu Riehls Ausführungen in Land und Leute:

60 Land und Leute, aaO., S. 44 und 186. 
"Man muß den Naturzuständen im Volksleben wieder gerecht werden und zwar nicht bloß in den Romanen sondern auch in der Wirklichkeit. Ich möchte, daß jede Seite dieses Buches für diesen meinen Glaubensartikel predigte... Darum nehme ich den Wald in Schutz gegen das Feld, das Land gegen die Stadt, das rohe, aber stark-und frohgemuthe jugendliche $\mathrm{Na-}$ turleben des Volkes gegen die greisenhafte Altklugheit der Civilisation..." 61

Auf dem Dorf schließlich findet Lavreckij seine wahre Aufgabe als "potenzierter Bauer". Schon in Paris hatte er sein leeres Leben beklagt, ein Buch über künstliche Bewässerung übersetzt und die Rückkehr nach Rußland ersehnt, um sich "ans Werk zu machen" (174). Auf dem Dorf erkennt er, daß nur der Erfolg hat, der die Ausdauer besitzt, "wie ein Pflüger mit dem Pflug die Furche zu ziehen" (190). Das Wort Michalevičs, er solle sich "ernsthaft um das Leben seiner Bauern kümmern" (205), läßt ihn nicht mehr los. Im Streitgespräch mit Panšin verteidigt er die "Jugend" Rußlands, weist die Einmischung bürokratischer Beamtenmaßnahmen zurück, fordert vielmehr die "Anerkennung der Volkswahrheit" und setzt sich zum Ziel: "Das Land zu pflügen... und sich bemühen, es möglichst gut zu pflügen" (232 f.). Darin sieht er "die einzige Aufgabe seiner Zukunft" (268). Im Epilog erfahren wir, daß er sein Ziel erreicht hat:

"Lavreckij hatte das Recht zufrieden zu sein: er war tatsächlich ein guter Landbesitzer geworden, hatte tatsächlich gelernt, das Land zu pflügen, und hatte sich nicht für sich allein bemüht; er hatte, so gut er konnte, das Leben seiner Bauern gesichert und gefestigt" (293).

Der Erzähler hält fest, daß es Lavreckij mit diesem auf Willenskraft und Arbeit basierenden "Umbruch" gelungen sei, ein "anständiger Mensch" zu werden (ebda.).

Lavreckij erfüllt damit die Forderungen Riehls, der Landadel solle zur "Selbstbewirthschaftung" der Güter zurückkehren und sich zur Aufgabe machen, den Bauern durch "Einführung wirthschaftlicher Verbesserungen" zu helfen. Weil der Grundbesitzer der "nächste Alliirte"

61 Ebda. S. 252. 
des Bauern sei, müsse er für diesen "in der ökonomischen und socialen Reform" vorangehen. Durch die "Wechselbeziehung" zum Bauerntum werde der Adel seinerseits "neue Kraft" schöpfen, da der Bauer "noch die meiste ursprüngliche Natur" verkörpere ${ }^{62}$. So wie der Bauer überall Respekt gewonnen habe, weil er "seinen Pflug einsetzte", so müsse auch der entwurzelte Adlige wieder zum Pfluge finden:

"Der zurückgekommene, zerfahrene, mit seinem Loose, seiner Heimath zerfallene Mann aus höheren Gesellschaftsschichten findet zuletzt Rettung und Genesung nur noch darin, - daß er Bauer wird... Wer nirgends seinen Frieden mehr finden konnte, der findet ihn im Urwald - als Bauer, und zwar nicht als faullenzender Oekonom, sondern als Bauer im Wortsinne, der Schwielen in den Händen hat und im Schweiße seines Angesichts sein saures Brod iBt. Es liegt für den Staatsmann ein deutungsschwerer Fingerzeig in dieser Thatsache, daß die abgestandenen Theile der Gesellschaft zuletzt in Bauernleben und Bauernsitte sich wieder erfrischen". ${ }^{63}$

In den Entwürfen zum Adelsnest hatte Turgenev seinem Helden Lavreckij im Resümee des Epilogs folgenden Satz in den Mund gelegt: "Ich habe meine Arbeit beendet und ruhe mich jetzt aus, wie ein Pflüger, der mit Mühe und im Schweiße seine Angesichts ein karges Feld urbar gemacht hat" (376, Hervorhebung von mir, P.T.). Auch wenn solche Ubereinstimmungen in Aussage und Formulierung nicht überschätzt werden dürfen, liefern sie doch weitere Indizien für die unmittelbare Verwandtschaft mit Riehls und Bezobrazovs Gedankengut.

\section{Liza}

Lizas Nähe zu Lavreckij hängt mit ihrer Nähe zur "Volkswahrheit" zusammen. Lavreckij ist überzeugt, daß Liza - im Gegensatz zu Varvara - seiner "ehrlichen, strengen Arbeit" und seinem "herrlichen Ziel" nicht im Wege stehen würde (226). Im Streitgespräch mit Panšin spricht er im

62 Vg!. Die bürgerliche Gesellschan, asO., S. 164 f. und 185 f. Siehe auch die oben angeführte Definition Bezobrazovs, der Bauernstand sei “jenes letzte historische Reservoir der Volkssäfte, aus denen sich alle Gesellschaftsklassen erneuern"!

63

Die bürgerliche Gesellschaft, ^aO., S. 63 (Hervorhebung von mir, P.T.). 
Grunde "nur für Liza", die dabei ihrerseits "ganz auf seiten Lavreckijs" steht (233 f.). Liza verachtet gutsherrliche Arroganz und fühlt sich zu den russischen Bauern hingezogen, mit denen sie "wie mit ihresgleichen" spricht. Panšins Herablassung gegenüber Rußland empfindet sie als beleidigend (234).

Turgenev hat Lizas Vorgeschichte in einer eigenen Retrospektive dargestellt (Kap. 35). Wir erfahren, daß Lizas Gouvernante, eine "leichtsinnige kleine Französin" aus Paris, wenig Einfluß auf sie hatte. Dafür war die Erziehung durch die russische Kinderfrau um so nachhaltiger. Die Njanja stammte aus einer "Bauernfamilie", war "schweigsam und fromm", lehrte Liza das Beten und die Liebe zu Christus. Das alles hat Liza "bis ins Innerste ihres Wesens" geprägt (242), und sie hat die einfache Kinderfrau mehr geliebt als ihre prätentiös-unreligiöse Mutter. Mit ihrer Sympathie für die "russischen Menschen" war Liza, wie Turgenev betont, ganz unbewußt eine "Patriotin" (234), und die Religion gehörte zu ihrem selbstverständlichen Lebensinhalt. Auf weltliche Bildung und Fertigkeiten legte sie wenig Wert; Gedanken waren ihr wichtiger als Worte, und mit ihrem "guten und sanften Herzen" ging sie entschlossen "ihren Weg" (211 und 243). Das alles entspricht Riehls Beobachtung, in der sogenannten besseren Gesellschaft herrsche oft "religiöse Gleichgültigkeit" und falsche Bildungspolitur, während "die Religion und der Patriotismus" der einfachen Menschen dem naiven Instinkt und der Sitte entsprängen ${ }^{64}$.

Liza besitzt typologische Ähnlichkeit mit Lavreckijs Mutter Malan'ja. Beide verbindet das Bauernmotiv, die Demut, das "gute Herz" und eine gewisse Parallelität im unglücklichen Lebensschicksal. Umgekehrt haben Lavreckijs Vater und Varvara eine verwandte Typologie. Die Konstellation von Lavreckijs Eltern wiederholt sich schicksalhaft in der Opposition der von Lavreckij geliebten Frauen. In beiden Fällen stehen Einfachheit, Ergebenheit und Konsequenz gegen Adelsprätention, Egoismus und Inkonsequenz.

Liza und Lavreckij sind über die Nähe zum Bauerntum miteinander verbunden. Das verdeutlicht Turgenev auch durch unscheinbare Korrespondenzen. So wird Lavreckij vom Erzähler als "linkisch" (nelovok, 162) beschrieben. Die gleiche Charakterisierung ist auch in Lizas Beschreibung enthalten, indem von ihrer "etwas linkischen Grazie" (neskol'ko nelovkaja gracija, 243) die Rede ist. Die Kennzeichnung

$64 \mathrm{~V}$ l. ebda. S. 56, 64 u.ö. Siehe auch die der Kirche gewidmeten SchluBkapitel in Land und Leute, aaO., S. 309 fr., sowie ebda. 214 f. 
"schwerfällig, linkisch" gehörte zum festen Wortgut von Bauerndarstellungen ${ }^{65}$. Zugleich steckt darin ein Indiz, daB Lavreckij und Liza nicht $\mathrm{zu}$ jenen geschliffenen Adelsvertretern gehören, die Turgenev ironisch als "Petersburger Pariser" (133) bezeichnet. Panšin wird ausdrücklich als "gewandter" Petersburger charakterisiert, der "dejstvitel'no očen' lovok" sei $(134)^{66}$.

\section{Die "Petersburger Pariser"}

Der französisierte, amoralische und absentistische Adel wird im Roman einer scharfen Kritik unterzogen. Turgenev setzt hierfür die Mittel der direkten und indirekten Personencharakteristik ein, wobei er vor allem die Motive und Themen der französischen Sprache, des Kartenspiels, der Musik, des Theatralischen, des "Nestes", der Bürokratisierung und des Patriotismus verwendet. Der Roman offenbart eine Zivilisationskritik, verbunden mit Mißtrauen gegen Großstadtleben, Zentralismus und Rationalismus, wie sie in Riehls Naturgeschichte des Volkes auf Schritt und Tritt begegnet.

$\mathrm{Zu}$ den "Petersburger Parisern" gehören von den handelnden Personen in erster Linie Varvara Pavlovna mit ihrer Tochter Adočka sowie Panšin. Mit einigem Abstand auch Mar'ja Dmitrievna und Gedeonovskij. Von den nichthandelnden Personen ist vor allem Lavreckijs Vater zu nennen. Sie alle sind dem russischen Volk, seiner Sprache und Kultur entfremdet. Varvaras Bekenntnis zu ihrem "russischen Herzen" und Mar'jas Ausspruch "la patrie avant tout" (255 f.) sind hohle Phrasen. Der Bürokrat Panšin sieht Rußlands Krankheit darin, daß "wir nur zur Hälfte Europäer geworden sind" (231). Mit Verwaltungsmaßnahmen der Staatsbeamten könnten alle Schwierigkeiten sofort geregelt werden, zumal die staatliche Administration Vorrang vor dem Volksleben habe (231 f.). Bezeichnenderweise hat er in Petersburg den Auftrag erhalten "de populariser l'idée du cadastre" (215; vgl. 231). Die schwierigsten Probleme, sogar die "Zukunft Rußlands" glaubt er, ähnlich wie Mar'ja Dmitrievna, "mit zwei Worten" lösen zu können $(215,265)$, und "diplomatisches" Taktieren gehört zu seinen Wesenszügen $(262,266)$. Er ist ein typischer Vertreter der von Riehl allent-

65 Vgl. z.B. Die bürgerliche Gesellschan, aaO., S. 61!

66 Das Adjektiv "lovkij/nelovkij” war in den Entwūrfen des Romans als Codeträger noch häufiger vertreten, vgl. Socinenija Bd. 7, S. 308, 329 und 353. 
halben beklagten "bureaukratischen Bevormundung" durch den "erkünstelten Stand" des zentralistisch denkenden Beamtentums, das sich durch "Kanzleieifer" hervortun wolle ${ }^{67}$. Der Epilog zeigt ihn auf der Höhe seiner Petersburger "činovnik"-Karriere (287). Riehl hat das "System der russischen Tschins" kritisiert, weil er in ihm eine Variante des "modernen nivellirenden Polizei- und Beamtenstaates" zu erkennen glaubte $^{68}$. Der russische Adel, so Riehl, verliere infolge seines Hofund Staatsdienstes "zum Schaden des Landes" seine Selbständigkeit, während der russische Bauer durchaus noch korporative Eigenständigkeit besitze ${ }^{69}$. Es dürfte kein Zufall sein, daß Lavreckij - entgegen dem Wunsch Varvaras - nicht in den Staatsdienst eintritt (172).

Die "Petersburger Pariser" bevorzugen die französische Sprache, während sie das Deutsche eher verachten (133). Liza dagegen spricht mit Lemm manchmal deutsch (143). Varvara und Panšin finden über die französische Konversation sofort zur Vertrautheit des "confrère" (262 ff.), und Mar'ja Dmitrievna fühlt sich dabei wohl "wie im besten Pariser Salon" (264). Der Erzähler bezeichnet die inhaltslosen Plaudereien der "Pariser" leitmotivisch als "Geschwätz" (boltovnja), wodurch der Gegensatz zu Lavreckijs Bildungseifer und Lizas "fehlenden Worten" verstärkt wird. Das Spiel der kalkulierten Posen und Phrasen steht gegen die stumme Kommunikation des echten Gefühls. Nachdem Liza Panšins Antrag abgelehnt hat, verabschiedet sich dieser taktlos mit einem französischen Satz (252). Varvara und Panšin haben "nur französische Bücher" gelesen (264). Marfa Timofeevna dagegen bringt den französischen "dialecht", wie sie despektierlich sagt, mit Verlogenheit in Verbindung (128).

Das französische Element signalisiert bei all dem nicht nur die Entfremdung von Rußland, sondern zugleich verderblichen Moralverlust. Indem Varvara mit allen Mitteln nach Frankreich strebt, vertauscht sie das 'gesunde' Dorf mit der 'kranken' Großstadt. Von Anfang an war Lavriki für sie nicht mehr als ein "Steppennest" (171), und alle ihre Gedanken kreisten nur "um Paris" (264). Die Stationen Lavriki Petersburg - Paris bezeichnen zugleich mit der Entfernung von Rußland die Annäherung an den Ehebruch.

Hier offenbart sich einmal mehr Turgenevs Vorliebe für den Gegensatz von geschlossenen und offenen Räumen. Die weite Szenerie der

\footnotetext{
$67 \mathrm{Vgl}$. Die bürgerliche Gesellschaft, S. $76 \mathrm{ff}$., $96 \mathrm{ff}$. und $284 \mathrm{ff}$.

$68 \mathrm{Vgl}$. ebda. S. 7 ff., das Tschin-Zitat S. 9.

69

Ebda. S. 170 f.
} 
russischen Naturbilder Feld, Wald, Steppe und Garten benennt in der Regel gesunde, organisch gewachsene Räume, die den moralisch guten Helden zugeordnet werden. Die moralisch verdorbenen oder zumindest indifferenten Protagonisten dagegen werden häufig in der mondänen Stadt, im Hotel, Ballsaal oder Salon gezeigt. Die Enge und Künstlichkeit dieser 'anorganischen' Topographien spiegeln den Verlust von Natürlichkeit, Heimat und Gewissen. Ihre Bewohner unternehmen Spaziergänge, Ausfahrten oder Jagdausflüge nur aus taktischen Gründen, während Naturnähe ein konstitutives Kennzeichen der positiven Helden ist. In die Raumopposition wird von Turgenev auch das Bild des Adelsnestes einbezogen. Während im Text gewöhnlich von "gnezdo", "rodimoe gnezdo" oder "rodovoe gnezdo" die Rede ist $(150,172,289)^{70}$, hat sich Varvara in Paris ein "gnezdyško" eingerichtet (173). Mit gleicher Deminutivbildung bezeichnet ihr französischer Galan den gemeinsamen Treffpunkt als "našu kvartirku" (175). Varvara ist zu einer "reinrassigen Pariserin" geworden (173), die das russische Adelsnest mit einer Pariser Absteige vertauscht ${ }^{71}$ und ihre Heimat zugunsten einer fragwürdigen Demimonde verrät.

Ein französisch geschriebenes Billet doux des Liebhabers bringt Lavreckij auf die Spur des Treuebruchs, und Varvara kommentiert ihre Verfehlung in verräterischer Weise mit einem französischen Brief (174 f., 177). Bei ihrer unverhofften Rückkehr nach Rußland tritt sie Lavreckij geschmacklos und verletzend mit einem geheuchelten Schuldbekenntnis in französischer Sprache entgegen (245). Als sie den Zweck ihrer Reise - Lavreckij Geld zu entlocken - erreicht hat, kehrt sie alsbald nach Frankreich zurück. Dabei wiederholen sich die Stationen Lavriki Petersburg - Paris. Sie sind Stufen des Absentismus und Sittenverfalls. In Lavriki und Petersburg wird Panšin Varvaras "versklavter" Geliebter, in Paris schenkt sie ihre Gunst einem "ukrainischen Stier". Die französischen Besucher ihres Salons nennen ihn "le gros taureau de l'Ukraine" (288).

Die chronique scandaleuse Varvara Pavlovnas kann als literarische Gestaltung dessen angesehen werden, was Riehl als "Sittenverderbnis" des Hofadels beschreibt, der in seiner Frivolität oft nur

$70 \mathrm{Vgl}$. auch die vielen Belegstellen zu "gnezdo" in Turgenevs Briefen (Pis'ma Bd. 1, 1961, S. 41/Anm. 25)! Dazu auch Socinenija Bd. 7, 1964, S. 458.

71 Man vergleiche auch den Kontrast der beiden Kutschfahrten, die einmal Liza und Lavreckij in reiner Harmonie (212), zum anderen Varvaras frivoles Spiel mit Gedeonovskij zeigen (267). 
eine "Spiel-, Tanz- und Zechgesellschaft" darstelle. Das gelte vor allem für den französischen Adel, doch auch der deutsche Hofadel sei "verwälscht und kosmopolitisch" gewesen und habe sich in seiner Gallophilie die französische Sprache zu eigen gemacht. Als besonders gefährlich erachtet Riehl den "frivol zerrütteten Familiengeist", der zur "Familienlosigkeit" und damit zum Untergang des Adels führe. Wenn der Adel nicht sein "Familiengut" zusammenhalte und sich nicht zugleich der "Geistesbildung" widme, werde er seinen "socialen Beruf" verfehlen. Voraussetzung für die Gesundung des Adelsstandes sei die Abkehr vom Absentismus und "feste Seßhaftigkeit", die ein "unschätzbares Gut" sei. Das betreffe vor allem den Landadel, damit die "städtische Verderbniß" nicht ins Dorf getragen werde ${ }^{72}$. Im übrigen rechnete Riehl Petersburg zu den "künstlichen Städten", die mit dem "Zwangsmittel des Despotismus" errichtet worden seien ${ }^{73}$. Auch Badeund "Touristenstädte" lehnte er als Ausdruck einer "überfeinerten Civilisation" $a b^{74}$.

Die Frivolität der "Spiel-, Tanz- und Zechgesellschaft" findet auch sonst im Adelsnest Ausdruck. Panšin, Gedeonovskij, Mar'ja Dmitrievna und Varvara werden häufig beim Kartenspiel gezeigt, während Liza, Lavreckij und der Deutsche Lemm niemals oder nur ganz selten spielen. Turgenev liebt es, die Gruppe der Kartenspieler im gleichen Raum mit den Nichtspielern zu konfrontieren, die sich statt dessen mit ernster Musik oder im Schweigen verständigen (vgl. 225 und 233). Bevorzugt werden die französischen Spiele Piquet und Preference. Varvara wird ausdrücklich als "große Preference-Liebhaberin" charakterisiert (260). Zugleich hat sie eine Vorliebe für das Tanzen. In Petersburg arrangiert sie "Tanzabende" (172) und in Paris glänzt sie als Walzerkönigin (174). Von Panšin erfahren wir, daß er "ausgezeichnet tanzte" und zu Zechgelagen ging $(134)^{75}$. Lavreckij dagegen hält sich von all dem fern.

Ein weiteres Mittel, die Personenkonstellation zu verdeutlichen, ist die Musik. Lemm, Liza und Lavreckij sind Anhänger der ernsten Musik, die mit echter Kunst und idealistischer Erhebung gleichgesetzt wird. Ihre Lieblingskomponisten sind deutsche Klassiker wie Bach, Händel

$72 \mathrm{Zu}$ den Zitaten vgl. Die bürgerliche Gesellschaft, aaO., S. 76, 142, 163 f., 179, $189 \mathrm{f}$.

73 Land und Leute, aaO., S. 86.

74 Ebda. S. 89. - Zu "Civilisation" vgl. Febvre 1988.

$75 \mathrm{Vgl}$. dazu Riehls süffisante Bemerkung über die adelige Unsitte des "nobiliter bibere", Die bürgerliche Gesellschaft, aaO., S. 165 f. 
oder Beethoven. Lemm komponiert Kantaten und ist zu schöpferischem Schaffen fähig (238). Liza, obwohl nicht besonders begabt, spielt recht gut Beethoven, was ihrer Mutter dennoch auf die Nerven geht (193). Lavreckij liebt, trotz fehlender musikalischer Ausbildung, die "klassische Musik" über alles $(162,193)$. Noch im Epilog läßt ihn der Erzähler nach Lemms Kompositionen fragen (291), aus denen einst "Inspiration, Glück, Schönheit" erklangen (238). Panšin dagegen zieht die "leichte Musik" vor (137), weshalb ihn Lemm einen "Dilettanten" nennt (143, 197). Varvara liebt, wie Panšin, Romanzen, vor allem aber italienische und französische Arien (174, 259 f., 263 u.ö.). Sie spielt StrauBwalzer, Etuden von H.Herz und Mazurkas von Chopin (169 f., 258 f.). Ihre und Panšins Darbietungen, manchmal im Duett vereint, sind Ausdruck von Pose und bloß technischem Können. Für beide ist die Musik ein Mittel des taktischen Spiels und oberflächlicher Gefühle. Das gilt auch für Panšins 'Malkunst': Er beherrscht nur eine einzige Bleistiftzeichnung (142 f.), die er gleichwohl immer wieder geschickt einzusetzen versteht. Mar'ja Dmitrievna ihrerseits entlarvt sich, indem sie den Salonauftritten ihrer "Petersburger Pariser" überschwenglichen Beifall zollt.

Varvaras Vorliebe für italienische Opern und französische Arien findet eine Fortsetzung in ihrem Hang zu theatralischen Szenen. Turgenev verdeutlicht das mit dem Motiv des Melodramatischen, welches in der Zeichensprache des Romans soviel wie falsche Rührung und Inszenierung scheinheiliger Gefühle bedeutet. Bezeichnenderweise erfolgt die erste Begegnung Lavreckijs mit seiner künftigen Frau in der Welt des Theaters. In einer "Loge der Beletage" erblickt er die junge Korob'ina und gerät sofort in ihren Bann (166 f.). Hierbei ist signifikant, daß Lavreckijs Freund Michalevič die Korob'ina als "geniales" und "herzensgutes" Geschöpf bezeichnet (167). Michalevič verkörpert im Roman den "Poeten" und "Enthusiasten". Enthusiasmus aber ist in Turgenevs Denksystem immer ein Indiz für idealistische Blindheit, die zwar edlen Motiven entspringt, doch zumeist zu verderblicher (Selbst)Täuschung führt.

In Paris wird Varvara beim Besuch eines "ultraromantischen Melodramas" zu Tränen gerührt (174). Bei ihrer Rückkehr nach Rußland inszeniert sie mit ihrem Töchterchen einen theaterhaften Auftritt, der Lavreckij an das Geschehen in einem "Melodrama" erinnert (246). Gemäß der Personenkonstellation ist auch Mar'ja Dmitrievna für melodramatische Szenerien empfänglich. In Kapitel 43 möchte sie, in Übereinstimmung mit Varvara, eine pathetische Versöhnungsszene arrangieren, doch Lavreckij läßt sich nicht überrumpeln und verwahrt 
sich gegen ihre Vorliebe für "gefühlvolle Szenen". Der Erzähler bestätigt ihr obendrein eine Affinität zur "Theatralik" (278). Panšin wiederum verleiht seiner Stimme ein "melodramatisches Zittern", als er Varvara bei ihrer ersten Begegnung seine Romanze vorsingt (262). Zur theatralischen Scheinwelt gehören auch Varvaras geheuchelte Kniefälle und die Kosefloskeln "Engel/Engelchen", die die "Petersburger Pariser" untereinander austauschen (130, 246, 254, 277 u.ö.). Varvaras Liebhaber beginnt sein Billet doux mit den Worten "Liebster Engel Betsi!" (174). Der Widerspruch von Worten und Taten, den Lavreckij zu überwinden sucht, ist für Panšin und Varvara konstitutiv. Das melodramatische Moment avisiert neben Kalkül und Verführung die Welt des müßiggängerischen Rituals. Auch Riehl hatte das "leere Ceremoniell" im Leben mancher Aristokraten kritisiert ${ }^{76}$. Auf seiten Lizas und Lavreckijs dagegen stehen Aufrichtigkeit, tiefe Empfindung, Arbeitsbereitschaft und wahre Tragik.

Die wachsende Dekadenz wird schließlich auch an Varvaras Kindern demonstriert. Ein erster Sohn stirbt noch in Petersburg kurz nach der Geburt (172). Bei der Entdeckung des Ehebruchs in Paris ist Varvara abermals schwanger (176). Nach der Trennung von Lavreckij kommt eine Tochter zur Welt - das "Engelchen Adočka". Der Erzähler spricht zwar nirgends explizit aus, daß Adočka von Varvaras Liebhaber stammt, doch führt die Autorstrategie den Leser eben zu dieser Vermutung. Beim ersten Wiedersehen mit Lavreckij spricht Varvara zunächst von "meiner Tochter" und "meiner Adočka" (245), um kurz darauf Lavreckij korrigierend als "père" und "papa" zu apostrophieren. Schon allein die Wahl des Französischen ist suspekt, und Lavreckij widert die Szene als melodramatisch an (246). Später versucht Mar'ja Dmitrievna mit verdächtigem Nachdruck Lavreckij davon zu überzeugen, wie ähnlich ihm Adočka sei... (277). Das fruchtet natürlich nichts, da Lavreckij über die Vaterschaft längst eine eigene Ansicht hat. In einem Gespräch mit Liza äußert er einmal: "Die Zukunft meiner Tochter, wie Ihr sie...wie Ihr sagt, ist gesichert" (219). Der Nebensatz enthält eine unverkennbare Richtigstellung.

Im Epilog wird Adočka als "mademoiselle Ada" beschrieben, die in Paris zu einem blassen und schwachbrüstigen Mädchen herangewachsen ist, dessen "Nerven schon ruiniert waren" (288). Riehl hatte sich dezidiert über die "Bedeutung der Nervenkraft" für den Kulturstand eines Volkes geäußert. Er sprach dabei vom "ruinirten Nervensystem

76 Ebda. S. 168 f. 
unserer städtischen Bevölkerung", während der grobknochige Bauer noch über "gesunde Nerven" und "zähe Ausdauer" verfüge ${ }^{77}$. Wir erinnern uns, daß im Roman mehrfach auf Lavreckijs bäuerliche Konstitution und seine "gesunde Natur" hingewiesen wird (129, 178 u.ö.), die das schmachvolle Geschehen in Paris überdauern werde. Mit Abscheu betrachtet Lavreckij das "abgelebte" und doch noch "pikante Pariser Gesicht" von Adočkas Kindermädchen Justine (270). Varvara dagegen besucht in Paris fleißig Theateraufführungen, in denen "schwindsüchtige und sentimentale Kameliendamen" auftreten (288).

Der Kontrast von "Petersburger Parisern" und "potenziertem Bauerntum" wird durch zahlreiche weitere Facetten verstärkt. Die Opposition setzt sich zum Beispiel in der Gegenbildlichkeit von Komfort vs. Schlichtheit, Blässe vs. gesunde Gesichtsfarbe, Hektik vs. Stille fort. Das Grundmuster des Kontrastes strukturiert die Personenkonstellation und prägt das 'Weltmodell' im Adelsnest. Zugleich basiert die Ideologie auf einer Parallelvorstellung, die den 'gesunden' Adel mit 'gesundem' Bauerntum verknüpft. In Turgenevs ambivalentem Adelsbild liegt die Voraussetzung für das Nebeneinander von Kontrast und Parallele.

\section{Wider die "Weisheit des XVIII. Jahrhunderts"}

Turgenev legt großen Wert darauf, den Leser über die Grundsätze $\mathrm{zu}$ orientieren, nach denen Lavreckij und seine Vorfahren erzogen worden sind. In diesen Erziehungssystemen spielen Rousseau und die französischen Aufklärer eine entscheidende Rolle. So hat Lavreckijs Vater Ivan Petrovič einen französischen Hauslehrer, der als "ehemaliger Abbé", als "Enzyklopädist" und "Schüler Jean-Jacques Rousseaus" beschrieben wird (150 f.). Dieser erschleicht sich das Vertrauen einer ältlichen Tante Ivans, bringt ihr Geld (das für Ivan Petrovič bestimmt war) an sich und "verschwindet nach Paris". Zuvor hat er allerdings den jungen Ivan mit den Lehren der Enzyklopädisten bekannt gemacht, von denen der Erzähler neben "vielen anderen" Diderot, Voltaire, Helvétius, Raynal und auch Rousseau namentlich anführt. Die "Weisheit des XVIII. Jahrhunderts" (premudrost' XVIII veka) sitzt Ivan seitdem im Kopf, allerdings "allein im Kopf", ohne zugleich in "Blut" und "Seele" übergegangen zu sein (151). So heiratet er zwar die Leibeigene Malan'ja, läßt sie aber trotz ihrer Schwangerschaft bald darauf im Stich, gibt das

77 Siehe ebda. S. $60 \mathrm{f}$. 
ihm "verhaßte Dorfleben" auf, geht nach Petersburg, London und Paris, spielt Karten und hält sich eine Geliebte...(154 f.). Diese zweifelhafte Variante 'aufgeklärten Freidenkertums' hat Turgenev auch in anderen literarischen Figuren gestaltet, so z.B. in Varvara Pavlovna oder in Ivan Matveič Koltovskoj in der Erzählung Nesčastnaja aus dem Jahre 1869.

Als Ivan Petrovič um 1820 nach Rußland zurückkehrt, um sich der Erziehung seines Sohnes und der Verwaltung seines Gutes zu widmen, ist er ein angloman-gallophiler Theoretiker, bar jeder moralischphilosophischen Sicherheit und praktischen Lebenserfahrung. Obwohl er darauf fixiert ist, in Erziehung und Verwaltung ein "neues System" zu verwirklichen - "System" ist überhaupt sein Lieblingswort -, bleibt alles beim alten "Chaos" (160). Sein Verhältnis zu den Bauern wird nach wie vor von den Grundsätzen der "barščina" bestimunt. Ivan versucht sogar, seinem Sohn Verachtung gegenüber der Musik und den Frauen beizubringen, während Naturwissenschaften, handwerkliche Fähigkeiten, Heraldik und Körperertüchtigung im Mittelpunkt des "Systems" stehen (162 f.). Über jeden Tag muß dazu in einem Tagebuch Rechenschaft abgelegt werden. Mit all dem soll der junge Lavreckij zu einem Menschen - "un homme" - und zu einem "Sohn der Natur" erzogen werden (162 f.).

Mit fortschreitendem Alter wandelt sich Ivan Petrovič allerdings immer mehr vom europäisch gesinnten "Freidenker" zu einem russischen Egoisten, der am Ende die Kirche und das Dampfhad besucht. Lavreckij bemerkt an seinem Vater den Widerspruch zwischen "liberalen Theorien" und "kleinlichem Despotismus" (164). Nach dem Tod des Vaters konstatiert der Erzähler, daß die "wunderliche Erzichung" (kapriznoe vospitanie, 165) Lavreckij zu einem "Sonderling" gemacht habe. In der Erziehung nach dem "System" eines halben Rousseauismus und oberflächlicher Aufklärungsmaximen liegt eine der Ursachen für Lavreckijs unglückliches Schicksal. Die "hauptstädtische Bildung und Philosophie" des Vaters (154), seine "hauptstädtischen Gewohnheiten" (151) konnten nur zu falschen Vorstellungen und zur Entfremdung vom russischen "Boden" und seinen Landgütern führen. Daher ist Lavreckij gezwungen, zum Selbstdenken und zur Selbsterziehung zu finden, um sich aus der "künstlichen" Enge seiner bisherigen Erziehung zu befreien (vgl. 165, 172 u.ö.). Nur so wird er vermeiden, daß die, wie Riehl sagt, "aller Naturkraft bare Blüthe der städtischen Civilisation" ihn untergehen läßt.

Wenn Lavreckijs Vater durch den Begriff "System" negativ charakterisiert wird (159 f., 162 f.), entspricht das Turgenevs eigener 
Ablehnung eines streng klassifizierenden Systemdenkens. Im Januar 1857 schrieb er dazu in einem Brief an L.N.Tolstoj: "Auf Systeme halten nur jene große Stücke, denen die Wahrheit als Ganzes unzugänglich ist... Ein System ist gleichsam nur der Schwanz der Wahrheit"78. Diese 'Systemkritik' zielte vor allem auf die Aufklärung, sofern sie als bloße Verstandesaufklärung propagiert wurde. Abstraktions- und Rationalismuskult waren Turgenev immer fremd, ebenso Pragmatismus, blinder Fortschrittsglaube und Verabsolutierung der Naturwissenschaft. Wenn die Enzyklopädisten meinten, mittels der Ratio das "wahre System der Welt" (d'Alembert) und das "System der Natur" (Holbach) erkannt zu haben ${ }^{79}$, begegnete Turgenev diesem Aufklärungsoptimismus mit Zweifel. Zu seinem Bildungsbegriff gehörten untrennbar die schönen Künste, das Emotionale, das Numinose, die Unergründbarkeit der Natur und eine in vielem idealistisch orientierte Philosophie. Skeptisch betrachtete er auch die Theorie vom Gesellschaftsvertrag und die Kulturkritik (nicht hingegen die Zivilisationskritik) des Rousseauismus. Er hat daher wiederholt nicht nur die eigentlichen Enzyklopädisten, sondern auch Rousseau als Mittel der indirekten, negativen Personencharakteristik eingesetzt. Gegenüber Rousseau empfand er nach eigenem Bekunden Abneigung ${ }^{80}$; er warf ihm überdies "phraséologie", Unaufrichtigkeit und Fanatismus vor ${ }^{81}$. In Umkehrung von Rousseaus Lehre hängt Turgenev eher, überspitzt formuliert, einem Bildungsoptimismus und einem Tugendpessimismus an, wobei er für beide die Dominanz des Rationalismus ablehnt. In der erwähnten Erzählung Nesčastnaja dienen Raynal, Helvétius, Voltaire und überhaupt "die Enzyklopädisten" dazu, die verlogenen Lebensund Erziehungsprinzipien des "vollkommenen Franzosen" Koltovskoj zu demaskieren ${ }^{82}$.

78 Pis'ma Bd. 3, 1961, S. 75.

79 Vgl. Chr. Helferich, Geschichte der Philosophie, Stuttgart 1985, S. 152166. Siehe ansonsten im Historischen Wörterbuch der Philosophie, hrsg. v. J.Ritter, die Artikel "Aufklärung", "Enzyklopädie" und "Freidenker". Im Handbuch philosophischer Grundbegriffe, hrsg. v. H.Krings u.a., die Artikel "Aufklärung" und "System".

80 Vgl. Pis'ma Bd. 2, S. 197 ("Russo, k kotoromu serdce moe davno ne ležit").

$81 V_{g l}$. ebda. Bd. 1, 1961 , S. 396; Bd. 3, S. 117 und 138; Bd. 6, S. 27; siehe auch Brang, aaO., S. 21.

$82 \mathrm{Vgl}$. Socinenija Bd. 10, 1965, S. 106 ff. die Lebensgeschichte der "Unglücklichen"; siehe dazu auch Brang, aaO., S. 159. 
In der Polemik gegen die "Weisheit des XVIII. Jahrhunderts" trifft sich Turgenev abermals mit Riehl. Für diesen war die "Zopfzeit" ein Schreckgespenst, kaum mehr als ein "Zwischenakt krankhafter Reaktion"83. Hinter der Fassade rationaler Aufklärung verberge sich konstruierende Systemsucht, Freidenkertum, Kosmopolitismus, soziale Nivellierung, Moralverlust sowie Entfremdung von Geschichte, Volk und Natur. Das 'philosophische Jahrhundert' wird von Riehl folgendermaßen beschrieben: "Es geht durch diese Zeit ein mächtiger Zug zum Aufbau des Allgemeinen, Einheitlichen, zur Centralisirung und Uniformirung in der Politik, zur theoretischen Construction in der Wissenschaft. Es war weit mehr eine Zeit der Systeme als der empirischen Analyse" ${ }^{\text {" }}$. Der Rationalismus des XVIII. Jahrhunderts sei eine "zersetzende Philosophie" ${ }^{85}$. Großstadtzivilisation und "Lustschlösser" hätten das natürliche Landleben und die soziale Harmonie zerstört: "Die Zopfzeit hatte kein Auge für den Wald, sie hatte entsprechend auch kein Verständniß für das Naturleben im Volksthum, keine Ahnung von den natürlichen socialen Besonderungen"86. An die Stelle eines gesunden Bauerntums und Landadels sei der "ausstudirte Städter" getreten, dessen moderne Bildung vom Volksleben durch eine "tiefe Kluft" getrennt sei ${ }^{87}$. Wahre Bildung bemesse sich aber nicht danach, "wie viel Procent von Artikeln des Conversationslexicons" man im Kopfe habe, denn der "Geist des Encyklopädismus" sei "kein guter Geist gewesen"88.

Riehls Kritik richtet sich nicht nur gegen "Encyklopädismus" und "rationalistische Aufklärung" (einschließlich Hegels) im allgemeinen, sondern zugleich in aller Schärfe gegen Rousseau. Er wirft den Franzosen vor, sich in "Constructionen aus der Luft gegriffener Gesellschaftsbildungen" zu verrennen, und verspottet die Theorie vom Gesellschaftsvertrag: "In Frankreich tritt der epochemachende Meister der Construction der Gesellschaft auf: Rousseau. Nicht die Untersuchung des Volksorganismus als einer historischen Thatsache, sondern das Phantasiebild eines 'Gesellschaftsvertrages' stellt er an die Spitze seiner neuen Gesellschaftswissenschaft...die Franzosen

83 Land und Leute, aaO., S. 6 u.ö.; vgl. auch Die bürgerliche Gesellschant, aaO.,

S. 191, wo die Zopfzeit als die "traurigste Zeit" bezeichnet wird.

84 Land und Leute, aaO., S. 13 (Hervorhebung von mir, P.T.).

85 Ebda. S. 332.

86 Ebda. S. 49.

87 Ebda. S. 47, 349 u.ö.

88 Ebda. S. 94 und 209. 
haben bis jetzt stets nur eine verneinende, nivellirende, nicht aber eine positive, conservative sociale Politik gewinnen können"89. Rousseau sei der "Ahnherr der socialen Doctrinäre", der wie Voltaire rationalistische Theorien über die natürliche Ungleichheit von Menschen und Gesellschaftsgruppen stelle ${ }^{90}$. Für die Reform der Gesellschaft seien jedoch nicht Systementwürfe und allgemeine Kategorien erforderlich, sondern das "Studium des Volkes", moralische und historische Besinnung sowie eine Politik, welche Adel und Bauerntum als "Mächte des socialen Beharrens" zur Grundlage einer neuen "Social-Politik" mache ${ }^{91}$. Das entsprach im wesentlichen den Grundsätzen der Slavophilen und Turgenevs slavophiler Position im Adelsnest. Beide wollten wie Riehl von sozialkonservativer Basis her die Zukunft sichern.

\section{Schluß}

Turgenev wollte mit seinen Romanen "the body and pressure of time" erfassen ${ }^{92}$, und man hat zu Recht gesagt, er stelle seine Gegenwart als "dokumentierte Geschichte" dar. Dem entspricht, daß sich bei ihm eine weitgehende Identität von Autor und Erzähler findet ${ }^{93}$. Der "avtorrasskazčik" bzw. "avtor-chudožnik" lenkt gemäß seiner Weltsicht die Leserrezeption, wobei der Autorstrategie auch Orientierungen an der europäischen Geisteswelt zugrunde liegen ${ }^{94}$. Granjard sieht richtig, wenn er für das Adelsnest von einer Personalunion "Lavretski - Tourguénev" spricht ${ }^{95}$. Turgenevs briefliche und publizistische Äußerungen können mit großer Verläßlichkeit als Kommentare zu seinem literarischen Schaffen herangezogen werden. Wenn Turgenev mitteilt, er habe Riehl "mit GenuB" gelesen, und wenn er ihn 1867 im Roman Rauch unter die zeittypischen Autoren einreiht, müssen wir diese Zeugnisse ernst nehmen.

89 Ebda. S. 9.

90 Ebda. S. 10.

91 Die bürgerliche Gesellschaft, aaO., S. 30-38.

$92 \mathrm{Vgl}$. sein Vorwort zu den Romanen von 1879, in: Soxinenija Bd. 12, 1966, S. 303. Quelle ist Shakespeare's Hamlet, III. Akt, 2. Szene.

$93 \mathrm{Vgl}$. dazu zuletzt überzeugend Cudakov 1987; ebda. S. 262 (im AnschluB an L.Dolotova) die Formel von der "dokumentierten Geschichte".

94 Ebda. S. $259 \mathrm{fr}$. Zu erinnern ist natürlich auch daran, daß sich Turgenev als "unverbesserlichen Westler" und Deutschland als sein "zweites Vaterland" bezeichnet hat, vgl. Socinenija Bd. 14, 1967, S. 100 und Bd. 15, 1968, S. 101.

95 Granjard 1966, S. 248. Siehe auch Socinenija Bd. 7, S. 481 f. 
Nicht zufällig konstatiert Batjuto für das philosophische Denken in Turgenevs Romanen einen "začastuju reminiscentnyj, počti 'citatnyj' charakter" ${ }^{96}$.

Es wäre allerdings verfehlt, die Übereinstimmungen zwischen dem Adelsnest und Riehl allein im Sinne einer monokausal-genetischen Abhängigkeit erklären zu wollen. Turgenev hat die These von der russischen Ständeharmonie zwischen Adel und Bauern in wesentlichen Punkten schon vor Riehls Theorie der "beharrenden Mächte" entwickelt. Auch seine Aversion gegen einseitigen Rationalismus und Rousseauismus ist bereits früh bemerkbar, ebenso seine Kritik am Absentismus und Moralverlust des Adels. Schon Ležnev in Rudin kann als ein Held verstanden werden, der die Aufgabe des Landadels darin sieht, das "Land zu pflügen"97. Im übrigen wurde der Vorwurf des Kosmopolitismus häufig mit Paris verbunden und war ein fester Topos der Literatur. So erschien 1858 in Herzens Kolokol ein Bühnenstück mit dem Titel Russkie v Pariže $v 1858 \mathrm{~g}$., dessen Autor wahrscheinlich Ivan Aksakov war ${ }^{98}$. Lavreckij dagegen ist, wie Apollon Grigor'ev formulierte, ein "čelovek počvy" 99 .

Trotz Turgenevs konzeptioneller Selbständigkeit können Riehls Schriften sowie ihre Vermittlung durch Katkov, Bezobrazov und die Slavophilen für die Botschaft des Adelsnestes zusätzliches Verständnis schaffen. Wir haben es mit dem diffizilen Phänomen einer sowohl typologischen wie genetischen Verwandtschaft zu tun ${ }^{100}$. Antizipation und Rezeption überlagern sich und verschmelzen in der poetischen Struktur des Textes zu einer originalen Einheit. Turgenev, der nach eigenem Bekenntnis für seine Protagonisten und ihre Handlung immer eines "gegebenen Bodens" bedurfte ${ }^{101}$, fand in den deutschen und russischen Diskussionen um die Rolle des Adels nach 1855 vielfach eine Bestätigung und Vertiefung dessen, was er bereits selbst durchdacht hatte. Gerade die Publikationen im Russkij Vestnik und in der Russkaja Beseda 1857/58 dürften ihm wesentliche Impulse für die thematische Anlage des Adelsnestes ge-

96 Batjuto 1972, S. 162.

97 Vgl. dazu auch Nikitina 1987, S. 154.

$98 \mathrm{Vgl}$. dazu ausführlich Dudzinskaja 1986, S. 76 ff.; 24 Gogol's Kritik am "französischen Element ${ }^{n}$ in den Toten Seelen vgl. zuletzt Erofeev 1988.

99 Grigor'ev 1967, S. 316 u.ö. Hierbei sei daran erinnert, daB die späteren Slavophilen relativ früh einen gewissen 'Kult der Steppe' entwickelt hatten, vgl. z.B. Chomjakovs Gedicht Stepi aus dem Jahre 1828.

100 Zum komparatistischen Problem von Kontaktbeziehungen und typologischen Analogien vgl. die grundsätzlichen Ausführungen bei Durišin 1972.

101 Socinenija Bd. 14, 1967, S. 97. 
geben haben. Die Verlegung der Handlungszeit des Romans in das Jahr 1842 darf darüber nicht hinwegtäuschen. Riehl war offenbar nicht nur für Katkov und Bezobrazov, sondern auch für Turgenev ein willkommener Gewährsmann für die Richtigkeit der eigenen Überzeugungen. Der "westliche Slavophile" Riehl, wie ihn Samarin und Ivan Aksakov nannten ${ }^{102}$, lieferte konzentrierter und übersichtlicher als andere Publizisten jene Argumente, die die russischen Verfechter einer konservativen Ständeharmonie und notwendigen Funktion des Adels im Reformprozeß nach 1855 verwenden konnten.

Wenn Turgenev in Dvorjanskoe gnezdo den Adligen Lavreckij als "potenzierten Bauern" darstellt und das bäuerische Volkstum als Fundament für Lebenskraft und naturreligiöse Moral preist, wenn er zugleich den absentistischen Adel als 'verwelscht' und amoralisch ansieht, wenn er zudem Bürokratismus und Zentralismus verwirft, verbunden mit der Verurteilung eines rein rationalistischen "Enzyklopädismus", dann stimmte er hierin mit Riehl und den Slavophilen fast nahtlos überein. Lavreckijs programmatische Ansicht von der unverbrauchten Jugendkraft und "Volkswahrheit" Rußlands (232), zu der auch der moralisch intakte Adel gehört, hat bei Riehl und den Slavophilen eine genaue Entsprechung. Und bezeichnenderweise hat Dostoevskij das Adelsnest gerade wegen seiner "Volkswahrheit" und "Volksideale" besonders geschätzt ${ }^{103}$.

Auf der anderen Seite offenbart sich die grundsätzliche Abkehr von Černyševskijs und Dobroljubovs Adelsverdikt, weshalb Turgenev nach der Publikation des Adelsnestes den Sovremennik verläßt und zusammen mit Tolstoj Autor des Russkij Vestnik wird. In der unvollendeten Abhandlung über den Adel von 1858 und im Adelsnest nimmt er gegen Černyševskij Stellung, indem er zur eigenen Überzeugung Riehls These heranzieht, der Adel sei nicht nur reformfähig, sondern sogar zur Führerschaft in der gesellschaftlichen Neugestaltung bestimmt. Er setzt damit, wenn auch mit anderen Akzenten, eine Polemik fort, die er schon in Rudin gegen Černyševskij gerichtet hatte ${ }^{104}$. Černyševskij seinerseits

102 Vgl. Thiergen 1978, S. 197 und 212.

$103 \mathrm{Vg}$. Dnevnik pisatelja za 1876 god, in: F.M.Dostoevskij, Polnoe sobranie socinenij $v$ tridcati tomach, Bd. 22, Leningrad 1981, S. 44 (im Kapitel O jubvi k narodu. Neobchodimyj kontrakt s narodom); siehe auch ebda. S. 189 f. die Varianten, die noch ausführlicher auf das Adelonest eingehen (dazu Budanova 1987, S. 130 f.). Auch Liza ist von Dostoevskij, im Vergleich zu Puškins Tat'jana, mit höchstem Lob bedacht worden, vgl. Bd. 26, 1984, S. 140.

$104 \mathrm{Vgl}$. dazu Thiergen 1980, S. $37 \mathrm{ff}$. 
polemisierte nicht nur, wie bekannt, gegen Turgenev (vor allem in seiner Kritik der Erzählung Asja von 1858), sondern auch gegen Bezobrazovs Aufsätze im Russkij Vestnik ${ }^{105}$.

Im übrigen bestätigt ein Blick auf die Textgeschichte des Romans, daß Turgenev das Konzept des "potenzierten Bauern" für die Endfassung des Buches verstärkt hat. Lavreckijs Charakteristik als "Bauer" wird durch mehrere Textergänzungen intensiviert, während umgekehrt die Kritik an seinem anfänglichen gesellschaftlichen Versagen gemildert wird $^{106}$. Auch Liza erhält durch die Hinzufügung ihrer Vorgeschichte (Kap. 35) eine stärkere Verknüpfung mit dem russischen Volkselement. Zudem entfernt Turgenev in der ersten Einzelausgabe des Romans (ebenfalls 1859) das ursprünglich verwendete Motto "Na čto duša roždena, togo Bog i dal"107. Die Redensart, die als Ausdruck einer schicksalhaften Determination angesehen werden kann, hätte dem Handlungsentschluß des "Pflügers" Lavreckij widersprochen. Bemerkenswert ist weiterhin, daß wohl auch der Titel Dvorjanskoe gnezdo erst im Laufe des Jahres 1858 gewählt worden ist, obwohl die Formel bei Turgenev auch schon früher begegnet ${ }^{108}$. Schließlich hat Turgenev auch die anfängliche Absicht, in der Gestalt Lizas ein "religiöses Geschöpf" zur "Hauptfigur" des Romans zu machen ${ }^{109}$, verworfen. Statt dessen dominiert am Ende der "potenzierte Bauer", auch wenn die religiöse Thematik mit Liza erhalten bleibt. Es ist naheliegend, daß diese thematischen Verschiebungen und die textologischen Änderungen auf Überlegungen zurückgehen, die mit den Lektüreerfahrungen und Diskussionen des Jahres 1858 zusammenhängen. Erst wenn zum textimmanenten ein zugleich kontextorientiertes Lesen tritt, wird man für Turgenevs Romane ein ganzheitliches Verständnis gewinnen.

$$
\prec \diamond \succ
$$

$105 V_{g l}$. u.a. Revoljucionnaja situacija $v$ Rossii $v$ seredine $X I X$ veka. Kollek. tivnaja monografija, pod red. M.V.Nečkinoj, Moskva 1978, S. 71.

$106 \mathrm{Vgl}$. dazu Socinenija Bd. 7, S. 466 f., 477 und 479.

107 Vgl. ebda. S. 305, 451 und 479.

108

$109 \mathrm{Vgl}$. seinen Brief vom Dezember 1857 an die Gräfin Lambert, Pis'ma Bd. 3, 1961, S. 179 (Hervorhebung von mir, P.T.). 
Trotz der poetischen Suggestivkraft des Adelsnestes bleibt festzuhalten, daB der idealisierende Entwurf einer Ständeharmonie und eines potenzierten Bauerntums des Landadels nicht der historischen Wirklichkeit und künftigen Entwicklung Rußlands entsprach. Daran konnte weder Turgenev in seiner slavophil-agrarromantischen Phase noch der "RiehlSchüler" Tolstoj etwas ändern, der ebenfalls den Bauernkittel angezogen und das Land gepflügt hatte ${ }^{110}$. Die Unterschätzung des Industriezeitalters zugunsten des Agrarstaates konnte keinen Bestand haben. Riehl und die Slavophilen sind deswegen von klarblickenden Zeitgenossen früh als wissenschaftliche "Dilettanten" kritisiert worden"11.

Außerdem waren die russischen 'Stände' kaum mit der ständischen Ordnung Westeuropas zu vergleichen ${ }^{112}$. Nach $1861 \mathrm{kam}$ es in Rußland nicht zu einer Homogenisierung der Adelsschichten und -funktionen, sondern zu einer verstärkten Differenzierung in Beamtenadel, Adelsintelligenz, Landadel u.s.w. ${ }^{113}$. Möglicherweise hatte Turgenev bereits diese Funktionsteilung im Blick, als er im Romanepilog nach einem Zeitsprung von acht Jahren in einem Schlußtableau den kinderlosen Lavreckij mit der jungen Generation des Kalitinschen Hauses konfrontierte. Von diesem heißt es ausdrücklich, es sei zwar "alles verändert", doch zugleich in Ordnung gebracht - "gnezdo ne razorilos' " (289) -, und die Erben werden als fröhliche, aufgeschlossene Jugend beschrieben ${ }^{114}$. Lenočkas

$110 \mathrm{Vgl}$. hierzu das Gemälde von I.E.Repin Pachar'. L.N.Tolstoj na pałne aus dem Jahre 1887. Siehe dazu M.B.Milotvorskaja, Tolstoj I Repin, in: L.N.Tolstoj i izobrazitel'noe iskusstvo. Sbornik statej, pod red. M.M.Rakovoj, Moskva 1981, S. 6690 , bes. S. 83 .

$111 \mathrm{Vgl}$. dazu Thiergen 1978, S. 128-136.

$112 \mathrm{Vgl}$. zur ersten Orientierung die Stichwörter "Adel", "Bauern" und "Stände" im Lexikon der Geschichte RuBlands, hrsg. v. H.-J.Torke, München 1985.

$113 \mathrm{Vgl}$. hierzu R.Th.Manning, The Crisis of the Old Order in Russia. Gentry and Government, Princeton/N.J. 1982. Vgl. auch A.J.Mayer, Adelsmacht und Bürgertum. Die Krise der europäischen Gesellschant 1848-1914, München (dtv) 1988, S. $120 \mathrm{ff}$. - Im übrigen war auch die Beurteilung des Bauerntums verfehlt. Noch Gor'kij muBte später feststellen, er habe trotz angestrengter Suche den in der russischen Literatur des 19.Jahrhunderts idealisierten Bauern "nicht gefunden", statt dessen aber "ein Milieu von Halbwilden" angetroffen, vgl. M.Gor'kij, O russkom krest'janst ve (1922), deutsch zuletzt in: Ruscen in Berlin, hrsg. v. F.Mierau, Leipzig: Reclam jun. 1987, S. 117-132.

114 Bei der Beschreibung des Kalitinschen Hauses und seiner Bewohner (288-293) dominiert das Wortfeld "jung/Jugend" (mit den Varianten "neu" und "Verānderung"), was Lavreckijs Verteidigung der "Jugend" Rußlands und seiner "neuen Menschen" im Streitgespräch mit Panşin (232) wieder aufnimmt. 
Bräutigam ist Offizier, und ihr Bruder hat gerade in Petersburg geheiratet. Sofern die neue Generation zu ernsthafter Tätigkeit findet - allerdings nur dann: "a vam nadobno delo delat', rabotat' " (293) -, wird der russische Adel innerhalb und außerhalb seiner "Nester" einen Platz in der Gesellschaft einnehmen. Die mit Vasil'evskoe, dem Kalitinschen Haus und sogar mit Petersburg verbundenen Lebensformen erhalten am Ende des Romans - als symbolische Signaturen für Dorf, Provinzstadt und Metropole - eine je eigene Berechtigung; nur Varvaras absentistische Existenz in Paris unterliegt einer bleibenden Verurteilung. Daß bei all dem die Rolle des Landadels auch später nicht gering geachtet wurde, zeigte noch 1881 Fürst A.Vasil'čikov, der seinem Buch Sel'skij byt $i$ sel'skoe chozjajstvo $v$ Rossii das Lavreckij-Wort "Pachat' zemlju - i starat'sja kak možno lučše ee pachat' " als Epigraph voranstellte. Turgenev selbst hat das Pflug-Bild im Motto zu seinem letzten Roman Nov' (1877) erneuert - hier allerdings nicht in konkreter, sondern in übertragener Bedeutung ${ }^{15}$. Gleichwohl zeigt sich auch hier jene Konstante in Turgenevs Romanschaffen, deren Anliegen darin bestand, für die russische Gesellschaft und ihr Handeln "Neuland" zu erschließen.

115 Zum Motto von Nov' vgl. Brang 1977, S. 117, sowie Budanova 1987, S. 165 f. 


\section{Literaturverzeichnis}

Antonova 1962

Batjuto 1972

Bezobrazov, V. P.

Ders.

Ders.

Ders.

Borkowsky 1903

Brang 1977

Budanova 1987

Chomjakov, A.S.

Čudakov 1987

Den 1968
G.N.Antonova, Černyševskij i Turgenev o "lišnich ljudjach" (1859-1863 gg.), in: Černyševskij sbornik 3, Saratov 1962, S. 92-106.

A.I.Batjuto, Turgenev-romanist, Leningrad 1972.

Materialy dlja fiziologii obščestva. W.H.Riehl, Die Naturgeschichte des Volkes... (Estestvennaja istorija naroda. Soč. Rilja), in: Russkij Vestnik 1857, Nr. 9-10, S. 657-720, und Nr. 11-12, S. 493-538.

Materialy dlja nauki ob obščestve $\mathbf{v}$ Germanii. Naturgeschichte des Volkes von Riehl, Land und Leute, in: Russkij Vestnik 1858, Nr. 3-4, S. 218-271.

O soslovnych interesach. Mysli i zametki po povodu krest'janskogo voprosa, in: Russkij Vestnik 1858, Nr. 9-10, S. 76-102.

Materialy dlja fiziologii obščestva v Germanii, Moskva 1858.

E.Borkowsky, Turgenjew, Berlin 1903 (=Geisteshalden, Bd. 43).

P.Brang, I.S.Turgenev. Sein Leben und sein Werk, Wiesbaden 1977.

N.F.Budanova, Dostoevskij i Turgenev. Tvorčeskij dialog, Leningrad 1987.

Zametka, in: Russkaja Beseda 1858/II, Smes', S. 216-221.

A.P.Čudakov, O poètike Turgeneva - prozaika (Povestvovanie - predmetnyj mir - sjužet), in: I.S.Turgenev $\mathrm{v}$ sovremennom mire, pod red. S.E.Šatalova, Moskva 1987, S. 240-266.

T.P.Den, Zapiska Turgeneva 1857 g. o krepostnom prave, in: Turgenevskij sbornik IV, Leningrad 1968, S. 107-144. 
Dudek 1988

Dudzinskaja 1986

Erofeev 1988

Febvre 1988

Geramb 1954

Golovanova 1968

Granjard 1960

Ders. 1966

Grigor'ev 1967

Hildermeier, $\mathrm{M}$.

Ders.

Katkov, M. N.
G.Dudek, Textaufbau und Bedeutungsebenen in I.S. Turgenevs Roman "Ein Adelsnest", in: Iwan Turgenjew und die russische Klassik in der Gegenwart. Hrsg. v. K.Dornacher u.a., Magdeburg 1988, S. 13-20.

E.A.Dudzinskaja, Slavjanofily na stranicach gercenovskich izdanij, in: Revoljucionnaja situacija v Rossii v seredine XIX veka: Dejateli $\mathrm{i}$ istoriki, Moskva 1986, S. 75-85.

V.V.Erofeev, "Francuzskij èlement" $v$ poème "Mertvye duši", in: Russian Literature XXIII (1988), S. 201-224 [= Dass. in: Izv. AN SSSR. Serija lit. i jazyka $47(1988 / 1)$, S. 2642].

L.Febvre, Zur Entwicklung des Wortes und der Vorstellungen von "Civilisation", in: Ders., Das Gewissen des Historikers. Hrsg. und aus d. Französ. übers. von U.Raulff, Berlin 1988, S. 39-77.

V.v.Geramb, Wilhelm Heinrich Riehl. Leben und Wirken (1823-1897), Salzburg 1954.

T.P.Golovanova, "Neskol'ko myslej o sovremennom značenii russkogo dvorjanstva". Neokončennaja stat'ja Turgeneva, in: Turgenevskij sbornik IV, Leningrad 1968, S. 155-162.

H.Granjard, Ivan Tourguénev, la comtesse Lambert et "Nid de seigneurs", Paris 1960.

Ivan Tourguénev et les courants politiques et sociaux de son temps, Paris ${ }^{2} 1966$.

A.Grigor'ev, I.S.Turgenev i ego dejatel'nost'. Po povodu romana "Dvorjanskoe gnezdo", in: Ders., Literaturnaja kritika, Moskva 1967, S. 240-366.

Bürgertum und Stadt in Rußland 1760-1870, Köln/Wien 1986.

Das Privileg der Rückständigkeit, in: Historische Zeitschrift 244 (1987), S. 557-603.

Zametki, in: Russkij Vestnik 1857, Nr. 1-2, Sovr. letopis' (kn. 1), S. 1-7. 

V.P.Bezobrazov (Iz neizdannoj perepiski), in: I.S.Turgenev. Voprosy biografii i tvorčestva, Leningrad 1982, S. 5-8.

Lepenies 1985

W.Lepenies, Die drei Kulturen. Soziologie zwischen Literatur und Wissenschaft, München/Wien 1985.

Nierle 1969

M.Nierle, Die Naturschilderung und ihre Funktionen in Versdichtung und Prosa von I.S.Turgenev, Bad Homburg/Berlin/Zürich 1969 (= Frankfurter Abhandlungen zur Slavistik, Bd. 11).

Nikitina 1987

N.S.Nikitina, I.S.Turgenev nakanune razryva s "Sovremennikom", in: Russkaja literatura 1987/3, S. 151-157.

Riehl, W. H.

Die Aristokratie in ihrem socialen Berufe, in: Deutsche Vierteljahrs-Schrift 1851, Heft 2, S. 152-196.

Ders.

Ders.

Schapiro 1978

Die bürgerliche Gesellschaft, 3.Aufl., Stuttgart/Augsburg 1855.

Land und Leute, 3.Aufl., Stuttgart/Augsburg 1856.

Thiergen 1978

Ders. 1980

L.Schapiro, Turgenev. His Life and Times, Oxford 1978.

P.Thiergen, Wilhelm Heinrich Riehl in RuBland (1856-1886). Studien zur russischen Publizistik und Geistesgeschichte der zweiten Hälfte des 19.Jahrhunderts, Gießen 1978 (= Bausteine zur Geschichte der Literatur bei den Slawen, Bd. 11).

Turgenevs "Rudin" und Schillers "Philosophische Briefe", Gießen 1980 (= Vorträge u. Abhandlungen zur Slavistik, Bd. 1).

Ders.

Nachwort zu: Iwan S. Turgenjew, Romane. Winkler Weltliteratur, München 1987, S. 673692.

Zabel 1884

Zaborova 1982

E.Zabel, Iwan Turgenjew. Eine literarische Studie, Leipzig 1884.

R.B.Zaborova, $\mathrm{K}$ sud'be zapiski Turgeneva ob izdanii žurnala "Chozjajstvennyj ukazatel'", in: I.S.Turgenev. Voprosy biografii i tvorčestva, Leningrad 1982, S. 212-216. 
0051698

Anhang 
Im Anhang sind einige Texte abgedruckt, die - mit Ausnahme Turgenevs - schwer zugänglich sind und auf die ich mich in den voranstehenden Ausführungen mehrfach bezogen habe. Sie sind Dokumente der russischen Riehl-Rezeption sowie (vor allem bei Bezobrazov) der Diskussion über die Ständefrage.

Die Texte von Katkov bis Turgenev sind mit durchgehender Paginierung versehen; der Aufsatz von Bezobrazov ist neu paginiert. Auslassungen sind mit [...] gekennzeichnet. Frau Greta S. Isaakjan danke ich für die Herstellung der Druckvorlage.

Peter Thiergen 
M. N. Katkov, Zametki. Aus: Russkij Vestnik 1857, Nr. 1-2, Januar, knižka pervaja, Rubrik "Sovremennaja letopis' ", S. 1-7

В прошлом году литература наша значительно оживилась. Появился целый ряд вопросов, более или менее определённо выраженных, подавших повод к более или менее горячей полемике. Обсуждался вопрос о воспитании; подвергался горячим и ожесточёнңым спорам вопрос о свободной торговле; далее, поднят был вопрос о народности в науке; о сельской общине и сельском хозяйстве в России. В европейской публицистике прошлого года, интересный вопрос возбуждён был графом Монталамбером в его книге о политической будущности Антлии, вызвавшей в нашем журнале две статьи, не совсем мехду собою согласные в точках зрения. Бопрос о централизации есть в настоящее время вопрос первой важности в современной публицистике. Он, как и другие важные вопросы, не может быть решён сплеча, а требует постепенного и внимательного, зоркого рассмотрения, при котором неизбежны односторонности; ибо, при постепенном и серьёзном рассмотрении дела, каждая его сторона требует иногда всего человека, которьй своею односторонностью вернее содействует к достижению ближайшего к истине результата, нежели фантазирование о всех сторонах предмета, когда не видишь перед собою в действительности ни одной. Несравненно важнее Монталамберова сочинения об Англии-сочинение дру- 
гого французского публициста, уже столь известного своим трудом о северо-американской демократии, графа Токвиля: l'Ancien Régime et la Révolution. Aвтор, опираясь на подробнейше исторические исследования,открывшие много нового, показывает, до какой напряжённости доведено было общество во Франции насильственною и искусственною централизациею, которая господствовала в истории этой странн, и которой необходимым последствием бшл страшный взрыв, заключивший собою прошедшее столетие.Во французской революции автор видит не только последствие, но даке прямое продолжение этой системы централизации; это роновое событие является у Токвиля самым крайним её выражением. Труд знаменитого публициста отозвался во всей европейской курналистике. Французская централизация представляет в выстей степени интересное явление, и мы надеемся, по поводу книги Токвиля, представить в "Русском Вестнике" попытки к разъяснению этого важного исторического факта. Ограничимся теперь кратким замечанием об относящихся сюда понятиях. Централизация и государство в сущности одно и тоже. Истинно человеческое общество невозмолно без посредства государственного начала. Воображать себе человеческое общество, при даннх на земле условиях, без государстваочень можно, но такое представление будет не более как утопия, не более как мечта.Какую бы форму ни имело государственное устройство, оно неизбежно. Только то оощество процветает, только там человеческая хизнь раскрывается во всей полноте и разнообразии своём, где государство дело 2 
решённое, где оно существует бесспорно. Но тем не менее, государство, в собственном и тесном смысле, не есть нечто непосредственно данное в жизни народа. Оно покупается дорогою ценою. Установлению государства предшествует, как мы видим в истории, завоевание или внутреннее брожение, война всех против всех, по выражению Гоббеса, или, как выразился наш летописец, восстание рода на род. То время в кизни народа, которое предшествует появлению государства, есть так назьваемая эпоха доисторическая, от которой остаются лишь смутные племенные предания, отголоски народных верований и наконец язык.Но в этом отношении история натего народа представляет особенное и весьма замечательное явление. Существенны смысл, главный интерес истории древней Руси, есть образование государства, централизация, "собирание земли". Честь и слава новейтей исторической школе нашей за то, что она обратила особенное внимание на раскрытие этого смысла нашей древней истории. Трудно и медленно принималось государство на нашей народной почве, трудно и медленно собиралась Русская земля.Что для большей части других народов было делом доисторическим,делом забытым, то происходило в хизни нашего народа на памяти истории. Сначвла была усобица между родами, и варяхская дружина принесла семя государства в дебри и пустыри нынешней России, тогда не имевшей никакого названия, не составлявшей никакого единства, скудно, изредка заселённой различными племенами. Потом следует усобица между множеством княхения, между множеством дружин, на которые распалась первоначвльная 
варядская друхина. Далее видим мы, как всё стягивается к одному центру, как возникает Московское царство. Здесь предстоит нам государство, но государство в неустоявшейся, несозревшей форме, тот вид государства, в котором собственно государственное находится в неорганическом, смутном смешении со всеми другими формами человеческой жизни, то отделяясь от них, то снова сливаясь с ними.

Государство и общество-две различные формы, и признаемся, нам бнло очень странно усльшать недавно, на одном учёном диспуте, сомнение в этом различии, именно теперь, когда в системе натих знаний очищается особое место для новой науки, жадно требуемой умами, когда полагается уже основание для этой науки, имеющей своим предметом общество, и отличной от политики, когда в свмой мизни политические интересн уступают первенство интересам общественны. Мы не модем не упомянуть здесь о блистательном труде по этой части, которым мохет похвалиться германская литература в последнее время: әто Naturgeschichte des Volks, Риля. Риль в настоящее время преподаёт в Монхенском университете история культуры, которая в сущности и есть не что иное как история социяльная, в отличие от политической. "Русский Вестник"посвятит этому предмету и труду Риля цельй ряд статей, над которым уже работает один из напих близких и даровитых сотрудников. Не во всём мохно согласиться с Рилем. Постоянное и столь живое изучвние исторических форм сообщило его мысли модет быть слишком археологическия хараятер. Сердие его всё обратилось к прошедшеку и всё пре- 
далось историческому интересу;он нередко забывает для них интерес современного и требования будущего. Но зато какою жизнью пьтат его очерки!Учёный в нём живёт дружно с художником. Во многих отношениях Риль дале больше художник,нежели мылитель.Во второй половине прошлого года вышли в свет его рассказы из истории общественного бнта, culturgeschichtliche Novelien, с которыми тоже не преминём мы познакомить напих читателеи. I...I 
T...k (= A. S. Chomjakov), Zametka. Aus: Russkaja Beseda 1858, Nr. 2, Rubrik "Smes' ", S. 216-221

В числе занимательных и серьёзных статей, нередко появлямихся в Русском Вестнике, замечательны две статьи об одной немецкой книге, сделавшей сильное впечатление в своём отечестве, о книге Риля "Естественная История Народа". Одна из этих статей подписана Г. Безобразовым, другая г. Соловьёвьм. Фактическое содеркание книги, т.е., изучение жизни немецкого народа особенно в его сельском быте, мало изменённом современным просвещением,-вот на что по преимуществу обратил своё внимание Г.Безобразов, и о чём он дал русскому читателю весьма удовлетворительное понятие посредством удачно внбранғых отрывков и собственных выводов. Направление книги, т.е., протест в пользу естественной жизни народов и против искусственной қизни государственных обществ,-вот на что обратил своё внимание г.Соловьёв, и о чём он вовсе не даёт никакого понятия, несмотря на некоторуто ловкость в полемическом приёме.

Странно, что историк. не уразумел: исторического значения того умственного явления, которое он подвергает своей критике; и что он не спросил у себя отчёта в естественности и след. исторической законности протеста учёного немца в пользу неучёных немецких селян. Ещё страннее что все протесты против современных им общественных 
устройств он думает объяснить просто, как восстания против прогресса вообще; а восстания эти ещё проще обънснет, как признак бессилия утомлённого трудом общественного развития. Примерами у него являются Платон и Морус. Легки и приятны такие обобщения, особенно свойственные Французским писателям: жаль только, что они почти всегда столь же обманчивы, сколько и легки. Не станем рассматривать, во сколько прав Г. Соловьёв на счёт Платона и Моруса/хоть и тут дело крайне сомнительно/; но, если они протестовали против современных обществ и сделались врагами прогресса вследствие бессилия и утомления,-что же? Неужели Овен, С.Симон и Фурье, также протестовавтие, также утописты, действительно были сознательными врагами прогресса? "Но",-скахут-"они не ищут идеала в старине исторической":да в какой же исторической старине искали идеала Платон и Морус? Обълнения г.Соловьёва вовсе несостоятель ны. Но всего страннее то, что историк, сводя исторические явления под один закон, даже и не замечает их прямого противоречия мехпу собою. Платон, как и Морус, как и все следовавшие их путём, чистые априористы; они созидают несуществующее общество из стихи вообрапаемы. Риль и школа, к которо он принадлекит, отправляются от наблюдений чисто әмпирических и хотят ощивить общество посредством восстановления прав, утраченнх одною из общественнах же стихй, дөле не определяя/хотя и стараясь угадать/ пути, по которњ пойдёт дальнейтее развитие. Что хе тут общего? Очевидно тот, кто не мог понять самого явления, 
не может понять и причины его.

Весь разбор Риля г.Соловьёвьм получил свой характер от этих ошибок. Он заклочается в отдельно выдернутых Фразах,да в возралениях, в которых ловкое пересыпание общими местами заменяет дельни разбор, но в котором сверх того, к сожаленио, часто проскакивает явное непонимание того, на что возрахается. Так напр., Риль говорит: "во многих местах северной Германии/и Скаңдинавии/ кахшы крестьянски дом имеет свой знак, и этот домовыи знак, так хе дорог для крестьянина, как герб для дворянина. Но медпу ними большое различие: крестьянская семья, переменяя двор/что, нонечно, случается редко/ переменяет и свой домовой знак, тогда как герб дворянина привязан к фамилии и от фамилии переносится уже на замок; герб не есть знак владения, но знак рода, тогда как крестьяне берут свой знак прямо от дома". Автор предпочитает этот домовой знак дворянскоку гербу: что хе возрахает критик?Он предпочитает герб знаку крестьянскоиу и оправдывает своё прещпочтение следующи пояснением. "Автор не хочет понять всп вахность этого различия: при первоначальных формах, господствуоцих в земледельческом сословии, материальное, дом господствует и подиннет себе человека и его человеческие отношения: человек, семья не имеют своего знака, и отмечак всё знаком своего господина-дома, тогда как в другой сфере, род, чисто человеческое отнотекие, преобладает, человек есть господин своего дома, и отмечает его своим родовњм знаком: Критик не понял, что дом селянина 
обозначается знаком потому, что он есть основа и в тоже время символ общественных прав и обязанностей домохозяина /au bourgeois ayant pignon sur rud;он не понял, что дом есть единица и в смысле нравственного союза семейства, и в смысле общественного устройства hof в быту земледельческом, maison в смысле торговом/ и вообразил какую-то зависимость человека от камня, обозначеннуо тавром.Он так же не заметил, что герб родовой есть знак прав и обязанностей личных, основаннх на чисто материальной передаче крови. В таких промахах нельзя не признать порядочной доли комизма, а подобных промахов довольно; но мелкие и частные ошибки исчезајт в общем непонимании и уже не заслуживают отдельного указания.

Главный характер, избранный г. Соловьёвым в последнее время: это характер рыцаря прогресса. Едва заслышит он, что где-то высказалось слово, оподозривакщее иистоту прогресcа,

Не дождавшися дня, он седлает коня, Надевает доспех боевой-

и в поход, в поход! Вероятно, от того-то иногда, торопясь к битве в потёмках, он вовсе и не туда попадает, куда хотел бы попасть. Бесспорно, стоять за прогресс- дело похвальное; но, во-первых, надобно точно быть уверенны, что кто-нибудь вооружается против прогресса, а во-вторых надобно себе задать вопрос: чей прогресс? прогресс чего именно? Иногда можно бы подумать, что по мнению г.Соловь- 
ёва, всё, что случилось в известных географических пределах годом позже, есть уле прогресс против того, что было годом раньше, и что завоевание Константинополя турками есть прогресс Греческой области. Иногда он как будто осторожнее и считает прогрессом только явления жизни, исходящие из внутренности самого общества. Тогда выходит, что вся жизнь Римской Империи до её последнего дня была прогрессом; что от Болеслава Великого до самого раздела вся щизнь космополитски просвещённой Польши была прогрессом, и что прогрессом должно называть движение любой страны, несколько развиваљщей у себя грамотность и централизация, хотя бы она в то же время отнимала у большинства своих членов дале значение людей, и т.д., и т.д. Вот что выходит из одной простой недогадки, из того,что историк наш никогда не задал себе вопроса: прогресс чего? Может усовершенствоваться наука, а нравы могут упадать и страна гибнуть. Может разграфляться апминистрация и след. по-видимому приходить в порядок, а народ упадать и страна гибнуть. Может скрепляться случайный центр, а члены все болеть и слабеть и страна опять таки гибнуть. Где же тут прогресс страны, несмотря на действительны, мохет быть, прогресс некоторых проявлений человеческого разума? Прогресс есть слово, требующее субъекта. Без этого субъекта прогресс есть отвлечённость или, лучше сказать, чистая бессмыслица. Риль и ему подобные такще друзья прогресса; но они хотят, чтобы прогресс был прогрессом существ қивых, а не отвлечённостей. Для господина хе Соловьёва существа 
живые сами по себе/Бог с ними!/,a прогресс сам по себе, и ему вовсе не нужно спрапивать:чей именно прогресс.Это не простая догадка, но прямо выходит из слов его в этой же статье:"тот же самый прогресс в языке, от сднозвучия животных до членораздельных звуков человеческих." Что әто такоепрогресс в языке? Усовершенствование языка? Какой же собственно язык совершенствуется? Мы говорим: русский, или немецкий язык совершенствуется,-это значит, что народ, люди, говорящие этим языком, преемственным трудом усовершенствуют свою речь. А тут, где же преемство? Где субъект выражалий себя в языке? Или совершенствуется орган, произносящий звуки-глотка,-от животного до человека? Скорее до попугая, которого глотка уже способна к членораздельным звукам; но едва ли:"погинька, попинька: дай попиньке чаю!" есть усовершенствование против пения соловья. Очевидно, мысли автора предстоит идея другого прогресса, прогресса не только в физической организации глотки /что относилось бы и к попугаю и к полному кретину, у которого органы способны к произношению членораздельному/, а в общем организме и во взаимодействии мозга и звуковых органов, т.е., не только в возможности вырашаться, но и в побухдениях к вырахению. Тогда спряпивается, о чём же говорит Г.Соловьёв? О том, что какой-то вещественно-дУховный организм, т.е., отвлечённая идея вещественно-духовного организма находится в состоянии прогресса от животного до человека. Или это вовсе не имеет никакого смысла, или это имеет смыл только в мистико-рационалисткой телеологии 
учения об абсолютном духе, который стремится постепенно к усовершенствованию своего самопредставления и своего самосознания. Я ничего не говорғо против этого учения, ибо ○ нём не приходится говорить так-вскользь; но думаю, что г.Соловьёв вовсе не принадлежит к его последователям. И вот куда попадает учёный при неосторожном употреблении слова, о котором он себе не даёт ясного понимания. Пусть он предоставит это французам! Пусть они ратуют за слова без мысли! Ведь это своего рода растление ума человеческого.

Главная же причина ошибок Г.Соловьёва при его критике на Риля состоит в том, что, говоря о Риле, он думает о своих мнимых противниках на святой Руси. Он уже пробовал их назвать антиисторической школою: не удалось, не не пристаёт. Г.Чичерин попробовал их прозвать мистиками; но все догадались, что это просто вырахение собственного непонимания $\Gamma$.Чичерина/это дахе объяснила Молва/: теперь г.Соловьёв пробует, не удастся ли слово буддаисть. Рвзумеется, оно не удастся, да сверх того и выбрано очень странно. Ведь в крайне неисторической стране, Индии, будшизм один только и пробудил историческуто стихию. Все летописи тамошние-Сингалезские, Катемирские и др. принадлежат буддизму. Самое время Готамы есть наилучше определённая из древнеинұииских әпох/Шаңдра-Гупта и Викрамадития позже и отчасти определяотся такле по история будда изма/. Выбор очевидно неудачен.Быть может г. Соловьёву 
эти обстоятельства неизвестны. Дивиться нечему: общая история не его специальность, но он может нам тут поверить на слово, а пожалуй хоть и справится-не беда. Как бы то ни было, он очевидно пелает намёками нападать на своих русских противников. Эти противники ему выразили откровенно своё мнение о его трудах и направлении. Пусть бы он отвечал прямо! Правда, что намёками легче; но такме ли оно хороmо?

И неужели он в их направлении предполагает видеть выражение утомлённого бессилия и боязнь крепкого труда? Он очень ошибается. Легче и несравненно легче давать себя увлекать течению, чем стараться отклонить самое течение в лучшее русло. Работа мыслящего ума тякелее работы пишущей руки: тот, кто в современной, подспудной жизни народа и в непонимаемой, хотя и описываемой, старине отыскивает те живые стихии, те умственные типы, в которых заключается и прошедший идеял и развитие будущей судьбы народа, трудится много более, чем тот, кто /как многое мнолество людей/

\section{Бессилен к смелому возврату \\ Иль шагу смелому вперёд; \\ И по углахенному скату \\ Лениво под гору ползёт.}

Всего желательнее было бн, чтобы г. Соловьёв узнал, наконец, в мнимых противниках истинных доброжелателей, которых цель дахе в критике- навести его на такой путь, на котором его дарования могли бы принести добрые плоды. 
Pis'ma $P$. V. Annenkova $k$ I. S. Turgenevu. Aus: Trudy publičnoj biblioteki SSSR im. Lenina, vyp. 3, 1934, S. 45-184.

Brief Annenkovs vom 9./21.7.1859 aus Simbirsk: (S. 81-82)

I... I Просите вы сведений об отечестве. Лучшая книга o современной России, какую я знаг, написана Фридрихом Давидом Страусом и назнвается:Ульрих фон Гуттен. Я нњнче прочёл её в деревне и вам рекомендуо. Это изумительно, как Немец өтот понял личность Белинского, большей части напих деятелей, их отношения мехпу собой и к общественны современны вопросам и, наконец, какую удивительную охивлённую картину представил борьбы пробуддённых сил напих, их падения в әпоху первой стычки, нового возникновения, указав дахе, что с ним случится в близком будущем. Вот биография. Говорят-явления не повторяотся,да человек-то повторяется. Я нахощусь под таким влиянием Гуттена, что убедительно проту вас отискать мне за границей хороший портет әтого Виссариона Григорьевича из рыцарей и подарить мне:я әаплачу что нудно. Страус дахе и Вас знает, да и всех нас знает. Правда, мы отралаем его великолепни лаңшафт в маленьком и миленьком виде камеробскуры, быстро передвигаем нодки там, где у него слшатся шаги,суетимся на полотне без шука, в мёртвом молчании, мехну тем как у него раздалотся громы исторических события, но всё 
же это один и тот же лаңпшафт и одни и те же люди.

Другая книга, написанная об России, есть известная: "Land und Leute" Риля. Прочтите и эту непременно. Основная мысль её-создать правительственную и социальную науку об изучении коренных свойств каддого племени и народа, на душе того и другого, на неотделимых и неизвратимых их стремлениях-есть русская мысль, которая одна и составляет единственну: политическую религию для нас, внеправительственнх лиц. Правда, мы о своих племенах и народах знаем поменее того, что знает Риль о своих, у которого характеристика различного немецкого быта ухе является глубокой, психологической и художественной картиной, но вот что он украл из России. Он говорит, что изучение народных стремлений есть консерватизм, а пренебрехение этой науки и постройка общества на кабинетных соображениях принаплежат либерализму и что поэтому государство, не имеющее консервативных начал, не имеет будущности, так как оно не может знать ни себя, ни путей, ему предстоящих. Он до того простирает дерзость покражи, прикрывая себя только именем Франции, что просто у нас с языка выхватывает афоризмпорядочному человеку стыдно в напе время называться либералом! I...I 
Brief I. S. Turgenevs an Annenkov vom 1./13.8.1859 aus Courtavenel:

I...I Риля я читал с насләждением и с чувством, подобным вашему чувству, хотя по временам честил его филистером. Гуттена по вашей рекомендации прочту и привезу вам его портрет.I...I 


\author{
В.П.Безобразов \\ 0 сословных интересах.
}

Мысли и заметки по поводу крестьянского вопроса

Aus: Russkij Vestnik 1858, Nr.9-10, S.76-102 
(n)

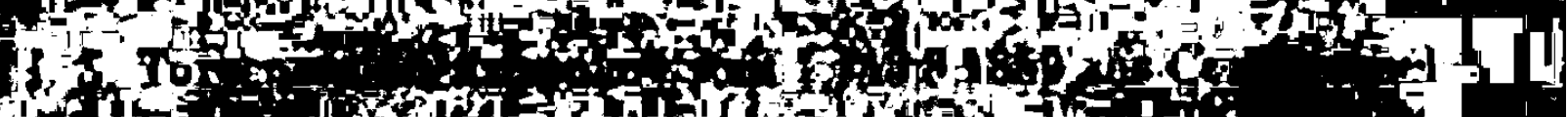
A

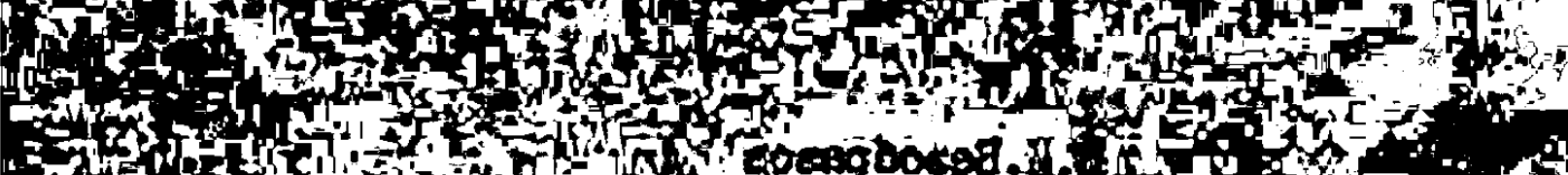

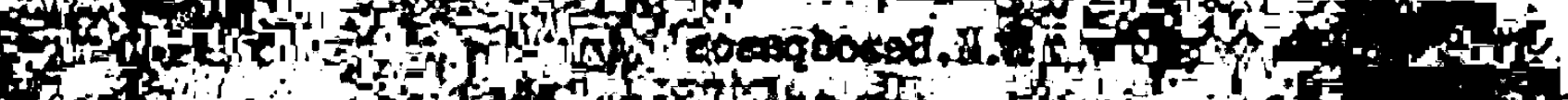

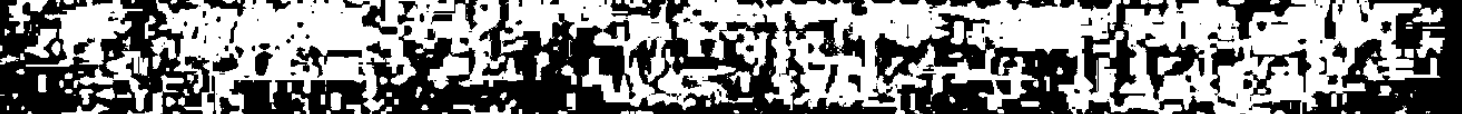

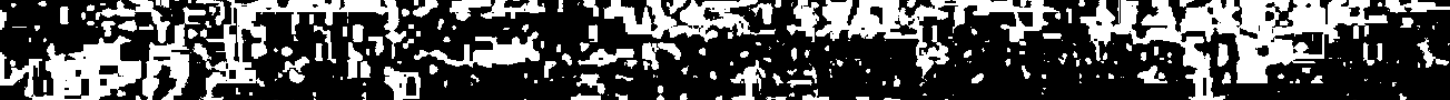

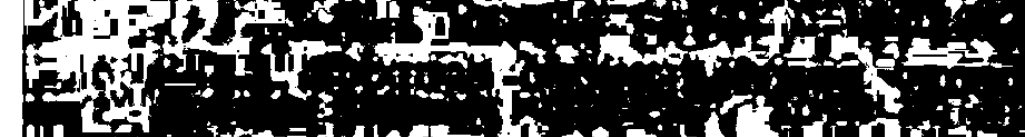

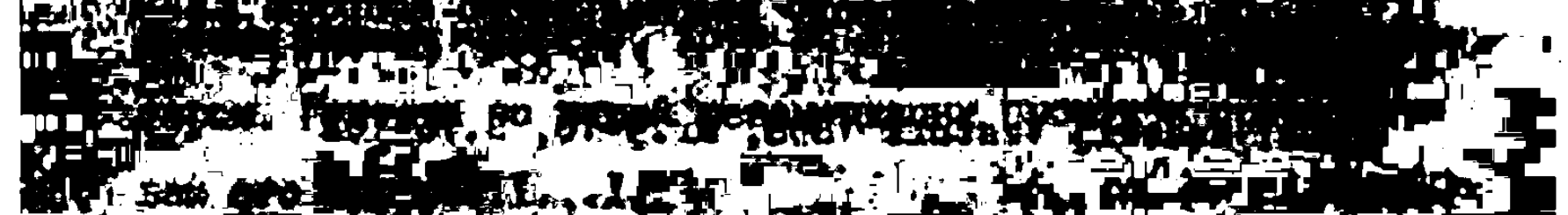
(1)

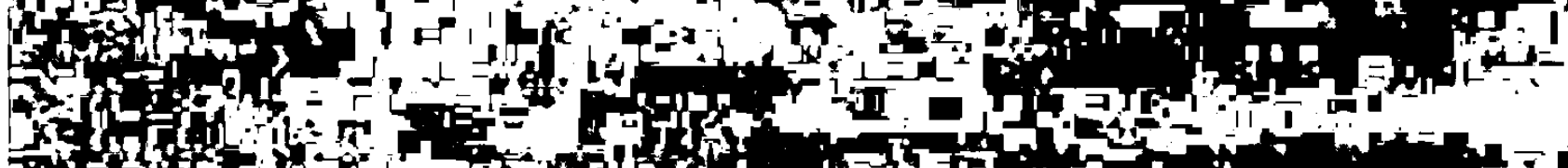

$\Rightarrow$ ind

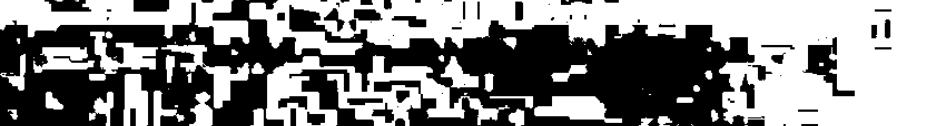

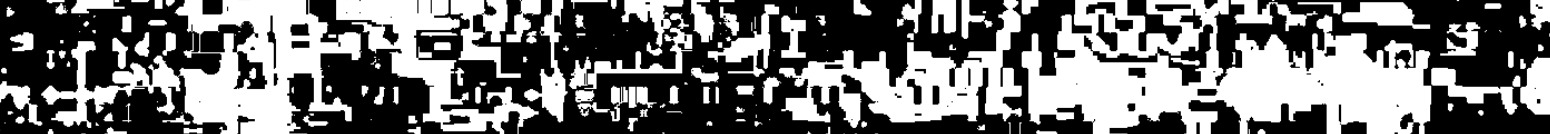

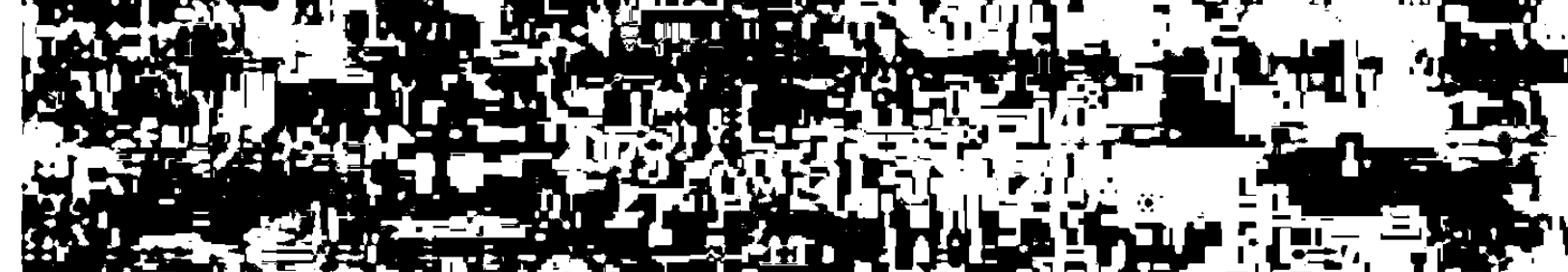

P. (a) 19. 1) (1)

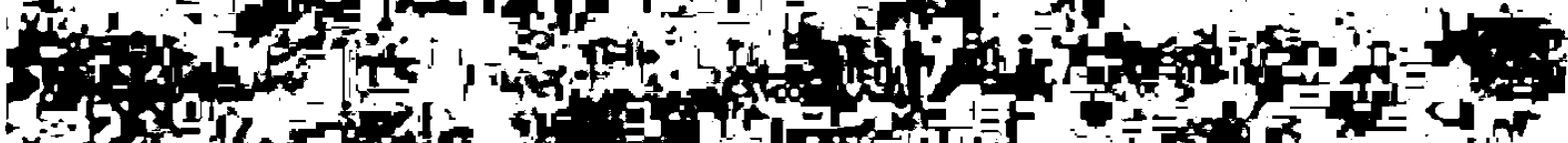

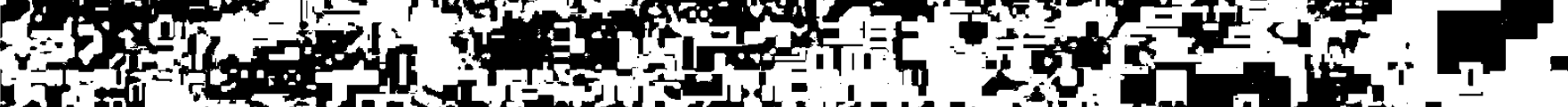

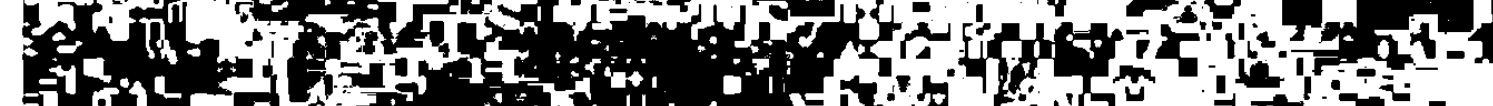

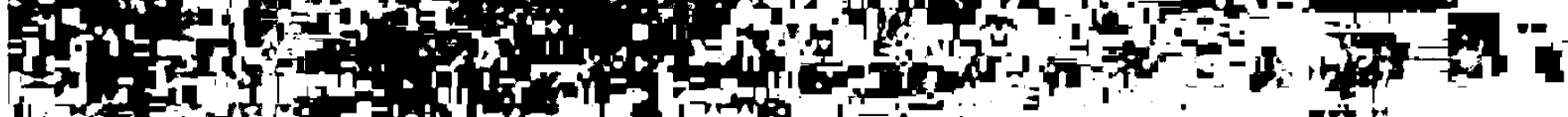
1) (3)

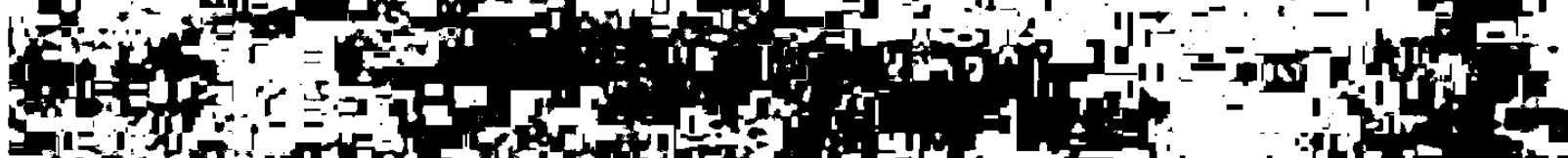
1 (1)

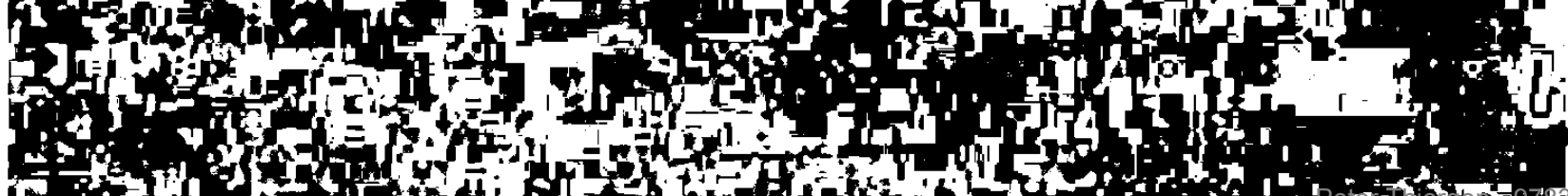

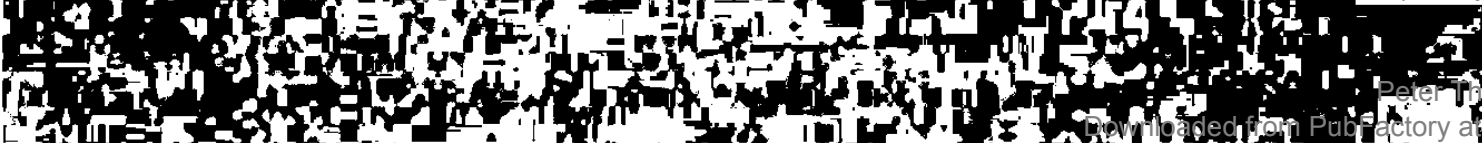
a 
Великая реформа, совершающаяся вокруг нас, обняла в самое короткое время всю умственную деятельность нашего отечества. Всякий считает себя обязанны принести на народное дело всё его умственное достояние. И это побуждение самое естественное. О степени пользы своего посильного участия никто не может судить; но всякий хочет быть чист перед своею совестыю, поделившись с обществом процентом с того нравственного калитала, который приобретён в личное владение кақдого, только с помощью всеобщих усилий всей прошедшей и настоящей жизни народа. Это последнее побуждение облегчает труд говорящего перед публикой. Mы имели его в виду и в напем намерении сообщить некоторые мысли по поводу крестьянского вопроса.

В письме нашем к С.T. Аксакову, помещённом в последней книжке Русского Вестника I, мы говорили о самых общих чертах совершающейся реформы. Мы выставили её идеальний и вместе с тем чисто практический характер, и заявили желание, чтобы разрешение её было гармоническим соглашением всех затрагиваемых ею общественны интересов. Теперь мы намерены ближе вникнуть в эти именно интересы, затронутые реформою.На первом плане представляются сословные интереси.

Не только у нас, но и в западной Европе сущность и взаимные отношения сословий привлекают $\mathrm{k}$ себе с некоторых пор особенное внимание литературы и публицистики. В настояшее время изучению истории и общественного и по-

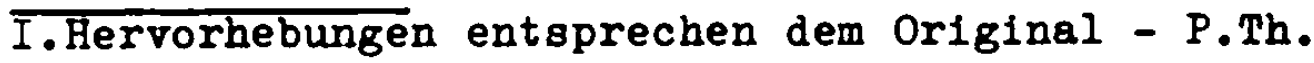


литического значения сословий посвящены многие весьма замечательные труды европейских учёных, преимудественно в Германии. Завоеванием космополитического духа идей XVIII столетия явилось могуцественное противодействие со стороны народностей и исторических общественных формаций. Многие попытки обобщения со стороны горделивой идеи естественного права людей и общечеловеческого просвещения сокрушились во прах перед различиями расы, хозяйства и воспитания. Различия в быте, во всех нравственных воззрениях особьх классов одного и того же общества оказались столь глубоко укоренившимися во всех условиях умственной и материальной хизни принадлежащих им людей, что возникли такие препятствия к подчинению всех классов общества одним и тем же формам политической жизни, каких и не подозревали в слепом поклонении требованиям отвлечённого разума. Препятствия произведены были не старанием нескольких людей, упорно деркавшихся старого порядка, а самою природою вещей, самою жизнью общества, которую никакая внешняя сила не может переделать по своему. Полагали достаточньм объявить всенародно, что нет сословий, и добросовестно убехдены были, что с той самой минуты сословия исчезнут с лица земли. Д конечно не было недостатка в материальной силе, чтобы привести такое желание в исполнение; французский конвент обладал государственной принудительной силой, какой не имело может быть никогда ни одно правительство. Не много прошло времени,- и общественные различия, подавленные силой и могуществом, выступили нарупу и доселе у 
всех народов сохранились не только очертания различных общественных формаций и классов, но и живые, развивающиеся особенности быта и понятий и затем отношений к обществу. Явилась, как естественная, необходимая реакция самой жизни, потребность исследовать эти особенности и дать им законное место и удовлетворение в государственном устройстве. Стали говорить о политияе, основанной не на одних общих началах естественной справедливости и государственной необходимости, но и на действительности той или другой общественной жизни.Реакция, правильная в своём исходном пункте, доходит иногда в своих притязаниях до чудовищнъ размеров. Так образовалась в северной Германии особая партия, стремящаяся к так называемому органическому разделению общества или ни более, ни менее как к подчинению общества окостенельм формам феодальных сословий. Такова партия дворянских недорослей в Пруссии, или юнкеров /Junkerthum/. у нас тоже мелькакот там и сям свои недоросли; но характер их стремлений несколько иной, у них недостаёт многих задатков истории, которыми владеют чулеземные недоросли. Нам говорят о каких-то вотчинных отношениях некоторых родов к остальному народонаселению, о каких-то родовьх привилегиях, но это не искренне; под ту манныи покровами каких-то политических убеждений, высказываемах без всякого твёрдого сознания, без всякой связи с какими-либо преданиями, кроется чисто промышленный, материальный интерес, который бы выиграл гораздо более, если б откровенно выдвигали его вперёд и прямдуушно стано- 
вились под его знамя. Во всякую эпоху найдутся люди, готовые воспользоваться всякой струёй умственного движения для своих исключительно личных интересов, забывая необходимое условие, оправдывақщее проявление личнх интересов, и состоящее в выгоде, извлекаемой из них всем обществом. Такие притязания в свою очередь являотся всегда оторваннњи от исторической почвы. Общественные сословия и классы у всякого исторического народа подлежат бесконечным видоизменениям и бесконечному развитию; в них, как во всех формах народного быта, «ивёт дух всемирной истории, дух общечеловеческого обновления и прогресса. Чтобы понять этот дух, уловить закон его развития, понять идею, влекущую все человеческие общества к разделенио на особенные группы, необходимо вникнуть во все формы, пройденнае идеей в прошедшей деиствительности; но принять какуолибо из этих форм за постоянную, было бы насилием против самой истории.

В постепенном образовании и перерохдении общественнах классов или состояния у всех народов лежит несколько начал, всем им общих и вытекаюцих из самых непреложных законов развития человеческого духа и общественной жизни. Первое условие и первый признак малейшего успеха грақданственности есть разделение труда. Я говорю здесь о разделении труда в самом обширном смысле, а не о том, которое мы видим на фабриках, где один треплет лён, другой промывает его, третий прядёт нитку, четвёрты сучит и т.д. Впрочем и такое чисто промыпленное разделение труда осно- 
вано на тия іе саном :зконе человеческой деятельности, по которому разнеление чястен всякои работы между несколькими лодьми уси:инит производительность калдого человека, и потому увеличиваеч количество работы, совершаемой всеми этими людьми сравнительно с тем её количеством, которое было бы сделано всеми ими, если бы кақшый из них участвовал во всех частях работы или производил всо работу совершенно независимо от других. Но в промњшленности разделение труда только увеличивает и улучшает массу произведений, её последствия технические; в кругу развития всей совокупности общественной жизни, в пространстве и во времени, разделение труда делает возмохны удовлетворение совершенно новых, без него не существовавших, потребностей, видоизменяет целые страны и налравление народов, создаёт исторические эпохи. у кочевьх народов все занятия смешаны, все они одинаковы у калдого человека; лишь только некоторые из них остановились, осели на земной поверхности, то есть занялись преимущественно какой-нибудь одной работой, скотоводством или земледелием, удовлетворением потребности пищи и одеяния для себя и для прочих своих соплеменников, предоставить последним защищать себя и их от внешнего врага; так начинается первая фаза исторического развития народа, первая выделяющаяся эпоха во мраке доисторических времён. Разделение занятий идёт далее; вокруг земледелия и скотоводства сосредотачиванся одни роды, вокруг промышленности и торговли другие; отделяются городские населения от сельских, и исторические судьбы народа быстро подвигалотся 
вперёд.

Некоторые роды занятий, как, например, земледелие и торговля, различием внешних, материальных условий соответствующего им образа жизни дают особенное направление мыслям и чувствам сельского и городского населения, обусловливают собой различное участие кақдого из них в общих народных предприятиях и делах. Различие этих материальньх условий быта тем резче, чем далее восходим мы к младенчеству народов; и тем более сглапивается, чем более мы прибликаемся к эпохе зрелости кахдого отдельного народа и вообще к новейтему времени. Чем менее образован человек, тем зависимее он, как относительно своего образа жизни, так и во всех своих умственньх и нравственных побуддениях, от внешней, материальной обстановки своих занятий. Но независимо от этих личнғх причин, совокупные успехи человечества имеют могущественное влияние на обобщение образа жизни и наклонностей всех групп народонаселения; мы видим, что в настоящее время ежедневно более обобщағтся даже материальные условия различных родов деятельности; системы земледелия непосредственно подчиняются с одной стороны открытиям естественных наук, а с другой стороны требованиям торговли и промышленности; торговля требует с одной стороны строгих сведений в технических производствах, с другой стороны политико-экономических и географических сведений; и всякое учёное предприятие имеет свою промы ленную сторону. К этому ещё надо заметить, что новейшие 
способы сообщения вещей и мыслей, в самом обширном смысле этих слов, выдвигают человека умственно и материально из тесных затворов его рабочей сферы и обобщакт образ жизни во всех родах деятельности. Занятия еледневно более специализируются по препмету, по цели, и ежедневно более обобщактя в средствах, в путях. Мне кахется, что эта черта современной жизни довольно очевидна и крупна, чтобь оправдать мою, может быть, излишнюю смелость так решительно формулировать её как закон общественного развития.

Особенность общественного разделения труда, идущего параллельно с развитием народа, всегда и всоду расчленяющая его на группы, особенность, которая заслуживает преимущественно внимания в истории сословий, это чисто нравственное его значение. Какие бы ни высказнвались әксцентрические воззрения на жизнь человека на земле, какие бы ни проявлялись чудовищне злоупотребления отдельньх лиц силами, данными человеку творцом, но нравственные цели преобладаут и во всей истории человечества, и в современном образованном мире. Они преобладают по воле Провидения и часто преобладают без всякого сознания людей, общественных классов, народов, служащих только конечнњм тленнњм сосудом нравственных начал, пололенньх в основании общечеловеческого просвещения. Лишь только являотся в народе проблески нравственных и умственнах потребностей, является и разделение труда, ибо без последнего невозмодно никакое удовлетворение первьх. Для того, чтоб 
один сложил сказку или песнь, сообразил как защитить границы от врага, куда выгоднее послать произведения своих соседей, разрешил возникшие мелду ним распри, произнёс проповедь, наконец чтоб один мшслил, нумно, чтобн другой изготовил для него съестнше припасы, жилище, одекду. Мысль требует досуга от материально работы; напряление мозга не может происходить в одно время с напряжением мппи. В первуго эпоху истории народа, досуга для удовлетворения умственным и нравственным потребностям нукно ещё более, чем в последуощие, ибо мозг и мшиш работакт труднее, чем менее упрахняот их. Затем при одном роде занятий возможно больше умственного и нравственного развития, чем при другом; одни держат человека в более тесной связи с грубыми силами природы, другие менее. Так распределяется между разньми частями народонаселения труд и с ним умственные занятия и известная степень умственного и нравственного развития, обрацающаяся в принаплехность личностей, родов, цельх частей народонаселения. Вследствие различнх обцественнх обязанностей общество присваевает своим различным членам различные ло качеству и количеству имущества. Разнообразие имуществ развивается параллельно с развитием общества. Как имущество калдого отдельного лица, или совокупность всех принаплежащих ему материальньх сил обеспечивает для него лично возможность досуга, возмохность удовлетворения некоторым нравственны и умственна потребностям, так и имущественне различия в разных группах народонаселения обеспечивают удовлетворение умствен- 
ных и нравственных потребностей в целом народе, обеспечивают народни досуг. Таково значение различия состояний, осмысленное и оправданное законом общественного развития. Лишь только один из классов общества утрачивает из виду свою общественную нравственную задачу, лишь только имущество делается в руках его средством преследования исклочительно своих собственых целей, оторванны от интересов всего общества, от его нравственной, общечеловеческой задачи, тотчас этот общественнй класс терлет своё общественное значение, свою причину жизни, свою органическую связь с прочими классами и обращается в тягость для них. Никакие государственные привилегии не могут заменить внутреннее нравственное содерлание общественного класса, внутренее самопроизвольное в нём сознание его общественного призвания. Присвоение промышленных монополий хозяйствам, распадахиимся от внутреннего беспорядка и бездействия,может только заслонить от ослеплённых своим собственным величием глаз печальную картину разложения в этих хозяйтвах, но рано или поздно этим разложением овладевает общее экономическое двихение страны. Присвоение путём законодательства умственна льгот также не может восполнить внутренною бедность умственных и нравственных сил, и рано или поздно она должна уступить общему умственному движению страны. Независимо от воли членов различнњ групп народонаселения, распределение умственна и нравственњах преимуцеств в народе изменяется под влиянием силы времени и успехов всего образованного общества. Запасн умственњы 
и материальнњ благ ежедневно прирастают в обществе и во всех его слоях; удовлетворение умственны потребностям в кахдом слое постепенно становится независимее от прочих слоёв. Технические усовершенствования всё более и более освоболдают труд человека от напрядения мьшц и дают место воспрянуть в нём высшим побуддениям разума и сердца. С кақпым днём число участников в нравственных и умственных отправлениях общества возрастает.

Указав на некоторые, главнейшие начала образования и развития классов общества, излопу в самом беглом очерке различные формы, которые присваиваются им историей.I...I

Праву рождения, без всякого сомнения, принадлежит ещё и ныне важное значение и в обществе и в государстве. Оно охраняет связь прошедшего с будущим, говорит один из замечательных современнх учёньх и публицистов, Блунили; оно заключает в себе ту непрерывность хизни общественного и государственного организка, которая переходит далеко за пределы қизи отдельной личности. Но где оно царствует над всеми лодскими отнотениями, там изнемогают перед ним все лучшие человеческие силы; там политическая жизнь чахнет, и государство распадается. Конечно, призрак, внешние очертания государства могут ещё долго оставаться, как в Индии, и сохраниться в течении веков, как набальзамированная мумия; но әто только бездушный призрак, В нём нет духа, движения и успеха, охивляющего человеческое общество и дающего прочность и политической кизни. Когда брахманы свокм сверхъестественны и природдённм величием IO 
превосходят всё остальное общество, то как может возникнуть рядом с ними герой или государственный человек с мужественны самосознанием, с решимостьо действовать во имя сил своей собственной личности? Высокомерный брахманский жрец, нимало не заботящийся о благе всего общества, живущий безысходно в мире созерцания, стоит неизмеримо выше таких людей, остаётся несравненно лучшим и благороднейшим существом, даже когда они принесли в жертву обществу все лугшие свои силы и способности.

Система каст не совместима с духом христианской религии и с государственнњми и общественнњми отношениями, устроившимися на его началах. Разделение на касты не может устоять перед постепенно развиваядимся в народе воззрением, что все его члены - дети одного и того же Бога, что все, в одинаковой мере, призваны вкусить благ и горечи жизни.

В истории европейских народов мы находим везде, на месте каст, сословия.Как касты, так и сословия представляются системою органического расчленения народа на несколько составных частей. Но сословия уже не столь окоченелые формации общества, как касты. Они полохительно отличаются от последних уже тем, что подчинились движению истории и имели своё развитие. Уже у европейских народов мы модем заметить самне разнообразные формы для сословных общественнд союзов; эти союзы не неподвимны, но имеют свою историю, богатую внутренним переворотами. I ... I 
I ... I C великими открытиями и изобретениями,ознаменовавшими собою начало истории трёх последних веков, начинается период всеобщего освобохдения мысли, труда и собственности в заладной Европе. В некоторых странах, как в Англии, и может быть только в Англии, этот процесс совершается естественнь путём взаимных и добровольньх уступок со стороны самих сословий; в остальных он происходит под непосредственною опекою центральной государственной власти, уничтожающей привилегии и стремящейся примирить интересы сословий формальны определением их взаимных обязанностей. Сословия, лишаясь своих политических и юридических привилегий и промыленнх монополий, постепенно принимают формы общественных классов, совершенно равных в своих отнотениях к закону, суду и фиску, и только отличающихся мехпу собою общим характером занятий, сосредотачивахих около себя ту или другую группу народонаселения. Их взаимные права и обязанности более и более определяются, но уже не законом, а взаимния свободным менами услуг и труда. Но в процессе уничтожения сословншх привилегий посредством централизуюцей государственной власти, образовалась во всех европейских государствах особенная общественная группа, бюрократия; её деятельность, значение и сила очевидно обусловились степенью взаимных отношени меху сословиям. Раз собранная в одни руки сила и власть не легко покидается; ибо около неё сосредотачиваотся личные интересн, не легко расстащиеся с выгодами, сопряхеннми с властью. Эти личные интересь, получившие I2 
жизнь, хотя и необходимую вследствие врапды сословий, но во всяком случае чулеядную, зависящую от временной необходимости, обращаются в свою очередь в Гнёт для народной деятельности. Труд бюрократии долкен восполнить собою только недостаток самообладания и самоуправления в различнњ группах народонаселения, он не производит никакой ценности, могущей вступить в свободное народное обращение, он не представляет собою никакой специальной отрасли человеческой деятельности умственной или материальной. Но вмешательство бюрократии редко останавливается на рубеже лишь временного соглашения сословнк интересов, оно распространяется далее, захватьвает в свои руки постоянное над ними попечительство и для этого подчиняет частную хизнь целой системе стеснительного контроля и так называемой подведомственности, пагубно действуоцих на развитие науки и промшленности. С другой стороны, бюрократия создаёт в обществе целый, особый класс лодей, которьх ремесло и способы жизни основанн не на свободном признании ценности их труда со стороны прочих членов общества, а на случайнљх отношениях к представителям власти и на случайнш государственнк потребностях времени. Потому бюрократическая деятельность и сама является подле деятельности прочих групп народонаселения монополею. Она не находит, как все прочие отрасли труда, естественного для себя ограничения в свободной конкуренции производящих и потреблякщих; её произведения не принимаются потребителями по свободной рыночнои цене, а отпускахтся им по определённой таксе, образу- 
емой всею совокупностыю расходов государственного управления. Очевидно, что такой промысел весьма шаток и ненадёжен, и потому чем более обтирна группа народонаселения, с ни связанная, тем худшее он имеет влияние на развитие деятельности в обществе. Итак, чем уступчивее относятся мехду собою сословия, чем умереннее они в своих взаимнах требованиях, тем менее они дакт места бюрократии, которая в свою очередь может наступить на них; общее стремление всех сословнњ интересов долхно заключаться в том, чтобы добровольно и своевременно сделать уступки, которые бы пришлось позже сделать недобровольно, через посредничество бюрократии. С другой стороны, прямой интерес государственной власти заклочается в том, чтобы как можно менее наделять сословия привилегиям, которые ей самой придётся в последствии отбирать. Чем менее вмешивается бюрократия в частные интересы, тем менее развивается в обществе потребность ограничивать стеснительность её действий.

Процесс уравнения сословнх преимуществ, политических, юридических, нравственнх и экономических, проявляется в двух видах: отрицательном и положительном. В первом действует государство или орган государственной власти, упраздняя привилегии, освященне законодательством. Второй, самы деятельны, происходит на почве частной жизни народа, когда нравственны и материяльны быт всех классов общества уравнивается успехами образованности и промшленности.

При зрелом обсуддении сословнњ интересов в новейее время мы легко заметим, как далеко ушли современнне классы I4 
общества от первоначальных своих типов, и кан все они находятся в самой тесной взаимной гармонии:

I. Право крови или рождения. Обязательная для кақдого члена общества принадлежность к классу, в котором он рохдён, всюду исчезла в Европе. Право рождения - привилегия для одних классов и тяжкий гнёт для других - было не легко уступлено привилегированными классами. Но оно по необходимости долхно было замениться свободньм избранием занятий. Во-первьх, чисто физиологическое влияние крови тем слабее, чем более распространена образованность; в образованном народе признаки родового происхождения всегда менее резки, чем в народе грубом и диком. Во-вторъх, всякий труд тем более производителен, чем более он соответствует личнњ веусам и способностям трудящегося; мелду тем умственные и материальные условия успешности труда, специальные познания и капитал, в новейшее время приобретаютя несравненно легче чем предде. Публичное воспитание и книгопечатание постепенно освобоқдают человека от деспотического преобладания над ним той нравственной атмосферы, тех условий бнта, посреди которых он родился и провёл первую часть своей жизни. Масса капиталистов постоянно возрастает; всякого рода капиталы сделались чрезвычайно подвилным; они легко переходят из рук, непользующихся ими, в руки людей, умеющих употреблять их производительньм образом. Но если приобретение и накопление капиталов значительно облегчилось в новейпее время, то новейпие формы и системы кредита ещё более упростили наём капиталов или пользованме ими. В әтом 
отнотении без всякого сомнения представляется впереди ещё более блестящая будущность; в настоящую минуту трудно даже определить развитие, которое способен иметь публичный кредит, при успехах общественной нравственности и полном обеспечении внутренней и внешней безопасности лиц и имуществ. Как производительность всякого труда и капитала есть не только личная выгода трудящегося, но и выгода для всего общества, то вообще распределение имуществ и работ в обществе по вкусам и способностям, а не по отношениям роддения, составляет один из главнњх общественных интересов, и мы дейтвительно видим, что таково направление общественной кизни у всех народов преуспеваюих. В-третьих, наконец, нельзя упускать из виду ещё один закон исторического развития общества, могущественно, и едва ли не могущественнее всех других, противодействующий исключительному скопленио человеческих сил около родовьх центров. Чем замкнутее сословны союз, чем менее сословные союзы меняются своими членами, тем скорее истощался внутренние силы сословий. Мы замечаем постоянны упадок родов, размножахщихся исклочительно браками мехпу родственниками. Англииская аристократия, отличахщаяся своей кивучестьо от всех доселе известных аристократия, находится в непрерывном обмене членов с прочими классами народа, в которые переходят всё менъшие снновья лордов, и из которњх постоянно вступат в аристократио женщины и лучшие граддане на всех поприщах деятельности. Этоху последнеху обстоятельству обязана может быть более всего англииская аристокра- 
тия своею силою и своею популярностью. Нравственная атмосфера семейства и всяких бытовых кружков необходимо требует прилива новых личностей, с новыми нравственными элементами, понятиями, преданиями. Во всяком замкнутом крухке людей, тем более в кружке семейном, горизонт понятий быстро суливается и воззрения людей пошлеют. Для движения жизни личной, точно так же как и общественной, нужно постоянное столкновение, смешение, борьба понятий; всякая новая личность вносит в тесный семейный круг некоторый разлад в понятиях и обычаях сложившихся, заставляет отдать себе отчёт в том, что привыкли делать по рутине, без размышления, заставляет кружок обновиться. Столкновение людей и понятий в сфере публичной жизни не так действительно как в семейнои; на улице, в публичном собрании, в политических кругах можно обойти, избегнуть человека, с которым не сходишься в мыслях; в семействе его не обойдёшь и не избегнешь; - не обойдёшь и не избегнешь влияния его мыслей, с которыми во что бы то ни стало приходится бороться или уступить, подчиниться им.

Но каковы бы ни были умственные, грақданские и экономические успехи современного общества, наследство крови далеко ещё не потеряло в нём значения, и родовые и местные предания быта отцов играют в нём ещё весьма большую роль; ими обусловливается первоначальное воспитание; под преимущественнм влиянием роддения созидается судьба человека в более образованњх слоях общества, и под его исклочительным влиянием в массах народньх. При всех других равных об- 
стоятельствах сын крестьянина, каковы бы ни бшли его наклонности к городской хизни, легче остаётся при крестьянском быте, чем переходит к нему сын купца, как ни бшли бы сильны его наклонности к земледельческому труду и как ни бшло бы расстроено коммерческое имущество отца; мы видим дале, как не охотно делается крестьянином дворовыи человек, хотя бы он пользовался несравненно меньшим благосостоянием и независимостью, чем крестьянин. Едё труднее сживается с сельскою жизнью, хотя бы дахе и не крестьянскою, более достаточный горожанин. Как бы то ни было, быт, в котором рохдён человек, кладёт на него особенны отпечаток, создаёт особенни тип лодеи. Итак дахе при неограниченной грапданской свободе перехода из одного класса в другой, естественнше, родовые и бытовые различия ецё долго будут ограничивать свободное развитие личности. На них не следует жаловаться такке как не следует жаловаться на неограниченную оридическую свободу избрания рода жизни и заняти кахдого члена государства. Последняя открывает путь свободному развитио личншх способностеи, обновляет и освежает все классы общества и содеиствует постепенноку перерохденио классов из искусственнх государственных сословий в естественше общественне групп, распределяочиеся по роду заняти и по свободному, естественному призванио кахдой личности. Но, с другой стороны, бытовые и родовые различия слулат естественнм охранительны әлементом для этого процесса перерохдения; они обеспечивают способн существования массы, которая всё-таки состоит из посред- 
ственностей. Массе легче при существующих общественных условиях каждого рода промьшленности, держаться в своих занятиях, нити рождения и предания, чем переходить к ноBbM.

2. Власть. Различные степени власти и различные отнощения сословий к центральной государственной власти составляот также один из элементов во всех сословнњх интересах. Как бы мы ни пытали судьбы власти в истории с основания её у образованных народов, мы должны придти к убеждению, что самая прочная власть есть та, в повиновении которой заключается сознательний, прямои, личный интерес повинующихся. И отвлечённое мпление и для всех осязательные факты доказывают нам, что такая власть самая устойчивая, что она лучше всякой другой обеспечивает порядок в обществе и менее всякой подверлена случайностям насилия и обмана.

Все классы общества имеют целый круг общих для себя интересов; обязательное вмешательство одного сословия в дела другого всегда принимается последним с недоверием, ибо не может быть полезно для его интересов. Межпу тем успех этих интересов важен для всего народа, ибо кақдое не привилегированное сословие, работая для себя, работает для всего народа. Наконец всякая опека одного сословия над другим есть тялесть пля первого; оно всячески старается избежать этой тягости и сохраннет для себя только внешние принаплехности власти, блеск и почёт. Итак всякая государственная привилегия одного сословия над другим подрывает в народе интерес самой власти, ибо созидает власть непрочную 
и несочувственную народу. Самыми лучшими органами власти служат представители самих сословных интересов; можно скорее опасаться беспощадности такой власти, нежели её слабости. В общественной жизни есть много таких сторон, В которых является сопряжение интересов двух и нескольких сословий; тогда и органы власти должны быть правильным смешением нескольких сословна элементов. Можно быть вполне уверенньм, что здесь, на пути свободного избрания, перевес всегда останется на стороне членов общества более образованнах, и поэтому более полезньх для успеха дела. Что бы ни говорили, образованный человек всегда пересилит необразованного; естественное преимущество слишком на стороне первого; но когда образованнй человек для поддерлания своей власти берётся за оружие материальной силы, тогда может взяться за неё и необразованный, и столкновение решается слепьм случаем обмана или внезапного насилия. Если образованный человек, искушеннй таким печальным для себя опытом, постарается, организовать, для своей защитн, материальную силу посредством своих нравственных и умственных сил, причём перевес его над грубою материальною силою необразованного будет вне всякого сомнения, то в таком случае он будет обязан своим превосходством всё-таки не материальной силе, а умственной, вступившей с нею в союз. Но умственне силы могут быть употреблены с большею пользою и успехом на что-либо другое, нехели на организащио насилия, на служение материальной силе. Развитие духа самоуправления в отдельњх классах общества в высшей степени полезно и для 
интересов самой центральной государственной власти. Давая возможность честолюбивым людям удовлетворять своим инстинктам самам безопасным и ни для кого не стеснительным образом, оно притупляет эти властолюбивые инстинкты, всюду распространённые в обществе и столь опасные для общественного спокойствия, оно пресекает это лихорадочное стрекление всех сословий к государственным должностям и почестям, которое мы видим в некоторых странах. Наконец местное самоуправление чрезвычайно сберегает государственные расходн. Чем шире интересы и общественне и политические вопросы, тем больше влияния получают на них представители чисто умственных движений страны, тем с большим могуществом выступают на сцену отдельные личности, соединяющие в себе все отдельные интересы сословий. И во всеобщих народных вопросах интересы всех классов общества должны быть в стройной гармонии; эта гармония особенно легко достигается при монархической власти, которая не основывается преимущественно на одном каком-либо классе общества, а на всех.

3. Имущество. Некоторые роды имущества особенно присвоены известным родам деятельности: так земли для земледелия, денежные капиталы для торговли, дома для фабрик и разных городских промыслов. Потому сословия прехнего времени имели некоторые роды имуцества в своём исклочительном обладании, и приобретение некоторњх родов имущества лицами, не принадлежащими к известному сословию, было иногда вовсе запрещаемо законом, иногда затрудняемо. Так существовали во многих государствах Европы /особенно в Герма- 
нии/ особье рыцарские имения с исключительньм правом приобретения их лишь членами родовьх дворянских фамилий; дома, торговые заведения, лавки могли быть собственносты только членов замкнутьх городских сословий и корпораций. В настоящее время все эти привилегированне имущества почти вовсе исчезли. Промыленное движение века доказало крайною непроизводительность подобньх имуществ и заставило в интересе самих сословий всячески облегчать переходы имуществ из одних рук в другие. Вместе с тем при постепенном перерождении в настоящее время мелких промыслов и ремёсл в формы обширншх прожшленњх предприятий, всякая отрасль труда соединяет в себе несколько родов капитала. Усовершенствованные способы земледелия требуют значительных денехных калиталов, в несколько раз превосходящих ценность земли, механических заведений, лабораторий, библиотек, учёньх коллекций и т.д. Чисто фабричные производства устраиваются в связи с обширнњми поземельнњи владениями. Совершенно новые промыленные предприятия, как например хелезные дороги, сосредотачивают в себе самне разнообразные роды имущества. Но самы существеннй переворот в распределении имуцеств между разнњми классами общества производят современные товарищества или ассоциации капиталистов, которые ехедневно распространяются и готовы охватить собою народное хозяйство и промыпленны мир всех образованных стран. Фориы этих промышленных, коммерческих и кредитных компаний вполне принадлежат нашему времени. Они собирают $к$ нескольким центрах совокупной собственности все возможные роды 
имуцества: земли, дома, денежные капиталы, фабрики, товары, пути и способы сообщения и т.д., и дают посредством акций кақдому отдельному лицу, участвуюцему в обществе, дале при самых ничтожных его средствах, возможность иметь свою долю собственности в нескольких и весьма разнородных имуществах. Таким образом, если бы мы вздумали применить к современным акционерным компаниям понятия об имуществе, как о признаке принадлежности лица к известному классу, то мы чрезвычайно были бы затруднены, куда отнести акционеров какой-нибудь фабрики, торговой компании, банка, когда они в то же время помещики, чиновники, литераторы и т.д. Формы акционернъх компаний ежедневно размножаются, размеры их оборотов возрастают; созидаются компании вроде парихского двикимого кредита, которые обнимают собою целую группу промышленных предприятий, совершенно мехду собою различных и связанных только коллективною собственностью владельцев акций. Итак постепенно водворяюцаяся необходимость уничтожения сословных имущественны привилегий, постепенно увеличиваюцееся соединение нескольких родов имуществ в одном и том же предприятии, вследствие изменения как в характере, так и в организации предприятий, возмущают распределение имуществ в том порядке, как они распределялись мехду категориями сословий старого времени. Но влияние всех этих причин до сих пор ещё далеко не уничтожило вовсе влияния свойств имущества на общественное призвание его владельца. Право наследства, имеощее до сих пор едва ли не самое значительное влияние на 
распределение имуцеств в обществе, сохраняет имущества в известных группах людей, называемых родами. Между тем наследственность имущества есть могущественны рычаг к их производительному употребленио, в руках владельцев, в чём, без сомнения, закпочается и интерес всего общества. Вместе с тем некоторые роды имущества преимуцественно необходимы для того или другого рода деятельности и быта. Таким образом в настоящее время, особенно в странах и народных массах, где преобладает естественное хозяйство, виды имудества слулат некоторым средоточием и потому признаком известных групп общества; так крупные, средние и мелкир - земельные владения дают особенное направление быту их преимущественнњх собственников: помециков, арендаторов, крестьян.

4. Занятия. Собственно разделение занятий есть уже, как сказано выше, основное начало, из которого вцходило расчленение общєства на группы во все времена и у всех народов. Оно остаётся в своей силе и в настоящее время, оно без сомнения останется в силе и в отдалённом будуцем. Разделение занятия совершалось исторически посредством государственнах привилегия, рождения, воспитания, быта, корпораций, власти, имущества; можно указать на перьлобраз таких государственнх сословий в кастах, потом проследить нить предания, затеряннуо в первобытных обществах европейских народов, закрепление сословин узами феодального периода, государственнуло ломку и регламентацио в период централизации, и наконец постепенное освободдение народнои 
деятельности от гнёта государственных попечении. Личность постепенно получает больше влияния и могущества. Но следуя своему свободному развитию, личность, а с нею вместе и разделение общества на группы, всё таки остаются под естественными охранительными влияниями рождения, воспитания, предании, наследия отцов и корпорационного, союзного духа людей, живущих на одном месте и работающих над одним делом. Таким образом остаются в капдом обществе несколько отдельны групп, имеющих в общем направлении своего быта особое общественное призвание.

В настоящее время, европеиские публицисты, более или менее, различают в заладной Европе следующие классы народа, или общественные группи:

I. Аристократия, или дворянство. Сюда принадлежат потомки старых феодальных родов, сохранившие свои имения и частью свои предания; сюда относятся также вообще владельцы обширных поземельнх владении. Мы не говорим здесь об общественном призвании аристократии; этого трудного вопроса мы предполагаем коснуться в особой статье.

2. Средний класс, или достаточное мещанство/bourgeоisie, Bürgerthum/. Этому классу присвоено название третьего сословия /tiers état/, название, запечатлённое в памяти народной событиями французской револоции. Оно называлось третьим, по отношенио к аристократии и духовенству, которое с отделением церкви. от государства потеряло самостоятельное сословное значение и мало-помалу, особенно в странах протестанских, слилось с другими классами общест- 
ва, преимушественно средним. Третье сословие приобрело в истории новейтего времени огромное значение; всё более и более превозмогает оно в разрешении политических вопросов в заладной Европе влияние других классов общества. Оно с чрезвичайн искусством умело овладеть могущественнейими двигателями современного общества: промьлленностыю, свободным книгопечатанием и политическим образованием; эти силы, сделавшиеся необходимым условиями современного просвещения, обращактся в самых верных союзников всякого, кто умеет отнестись к ним с доверием и бодростыю, и делаются самыми опасными врагами тех, кто их не хочет признать. Другие классн общества частью не могли, частью не умели или не хотели взяться за эти силы; они чаще обращаются к иным силам времён отқивших, которые не могут совладать с новыми движениями века. Третье сословие, гордое своими преимуществами, не раз выступало на материке с притязакиями поглотить в себе и в своих интересах все остальные групп общества. Но политическое доктринёрство высшего меманства, не хотевшее видеть того, что с обоих его сторон внросло в историческом прошедтем общества и росло в настоящем, долхно было несколько раз дорого поплатиться за своё самообольщение. Подле третьего сословия есть целые общественњые массы, которжх не долхна упускать из виду никакая политическая система.

3. Крестьянство. Эта общественная группа представляется в настоящее время наименее затронутою двихениями века; она более всех кивёт на почве предания и менее всех 26 
способна изменять устройство своего быта, сообразно с требованиями и прихотями времени. Предания и воззрения в сфере крестьянства иногда кивут и остаются неприкосновенными в течение многих исторических эпох, проходящих над ними. Потому упорство этой массы может иногда явиться недданным камнем преткновения в разньх направлениях исключительно городской политики. Между тем крестьянство есть тот последний исторический резервуар народных соков, которыми обновляются все классы обцества. За ним уле ничего более нет, остаётся только эмиграция в дальние страны.

4. Наконец пролетариат, или, как называют немшы, четвёртое сословие. Этто та именно общественная группа, которая образовалась под исключительньми влияниями всех современньх общественных сил, частью уже разлоливших, частью ещё разлагаюфих состав прежних сословий. Этой группе принадлежат все отверленды прочих классов общества, все силы общества, оторваннке промпленнм и умственнв двихением века от исторических преданий прекних грахданских союзов. ІІотому группа эта весьма пёстрая; она, по вырахенио Риля, ищет себе места в современных западно-европейских обществах, найдёт его подле других классов или окончательно разложит их, и тогда возникнут мохет быть совершенно новые общественные формации.

Я старался представить самй краткий очерк современного положения сословий, преимущественно в заладно-европеиских государствах, но в такой общности, что главные его начала могут быть применены ко всякому градданскому 
обществу, точно так же и к напему.

Отрадно обратиться от печальной картины врахпы сословий в западно-европеиских обществах, особенно во французском, к нашему отечеству. У нас не било тех замкнутьх союзов, которыми ознаменовала себя история западной Европн; не бшло тех блистательнх проявлений корпоративного духа, которне, при всеобщем насилии, обеспечивали развитие личности, на всех поприщах деятельности, и быстро двигали вперёд успехи гражданственности, науки, промышленности и политического самосознания. Но за то у нас нет ни в настоящем, ни в будущем многих затруднения, солидаемах резкими общественнғми гранями. Мы свободно можем воспользоваться промшленным и умственным двихением образованного мира; ему придётся у нас несравненно менее разлагать, чем творить. Как ии богато своими историческими последствиям общественное разложение, как оно ки далеко от оцепенения восточного мира, но общественное созидание сопрғкено с меньшим страданиями для современников, и эта миль не мохет не бить для нас утешительною.

Мы модем указать и в натем обществе на сословия, более или менее соответствуочие западно-европейским, но вследствие исторических и географических причин, исследование которых не составляет нашей задачи, государственные сословнше определения касались преихуественно только внешнеи стороны мизни наших общественньх групп: аминистративнои и фискальной. Эти определения не въелись в самы бнт народа, не подчинили свокм влияниям всо сово28 
купность его понятий, преданий и обычаев; они бродили на поверхности народной жизни. Вспомним, как мало охватывают собою потребности промышленной жизни наши цехи, с какими затруднениями сопряжено было их учреждение, и как мало, там, где они существуют, ими исчерпывается быт и взаимные отношения промшленных классов.Но вместе с тем никак нельзя отрицать, чтобы в нашем народе вовсе не было элементов союзного духа; мы видим огромнне оброчные /помещичьи/ имения, в которых крестьяне достигли, без всякого постороннего вмешательства, самых удовлетворительньх результатов самоуправления, мы видим целые промышленные союзы, охватываюияе собою весьма обширные группы деревень, артели, в которых внутренняя связь и подчинение членов поддерпиваются исключительно внутренним духом товарищества. Но государственные определения сословий, хотя и дали некоторое направление быту их членов, однако нисколько не создали таких разграничений, которые бы не исчезли тотчас из круга народнњх воззрений, при изменении некоторьх условий быта.Отношения крепостного состояния бшли, без всякого сомнения, самою большою привилегиею, дарованною государственною властью одному сословия перед другим и самою резкою гранью, поставленною государственною необходимостыю между классами общества. Но и крепостное состояние не имеет у нас того общественного характера, какой имело оно у большей части народов заладной Европн; оно является у нас совершенно свободны от тех строгих оридических Форм, прав и обязанностей, какие мы находим, например, в 
Германии. Бместе с тем нигде может быть крепостное право не влекло за собою такого материального насилия как у нас, и это естественно при совершенном отсутствии юридических определения.

Частное материальное насилие гнетёт более власти, организованной с помощью юридических гипотез и презумий, но оно легче совлекается и скорее излечивается, как легче излечивахтся последствия ушиба, нежели хронического расстройства. Во всяком случае упразднение крепостного права, не только подчинявшего себе свободное развитие собственно крепостного состояния, но и налагавшего иго сословного разобщения и разграничения на весь народ, в том числе и на само дворянство, должно снять последнее искусственное препятствие к свободному распределенио занятий в России, а с ним и препятствие к свободному распределению групп народонаселения.В последствии мы ближе рассмотрим положение помещичьего и крестьянского класса в этом преобразовании.

Совершенная особенность нашего общества, это-слабое развитие среднего класса, или мецанства. Эта особенность коренится, кажется,в духе всех славянских народов.Никакие усилия правительства не могли создать у нас среднего класса.Особенно ярким примером является Малороссия, где польское правительство употребляло самые энергичные меры в этом направлении. Мы видим, с одной стороны, чрезвычайную близость всего нашего городского народонаселения, за исклочением помещиков и чиновников, особенно массы мелких 30 
мещан, к крестьянству, с другой стороны всё фабричное рабочее народонаселение состоит непосредственно из крестьян. Мы не думаем, чтобы уничтожение крепостного состояния существенно изменило в этом отнотении наш народный быт, в котором сельские и городские промысль, сельский и городской тип являются в таком странном, нигде не существующем кроме как у нас, смешении. Это явление имеет другие причины, более народне, чем крепостное состояние. Освобохдение должно значительно содействовать развитию среднего класса, в котори перейдёт много членов дворянского класса. Но это будет, кажется, особенного рода средний класс.

Вместе с тем у нас почти нет и пролетариата, хотя это єщё не значит, чтоб у нас не было бедности. Не вдаваясь в причины отсутствия у нас пролетариата,-это отвлекло бы нас слипком далеко,-мы заметим только, что пролетариат образуется из элементов, разлагаюих политические сословия, из отверкенцев сословнах союзов. Потому, чем слабее эти сословные сонзы, тем менее материи для образования пролетариата.

Таким образом у нас собственно остаюся две существенные группы: помецики и крестьяне. Но помещик, в своём общественном, нравственном и экономическом значении, есть тот же земледелец, как и крестьянин. Помещичй класс, как и вообще аристократия, есть высшая степень развития крестьянства. Помещик-потенцированный крестьянин, по меткому выраленио Риля. Дећствительно, мы находим везде самое тёплое сочувствие межпу этия әлементами, сочувствие, ка- 
кого нет между высшим мещанством и крестьянами.Крепостное право и вообще все насильственные господские привилегии суть единственное препятствие к свободному развитию и раскрытио этих внутренних сочувственна отношений. Так, где это насильственное господство исчезло рано/как в Англии/, там оба класса кивут в такой дружбе, какой не момет быть между другими сословиями. То же самое непременно долхно быть и у нас, когда помещичий класс перестанет помыплять о своих печальны вотчиннх отношениях, а помслит о своём высоком общественном призвании.

Справедливо видят в помецичьем и крестьянском классах охранительне элементы общества; в городском классе и пролетариях-элементы общественного двиления. У нас первые два класса преобладакот, как в действительности и преобладает у нас, в народе и государстве, охранительный характер. Он опирается на самые естественне условия народного типа и быта, он не нулдается ни в какой искусственной поддерлке. и может расшевелиться разве только для охранения себя от возмущающих народную иизн искусственны охранительных теория, которые, увлекаясь призраками не существующих народнх волнения, ставили бы насильственные препоны великому народному генио.

$$
\text { B. Бе } 3 \text { ○ } 6 \text { p a } 3 \circ \text { в }
$$


Bisher erschienen (im W.Schmitz Verlag, Gießen):

Band 1: $\quad$ Peter Thiergen

Turgenevs "Rudin" und Schillers "Philosophische Briefe".

(Turgenev Studien III)

1980, 66 S., broschiert, DM 19,80

Band 2: Bärbel Miemietz

Kontrastive Linguistik.

Deutsch-Polnisch 1965-1980

1981, 132 S., broschiert, DM 25,-

Band 3: Dietrich Gerhardt

Ein Pferdename

Einzelsprachliche Pointen und die Möglichkeiten ihrer Übersetzung am Beispiel von A.P. Cechovs "Lošadinaja familija". 1982, 69 S., broschiert, DM 20,-

Band 4: Jerzy Kasprzyk

Zeitschriften der polnischen Aufklärung und die deutsche Literatur.

1982, 93 S., broschiert, DM 20.-

Band 5: Heinrich A.Stammler

Vasilij Vasil'evič Rozanov als Philosoph.

1984, 90 S., broschiert, DM 20.-

Band 6: Gerhard Giesemann

Das Parodieverständnis in sowjetischer Zeit.

Zum Wandel einer literarischen Gattung.

1983, 54 S., broschiert, DM 19,-

Band 7: Annelore Engel-Braunschmidt

Hebbel in Rußland 1840-1978.

Gefeierter Dichter und verkannter Dramatiker.

1985, 64 S., broschiert, DM 20,-

Band 8: Suzanne L.Auer

Borisav Stankovićs Drama "Koštana"

Übersetzung und Interpretation.

1986, 106 S., broschiert, DM 20,-

(im Otto Sagner Verlag, München):

Band 9: $\quad$ Peter Thiergen (Hrsg.)

Rudolf Bächtold zum 70. Geburtstag

1987, 107 S., broschiert, DM 22,- 
Band 10: A.S.Griboedov

Bitternis durch Geist

Vers-Komödie in vier Aufzügen. Deutsch von Rudol Bächtold

1988, 101 S., broschiert, DM 20,-

Band 11: Paul Hacker

Studien zum Realismus I.S.Turgenevs

1988, 79 S., broschiert, DM 20,-

Band 12: Suzanne L. Auer

Ladislav Mñačko

Eine Bibliographie

1989, 55 S., broschiert, DM 16,- 